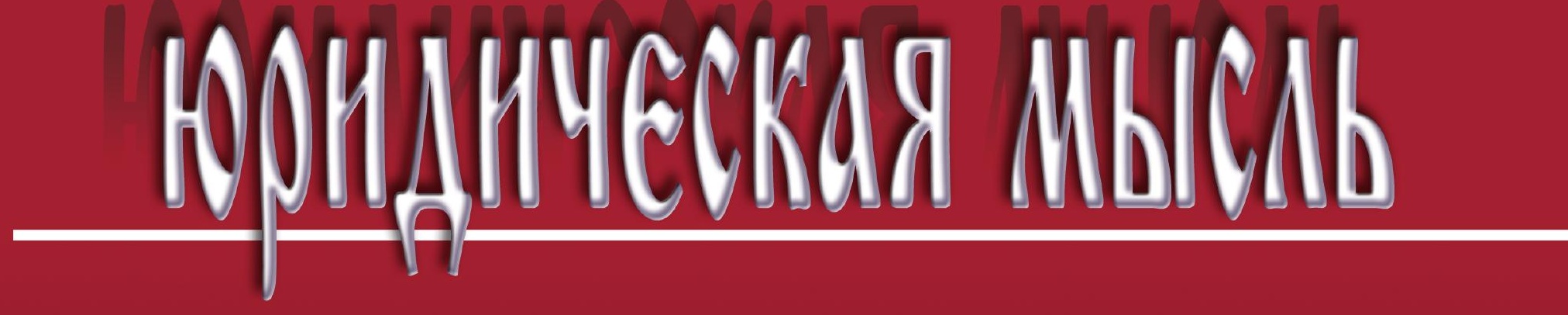

№ 3, 2021

ISSN: $2071-4920$ (Print) ISSN: 2712-7818 (Online) 


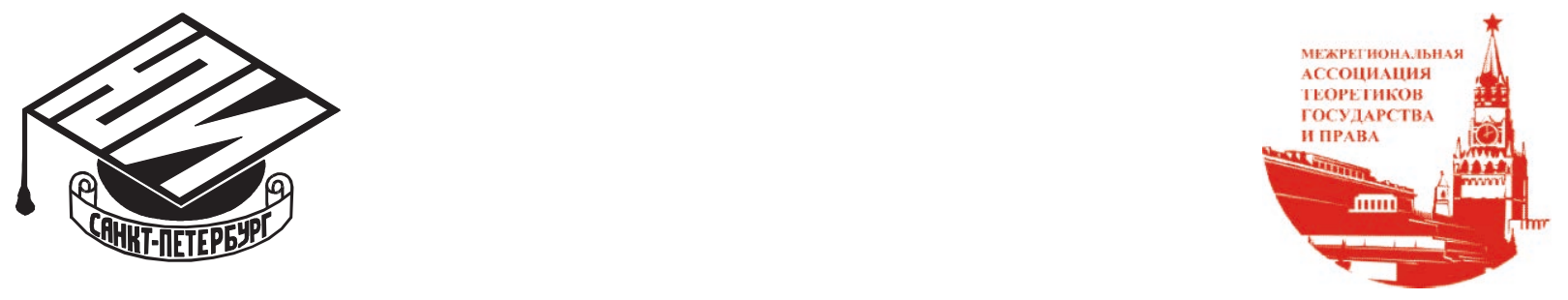

\section{Юридическая МЫС $\Lambda Ь$}

20213 (123)

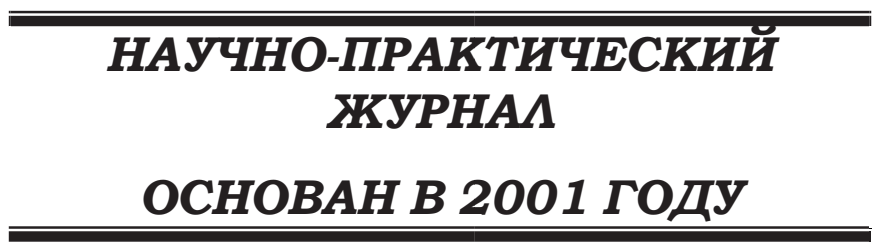

ISSN 2071-4920

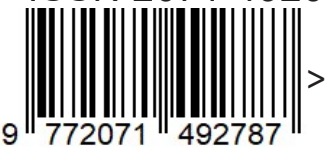

Журнал "Юридическая мысль" с 2010 г. входим

в ПЕРЕЧЕНЬ ведущих рецензируемых научных журналов и изданий,

в которых домжны быть опубликованы основные научные результаты диссертаций на соискание ученой степени доктора и кандидата наук

\section{САНКТ-ПЕТЕРБУРГ}




\section{Учредитель и издатель \\ ЧОУ ВО «Юридический институт» (Санкт-Петербург) \\ Межрегиональная ассоциация теоретиков государства и права \\ ГАавный редактор}

М.Б. Ревнова, ректор ЧОУ ВО “Юридический институт» (Санкт-Петербург), кандидат юридических наук

\section{Заместитель гмавного редактора}

С.А. Комаров, президент Межрегиональной ассоциации теоретиков государства и права,

научный руководитель ЧОУ ВО «Юридический институт» (Санкт-Петербург), доктор юридических наук, профессор,

заслуженный деятель науки и образования РАЕ

Ответственный секретарь редакционной коммегии

А.В. Яковмев, доцент кафедры теории и истории государства и права ЧОУ ВО «Юридический институт" (Санкт-Петербург), кандидат юридических наук

\section{Редакционная коммегия:}

P.н. Дусаев, заведующий кафедрой общеправовых дисциплин юридического факультета Петрозаводского государственного университета, доктор юридических наук, профессор;

Т.ム. Комарова, проректор по науке и инновациям ЧОУ ВО “Юридический институт" (Санкт-Петербург), кандидат юридических наук, доцент;

Б.А. Ревнов, доцент кафедры конституционного и административного права ЧОУ ВО “Юридический институт" (Санкт-Петербург), кандидат юридических наук;

E.B. Середа, профессор кафедры уголовного права и процесса ЧОУ ВО «Юридический институт» (Санкт-Петербург), доктор юридических наук; профессор.

\section{Редакционно-издательский совет:}

С.А. Комаров, президент Межрегиональной ассоциации теоретиков государства и права, научный руководитель ЧОУ ВО “Юридический институт» (СанктПетербург), доктор юридических наук, профессор, заслуженный деятель науки и образования РАЕ, председатель совета;

В.A. Винокуров, профессор кафедры теории и истории государства и прав ФГБУ ВО "Санкт-Петербургский университет ГПС МЧС России", Заскуженный юрист Российской Федерации, доктор юридических наук, профессор, член совета;

C.M. Воробьев, профессор кафедры теории государства и права, международного и европейского права Юридического факультета Академии ФСИН России, доктор юридических наук, профессор, чмен совета;

Ф.X. Гамиев, заведующий кафедрой теории государства и права Института права Башкирского государственного университета, доктор юридических наук, доцент, чиен совета;

А.М. Дроздова, профессор кафедры правовой культуры и защиты прав чемовека Северо-Кавказского федерального университета, доктор юридических наук, профессор, чиен совета;

Е.С.Ч. Ковамьски, директор Российской школы права Юридического факультета Университета Мазарского (UczelniŁazarskiego) в Варшаве, Республика Польша, доктор honoris causa ЧОУ ВО “Юридический институт" (Санкт-Петербург), доктор политических наук, профессор, чмен совета; 
M.E. Kpyк-Ярош (MariaKruk - Jarosz), заместитель декана по вопросам докторантуры Университета Аазарского (Uczelni Łazarskiego) в Варшаве, Республика Польша, доктор honoris causa ЧОУ ВО "Юридический институт" (СанктПетербург), доктор юридических наук, профессор, член совета;

Г.А. Мартьянов, доцент кафедры теории и истории государства и права ЧОУ ВО “Юридический институт" (Санкт-Петербург), кандидат юридических наук, чмен совета;

E.B. Мицкая, заведующая кафедрой уголовного права, процесса и криминамистики Южно-Казахстанского государственного университета им. М. Ауэзова (Респубиика Казахстан), доктор юридических наук, профессор, чиен совета;

н.и. Помищук, вице-президент Мехрегиональной ассоциации теоретиков государства и права, профессор кафедры теории государства и права, международного и европейского права Юридического факультета Академии ФСИН России, доктор юридических наук, профессор, чиен совета;

А.В. Попова, профессор Департамента правового регулирования экономической деятельности ФГОБУ ВО “Финансовый университет при Правительстве РоссийскойФедерации" (Финансовый университет), доктор юридических наук, кандидат фимософских наук, доцент, чиен совета;

Г.С. Скачкова, зав. сектором трудового права и права социального обеспечения ФГБУН "Институт государства и права Российской академии наук", доктор юридических наук, профессор, чцен совета;

С.П. Стёпкин, доцент кафедры гражданско-правовых дисциплин Российского государственного социального университета, кандидат юридических наук, доцент, чцен Комиссии Ассоциации юристов России, чцен Совета;

Кари Сюнберг (Kari Synberg), профессор факультета общественных и экономических наук Университета Восточной Финляндии, чмен правления Географического общества Финляндии, доктор honoris causa Юридического института (Санкт-Петербург), доктор географических наук, чиен совета;

Н.А. Фролова, профессор кафедры теории государства и права им. Г.В. Мальцева ФГБОУ ВО «Российская академия народного хозяйства и государственной службы при Президенте Российской Федерации", доктор юридических наук, профессор, чмен совета.

\section{ПОДПИСКА}

в объединенном катамоге Пресса России "Подписка-2021"

Подписной индекс - 82596 (годовая подписка на 2021 г.)

Подписка в Агентстве: по тел. (499) 152-8850 и/или (495) 661-2030, по е-mail: arpk@akdi.ruarpk@bk.ruizdatcat@eg-online.ru

в Каталоге российской прессы "ПОЧТА РОССИИ"

Подписной индекс - 24220 (первое полугодие 2021 г.)

Журнал выходит 4 раза в год

Телефон редакции: (812) 325-98-90

Адрес в Интернете:http:/ / lawinst-spb.ru; http:/ / matgip.ru

E-mail:lawinst-spb@mail.ru; matgip2017@yandex.ru 


\section{Founderand Publisher \\ Law Institute (St. Petersburg) \\ Interregional Association of Theorists of State and Law \\ Chief Editor}

M.B. Revnova, Rector of the Law Institute (St. Petersburg), PhD

\section{Deputy Chief Editor}

S.A. Komarov, President of the Interregional Association of theoreticians of the state and law, scientific director of the Law Institute (St. Petersburg), Doctor of Law, Professor, honored worker of science and education of RAE

\section{Executive Secretary of the Editorial Board}

A.V. Yakovlev, associate Professor of the Department of theory and history of state and law of the Law Institute

(St. Petersburg), PhD

\section{Editorial team:}

R.N. Dusaev, Head of common law disciplines Faculty of Law of Petrozavodsk State University, Doctor of Law, Professor;

T.L. Komarova, Vice-Rector for Science and Innovation of the Law Institute (St. Petersburg), $\mathrm{PhD}$, associate professor;

B.A. Revnov, associate Professor of Department of constitutional and administrative law of law Institute (Saint Petersburg), PhD;

E.V. Sereda, professor of criminal law and procedure of the Law Institute (St. Petersburg), Doctor of Law, Professor.

\section{Editorial and publishing Council:}

S.A. Komarov, President of the Interregional Association of theoreticians of the state and law, scientific director of the Law Institute (St. Petersburg), Doctor of Law, Professor, honored worker of science and education of RAE, Chairman of the Council;

V.A. Vinokurov, Professor of the Department of theory and history of state and rights of the "St. Petersburg University of Emercom of Russia", Honored lawyer of the Russian Federation, Doctor of law, Professor, member of the Council;

S.M. Vorobiev, Professor of the Department of theory of state and law, international and European law, faculty of Law, Academy of the FSIN of Russia, Doctor of law, Professor, member of the Council;

F.H. Galiev, Professor of Theory of State and Law of the Institute of Law of the Bashkir State University, Doctor of Law, associate professor, member of the Council;

A.M. Drozdova, professor of the Department of legal culture and protection of human rights of the North-Caucasus Federal University, Doctor of Law, Professor, member of the Council;

E.S.Ch. Kowalski, Head of the Russian law, professor of legal theory and legal logic, Deputy Dean of Science Faculty of Law of the University of Lazarski (Uczelni Łazarskiego) in Warsaw (Poland), Doctor honoris causa of the Law Institute (St. Petersburg), Doctor of Political Sciences, Professor, member of the Council;

M.E. Kruk-Jarosz (Maria Kruk-Jarosz), deputy dean for doctoral studies of the University of Lazarski (Uczelni Lazarskiego) in Warsaw (Poland), Doctor honoris causa of the Law Institute (St. Petersburg), Doctor of Law, Professor, member of the Council;

G.A. Martianov, associate Professor of the Department of theory and history of state and law of the Law Institute (St. Petersburg), candidate of law, member of the Council; 
E.V. Mitskaya, Head of the Department of Criminal Law, Criminology and process of the South Kazakhstan State University of Auezov (Kazakhstan), Doctor of Law, Professor, member of the Council;

N.I. Polishchuk, vice-president of the Interregional Association of theoreticians of State and Law, Professor of Theory of State and Law, International and European Law Faculty of Law of the Academy of the Federal Penitentiary Service of Russia, Doctor of Law, Professor, member of the Council;

A.V. Popova, a professor of the Department of legal regulation of economic activity, Financial University under the Government of the Russian Federation, Doctor of Law, Ph.D., associate professor, member of the Council;

G.S. Skachkova, Head sector labor law and social security law of the "Institute of State and Law of the Russian Academy of Sciences", Doctor of Law, Professor, member of the Council;

S.P. Stepkin, associate Professor of the Department of civil law disciplines of the Russian state social University, Candidate of law, associate Professor, member of the Commission of the Association of lawyers of Russia, member of the Council;

Soili Nystén-Haarala, Professor of Commercial Law, University of Lapland, Faculty of Law (Republic of Finland), Doctor of Law, Professor, member of the Council;

Kari Syunberg (Kari Synberg), professor of the Faculty of Social and Economic Sciences of the University of Eastern Finland, a board member of the Geographical Society of Finland, the Republic of Finland, Ph.D Geography, Doctor honoris causa of the Law Institute (St. Petersburg), Professor h.c., member of the Council;

N.A. Frolova, a professor of the Department of Theory of State and Law named by G.V. Maltsev of "Russian Presidential Academy of National Economy and Public Administration", Doctor of Law, Professor, member of the Council.

\section{Информация дия авторов:}

Ваши материалы (объемом до 0,6-1,0 усм.-печ. м.) направцяйте по адресу: 199106, Санкт-Петербург, ум. Гаванская, 3. Юридический институт (Санкт-Петербург). Tем. (812) 325-4625. E-mail: lawinst-spb@mail.ru; 119415, г. Москва, ум. Удальцова, дом 19, корп. 1 , оф. 12 МОО «Межрегиональная ассоциация теоретиков государства и права" Tes. (499) 431-5806. E-mail: matgip2017@yandex.ru Каждая статья должна сопровождаться реиензией! Просьба указывать свою должность, ученую степень, звание, фамилию, имя и отчество, почтовый адрес и телефон.

Свидетецьство о регистрации ПИ № 2-4890 от 15 декабря 2000 г.

Формат 80x108/16. Подписано в печать 18.09.2021. Бумага офсетная.

Печать офсетная. Уч.-изд. м. 16,97. Усм. п.м. 10,1. Тираж 100 экз. Заказ №

Отпечатано в типографии "OneBook.ru" ООО "Сам Полиграфист" 109316, г. Москва, Волгоградский проспект, дом 42, корпус 5, "Технополис».

(C) «Юридическая мысль», № 3 (123), 2021 На обложке - фрагмент картины С. Дали "Рафаэлевская голова, разцетающаяся на куски" (1951) 


\section{Юридическая мысль}

\section{1 НАУЧНО-ПРАКТИЧЕСКИЙ ЖУРНАА ОСНОВАН В 2001 ГОДУ

\section{СОДЕРЖАНИЕ}

\subsection{1. ТЕОРЕТИКО-ИСТОРИЧЕСКИЕ ПРАВОВЫЕ НАУКИ}

\section{(12.00.01 - Теория и история права и государства;}

история учений о праве и государстве)

Губанов И.А.

Законодательное регулирование в сфере государственно-частного

партнерства в Испании

Илембетов А.К.

Вызовы обеспечению национальной безопасности Российской Федерации ....

Максимов A.A.

Критика Г.В.Ф. Гегелем философско-правового учения И. Канта о свободе ...

Максимова E.A.

Правовое регулирование государственного и муниципального управцения финансовыми рисками публично-правовых образований

\subsection{4. УГОАОВНО-ПРАВОВЫЕ НАУКИ}

(12.00.08 - Уголовное право и криминомогия; уголовно-исполнительное право)

Гареев М.Ф.

Конфискация имущества как уголовное наказание

Гареев М.Ф.

Государственная идеология как основа предупреждения преступлений

\section{В ПОМОЩЬ ПРЕПОДАВАТЕАЮ}

Бастрыкин А.И.

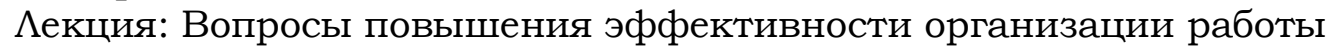

следственных органов Следственного комитета Российской Федерации

\section{ПЕРСОНАМИИ}

Захариев С.И., Комаров С.А., Хабибулин А.Г.

Виктору Петровичу Сальникову исполняется 75 мет 


\section{CONTENT}

\subsubsection{THEORETICAL AND HISTORICAL LEGAL SCIENCES}

\section{(12.00.01 - Theory and history of law and state; history of doctrines about law and state)}

Gubanov I.A.

Legislative regulation in the field of public-private partnership in Spain

Ilembetov A.K.

Challenges to ensuring the national security of the Russian Federation

Maksimov A.A.

Criticism G.V.F. Hegel of the philosophical-legal teaching of I. Kant about freedom

Maksimova E.A.

Legal regulation of state and municipal governance of financial risks of public legal formations

\subsubsection{CRIMINAL SCIENCES}

\section{(12.00.08 - Criminal Law and Criminology; penal law)}

Gareev M.F.

Confiscation of property as a criminal punishment

Gareev M.F.

State ideology as basis for crime prevention

\section{TO HELP THE LECTURER}

Bastrykin A.I.

Issues of increasing the efficiency of organizing the work of investigative bodies of the Investigative Committee of the Russian Federation: Lecture

\section{PERSONNEL}

Zakhartsev S.I., Komarov S.A., Khabibulin A.G.

Viktor Petrovich Salnikov is 75 


\title{
ДЕНИСОВСКИЕ ЧТЕНИЯ
}

VI Международная научно-теоретическая конференция

\author{
"Чемовек-природа, мичность-общество, гражданин- \\ государство в условиях информатизацин и цифровизацин \\ российского общества в интересах устойчивого развития"
}

12-13 октября 2021 года

\section{International Scientific Conference}

\begin{abstract}
"Man-nature, personality-society, citizen-state in the context of informatization and digitalization of Russian society in the interests of sustainable development"
\end{abstract}

\section{2-13 October 2021 года}

Межрегиональная ассоциация теоретиков государства и права, редкомлегии журналов "Теория государства и права", "Юридическая мысль", "Вестник общей и отраслевой теории права", "Современное российское право", "Вестник Института права Башкирского госудрственного университета", "Вестник Костромского государственного университета", "Вектор науки Тоцьяттинского государственного университета", "Миграционное право", "Dilemas contemporaneos-educacion politica y valores" (Мексика) 12-13 октября 2021 года (г. Рязань) в очно-заочном формате проводят VI Международную научно-теоретическую конференцию "Чемовек-природа, Аичность-общество, гражданин-государство в условиях информатизации и цифровизации российского общества в интересах устойчивого развития" посвященную 115-цетию со дня рождения Заслуженного деятеля науки и техники РСФСР, доктора юридических наук, профессора ДЕНиСОВА АНДРЕЯ ИВАНОВИЧА и 70-Аетию со дня рождения Заслуженного деятеля науки и образования РАЕ, доктора юридических наук, профессора КОМАРОВА СЕРГЕЯ ААЕКСАНДРОВИЧА.

K выступлению с докладами приглашаются доктора и кандидаты наук, аспиранты (адъюнкты) и соискатели, студенты, практикующие юристы.

Регистрация 12-13 октября: 9.30-10.30 (московское время), начало работы конференции: 10.30, перерыв: 13.00 - 14.00, окончание работы конференции: 16.00.

Рабочие языки конференции - русский и английский. 
Проезд и проживание иностранными и иногородними участниками оплачиваются и организуются самостоятельно.

Просим Вас подтвердить свое участие в конференции (указав фрорму участия), пройдя электронную регистрацию до 01 октября 2021 года на сайте: www.matgip.ru (Межрегиональная ассоциация теоретиков государства и права) или по эмектронной почте: matgip2017@yandex.ru

Доклады, статьи, сообщения надо направить до 20 октября 2021 г. в электронном виде по адресу: matgip2017@yandex.ru или в печатном виде по адресу: 119415, г. Москва, ум. Удамьцова, дом 19, корпус 1, оф. 12.

\section{Секции конференции}

1. Государственно-правовые воззрения А.И. Денисова на соотношение природы-общества-государства.

2. Научная школа А.И. Денисова о соотношении человека-природы, мичности-общества, гражданина-государства в условиях информатизации и цифровизации российского общества в интересах устойчивого развития.

3. Информатизация и цифровизациия современного общества: вопросы теории и практики.

4. Устойчивое развитие как равновесие трех основных составцяющих: экономический рост, социальная ответственность и экологический баланс.

5. Цели в области устойчивого развития дмя преобразования нашего мира.

6. Нормативно-правовое регулирование в условиях информатизации и цифровизации российского общества.

\section{Российский индекс научного иитирования}

Инфрормация о материалах, опубликованных в журналах по тематике конференции, будет размещена в системе E-library (РИНЦ).

Материалы конференции будут размецены в номере 4 журнала "Теория государства и права" за 2021 год, в других журналах информационных партнеров.

\section{Рассъика журнала и Сертификата участника конферениии}

Рассылка журнала и сборника авторам, заказавшим печатный вариант, вместе с сертификатом, будет производиться централизовано, посредством почты России, простой бандеролью после 10 ноября 2021 года. 


\section{Оформление материалов}

1. Рукопись статьи домжна быть отпечатана через 1.5 компьютерных интервала 14 шрифтом, страницы пронумерованы. Сноски оформляются в виде затекстовых ссылок в соответствии с библиографическими требованиями, размещаются после текста статьи под заголовком "Список митературы". Источники в списке располагаются в соответствии с ГОСТ Р 7.0.52008 «Справки по оформлению списка митературы". При ссылке на конкретный фрагмент текста источника в отсылке указывается порядковый номер и страницы.

Например:

- в тексте [8, с. 15];

- в затекстовой ссылке: Комаров С.А. Общая теория государства и права: учебник. 9-е изд. - М.: Изд-во Юрайт, 2019. - 506 с.

2. Объем статьи не должен превышать 10 машинописных страниц.

3. Статья(и) аспиранта(ов) должны быть согласованы с их научным руководителем (руководителями).

4. Статьи, направленные авторам на доработку, подлежат возврату в редакцию в рекомендованный срок с производственными изменениями и исправцениями в тексте.

5. Статьи на русском (английском) языке можно направить также на электронный адрес редакции журнала "Теория государства и права" matgip2017@yandex.ru

6. Фотография автора (5 x 6 см.) - по жеманию.

7. В случае несоблюдения настоящих требований по оформлению пубмикации редакция оставцяет за собой право ее не рассматривать.

\section{REQUIREMENTS \\ for Manuscripts, submitted for publication}

1. The text of article should be printed in 1.5 computer range 14 print. Pages must be numbered. Footnote out in the form of references in the endnotes according to bibliographic requirements are placed after the text of the article under the heading "References". Sources in the list are arranged in accordance with GOST R 7.0.5-2008 "Help on registration list of the literature". When referring to a specific piece of text is-sending source in the serial number and pages. For example:

- In the text [8, p. 15].

- In transtextual link: Komarov S.A. The general theory of state and law: the textbook. 9-th ed. - M.: Publishing House "Yurait", 2019. - 506 pp.

2. The paper should not exceed 10 printed pages.

3. Articles, aimed authors for revision shall be returned to the editor in the recommendatory term production changes and corrections in the text (in the form of imprint) and an electronic copy.

5. Article sent by E-mail: matgip2017@yandex.ru

6. Photo of author $5 \times 6$

7. In the case of non-compliance with these requirements by designing the publication editors reserve the right not to consider it. 


\section{Стандарты оформиения материалов}

1. Материал должен быть подготовцен и отправцен на модерацию в формате .doc мибо .docx;

2. Языки материала - русский мибо ангмийский;

3. Размер страницы - A4, ориентация - «Книжная";

4. Поля страницы: Верхнее - 20 мм, Нижнее - 20 мм, Правое - 20 мм, Аевое - 30 мм.;

5. Отступ первой строки абзаца слева (красная строка) - 1,25 см;

6. Первый абзац - ФИО авторов (выравнивание по правому краю);

7. Второй абзац - Наименование организации, страна, город, электронный адрес (E-mail) (выравнивание - по правому краю);

8. Третий абзац - Помное название темы статьи (выравнивание по центру, начертание полужирное) на русском и английском языках;

9. Далее аннотация и ключевые слова на русском языке и английском языках;

10.Затем текст статьи (междустрочный интервал - 1,5 строки, выравнивание - по ширине, без переносов);

11.Во всем тексте статьи шрифт - Times New Roman, размер шрифта - 14 кегль;

12. Библиографический список используемой митературы: каждый источник должен быть написан с новой строки. Необходимо указать полное наименование источника и авторов.

13. Как только статья будет проверена рецензентами и рекомендована к публикации, автор получит сообщение о принятии материала и стоимости организационного взноса с указанием на порядок и реквизиты оплаты. 


\section{ОРГАНИЗАЦИОННЫЙ КОМИТЕТ КОНФЕРЕНЦИИ}

1. Полищук Николай Иванович - председатель оргкомитета конференции, вице-президент Межрегиональной ассоциации теоретиков государства и права, профессор кафедры теории государства и права, международного и европейского права Академии права и управления ФСИН России, профессор кафедры теории и истории государства и права Юридического института (Санкт-Петербург), доктор юридических наук, профессор (г. Рязань, Россия).

2. Кари Сюонберг - сопредседатель оргкомитета конференции, помощник члена парламента Финляндии, Президент географического общества Финияндии, Ph.D.Geography, Dr.h.c. of Law (г. Хельсинки, Финляндия), доктор honoris causa Частного образовательного учреждения высшего образования "Юридический институт" (Санкт-Петербург).

3. Галиев Фарит Хатипович - сопредседатель оргкомитета конференции, профессор кафедры теории государства и права Института права ФГБОУ ВО “Башкирский государственный университет", гл. редактор журнала "Вестник Института права Башкирского государственного университета", доктор юридических наук, доцент (г. Уфа, Россия).

4. Дроздова Амександра Михаймовна - сопредседатель оргкомитета конференции, профессор кафедры правовой культуры и защиты прав чемовека Юридического факультета Федерального государственного автономного образовательного учреждения высшего образования "СевероКавказский федеральный университет" (г. Ставрополь, Россия), доктор юридических наук, профессор.

5. Комарова Татьяна Мьвовна - сопредседатель оргкомитета конференции, проректор по науке и инновациям Юридического института (Санкт-Петербург), ответственный секретарь Межрегиональной ассоциации теоретиков государства и права, заместитель главного редактора журнала "Law and Power", кандидат юридических наук, доцент (г. Москва, Россия).

6. Кузьмин Игорь Амександрович - сопредседатель оргкомитета конференции, доцент кафедры теории и истории государства и права Иркутского юридического института (филиала) федерального государственного казенного образовательного учреждения высшего образования "Университет прокуратуры Российской Федерации", кандидат юридических наук, доцент (г. Иркутск, Россия).

7. Хабибумин Амик Галимзянович - сопредседатель оргкомитета конференции, заведующий кафедрой финансовых и экономических расследований ВШГА (факультет) МГУ им. М.В. Аомоносова, профессор кафедры теории государства и права и политологии Юридического факультета МГУ им. М.В. Аомоносова, гл. редактор журнала "Миграционное право", заслуженный юрист Российской Федерации, доктор юридических наук, профессор (г. Москва, Россия). 
8. Ревнова Мария Борисовна - сопредседатель оргкомитета конференции, учредитель Частного образовательного учреждения высшего образования "Юридический институт" (Санкт-Петербург), главный редактор журнала "Юридическая мысль", кандидат юридических наук (г. СанктПетербург, Россия).

9. Спирин Миханц Юрьевич - сопредседатель оргкомитета конференции, доцент кафедры теории и истории государства и права и международного права Юридического института ФГАОУ ВО “Самарский национальный исследовательский университет имени академика С.П. Королева", гл. редактор журнала "Вестник общей и отраслевой теории права", кандидат юридических наук, доцент (г. Самара, Россия).

10. Груздев ВАадисмав ВАадимирович - проректор по науке Костромского государственного университета, гл. редактор журнала "Вестник Костромского государственного университета", доктор юридических наук, профессор (г. Кострома, Россия).

11. Комаров Вцадимир Сергеевич - главный редактор журнала "Теория государства и права", кандидат юридических наук (г. Москва, Россия).

12. Ирошников Денис ВАадимирович - доцент кафедры "Теория права, история права и международное право" Юридического института Российского университета транспорта (МИИТ), кандидат юридических наук, доцент (г. Москва, Россия).

13. Аипинский Дмитрий Анатомьевич - профессор кафедры теории государства и права Института права Тольяттинского государственного университета, зам. гл. редактора журнала "Вектор науки Тольяттинского государственного университета", доктор юридических наук, профессор (г. Тольятти, Россия).

14. Мицкая Елена Вцадимировна - профессор кафедры уголовного права и криминологии Южно-Казахстанского государственного университета им. М. Ауэзова (г. Шымкент, Республика Казахстан); профессор кафедры конституционного и административного права Частного образовательного учреждения высшего образования "Юридический институт" (Санкт-Петербург), доктор юридических наук, профессор.

15. Сальников Виктор Петрович - Президент Фонда поддержки науки и образования в области правоохранительной деятемьности "Университет", гАавный редактор журнала "Юридическая наука: история и современность", заслуженный деятель науки Российской Федерации, доктор юридических наук, профессор (г. Санкт-Петербург, Россия).

16. Ковамьский Ежи Сергей Чеславович - заведующий кафедрой российского права, профессор кафедры теории права и юридической могики, заместитель декана по науке Юридического факультета Аазарски университета (г. Варшава, Республика Польша), кандидат юридических наук, доктор PhD in Law, профессор. 


\section{Информационные партнеры}
Журнал
«Теория
государства
и права"

Вестник

Костромского государственного университета

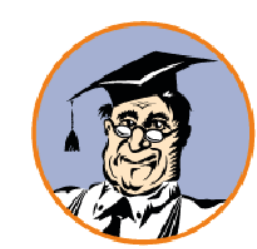

Компания «Консультант-

ПАюс"

\author{
Журнал \\ «Юридическая \\ наука" \\ Журнал \\ "Современное рос- \\ сийское право"
}

Журнал «Вестник общей и отраслевой теории права"

$$
\begin{gathered}
\text { Журнал } \\
\text { «Миграционное } \\
\text { право» }
\end{gathered}
$$

Журнал

"Вектор науки Тоцьяттинского государственного университета"

Серия: Юридические науки
Журнал

«Вестник

Института права

БашГУ"

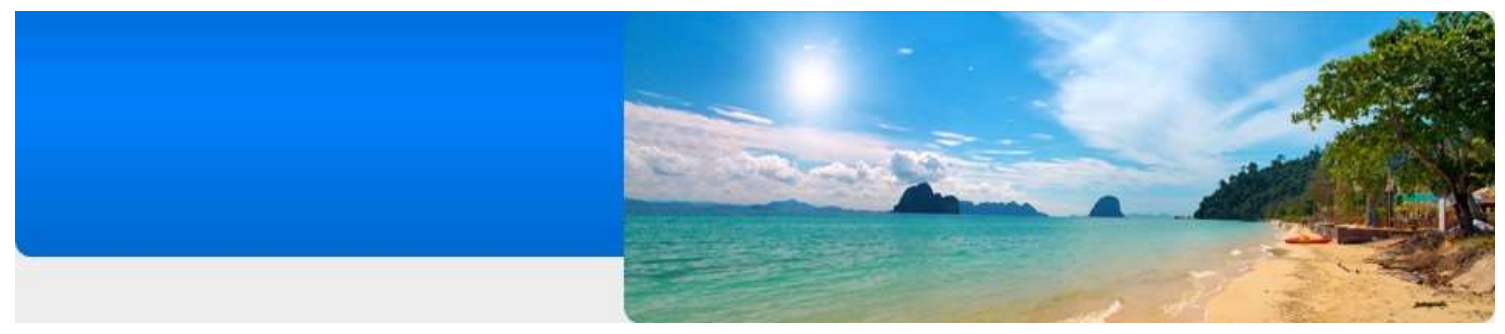

Журнал

«Dilemas contemporaneos-educacion politica y valores» (Мексика) 


\title{
5.1.1. ТЕОРЕТИКО-ИСТОРИЧЕСКИЕ ПРАВОВЫЕ НАУКИ
}

\author{
(12.00.01 - Теорня н нсторня права \\ н ГОсУАарстВа; нсторня үченнй \\ - праве н госуадартве)
}

Удк 340

ББК 67.0

DOI: 10.47905/MATGIP.2021.123.3.003

\author{
Законодательное регуһнрованне в сфере \\ ГОСУААрСТВенно-частноГО ПарТнЕрСТВа \\ в Испаннн
}

И.А. Гуванов*

\begin{abstract}
Аннотация. В статье рассматриваются вопросы определения уровня правового регулирования и особые формы реализации проектов на основе механизма государственно-частного партнёрства (ГЧП) на примере концессии в сфере обращения с твердыми коммунальными отходами в Испании.
\end{abstract}

КАючевые слова: государственно-частное партнерство, концессия, соглашение, финансирование, усмуги.

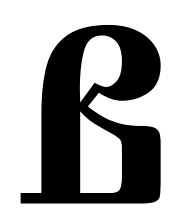

Испании государственно-частное партнерство (далее - ГЧП) - это не просто правовой механизм, а вид государственной политики или способ государственного регулирования, который включает взаимодействие между государством и частным партнером.

Целью данного взаимодействия явцяется создание, финансирование и управление государственной инфраструктурой, включая комплекс зданий, сооружений, оборудования и инженерных сетей.

Разцичные виды договоров/согмашений ГЧП регулируются общими нормами права для юбых видов проектов, сфер оказываемых услуг или типов инфраструктурных объектов.

Соглашения, которые основаны на принципах ГЧП, в Испании регумируются Законом о договорах в государственном секторе (Закон 9/2017) [1]. Этот закон охватывает 2 вида согмашений ГЧП: «концессионные соглашения на работу" и "концессионные соглашения на оказание услуг" (далее концессия на работы, концессия на услуги, соответственно).

* Губанов Илья Андреевич, Руководитель Юридического департамента публичноправовой компании по формированию комплексной системы обращения с твёрдыми коммунальными отходами "Российский экологический оператор", кандидат юридических наук. E-mail: i.gubanov@reo.ru 
Концессии на работы по испанскому законодательству являются соглашениями, по которым концессионер реализует государственный инфраструктурный проект за свой счет и поцучает доход за эксплуатацию объекта (сбор платы с потребителей), принимая на себя все риски, в течение всего срока действия согмашения.

Такой вид соглашения чаще всего используется на практике для новых категорий проектов таких, как:

- проекты, которые требуют участия частного партнера в разработке проекта;

- проекты, по которым частный партнер управляет инфраструктурой, необходимой государственным учреждениям, которые используют объект инфраструктуры непосредственно дия оказания услуг, предоставмяемых государством гражданам (используя собственные средства), а не частным мицам;

- проекты, в которых частный партнер получает плату за оказываемые услуги не напрямую от потребителей, а от государства (плата происходит как за количество потребителей, получающих услугу, "плата за спрос", так и за доступность объекта инфраструктуры для государства, "плата за доступность").

Концессия на услуги - это договор, по которому концедент передает

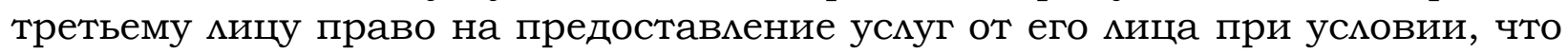
концессионер принимает на себя все операционные риски.

Концессия на услуги отличается от обычного соглашения об оказании услуг рисками, которые принимает на себя концессионер. При передаче ответственности за операционные риски частному партнеру Законом о договорах в государственном секторе такое соглашение определяется как концессионное. С другой стороны, если передача ответственности за риски не происходит, соглашение определяется как обычное соглашение на оказание услуг, а не концессионное.

Также стоит отметить, что существует подкатегория концессий на усмуги, которые заключаются на муниципальном уровне. Предметом соглашений данной подкатегории явцяется предоставление государственных усмуг компаниями с государственным участием.

Компания с государственным участием - это вид ГЧП, при котором компания создается посредством соглашения между частным и публичным партнерами и выступает на стороне публичного партнера, обладающего признаками концессионера в части прав и обязанностей. Компании с государственным участием имеют дминную историю в испанском законодательстве в предоставлении государственных услуг на местном уровне.

На текущий момент в Испании нет отдемьного органа, регулирующего сфреру ГЧП.

В октябре 2015 г. правительство страны создало Национальную службу оценки (далее - Служба) дмя совершенствования качества инвестиций, осуществляемых государственными органами. Служба проводит оценку возможности реализации проекта в рамках государственного договора, учитывая правила бюджетного планирования. Служба также может оказы- 
вать содействие регионацьному и местному правительствам. Однако полномочия Службы еще не были закреплены законодательно, поэтому она не осуществляет свою деятельность. На сегодняшний день Служба не регулируется законом как институт ГЧП, созданный дмя развития преимуществ ГЧП или сбора и улучшения практик применения ГЧП.

Также, Законом о договорах в государственном секторе (Закон 9/2017) [1] были утверждены Комитет взаимодействия по договорам в государственном секторе и Служба контроля за договорами в государственном секторе; обе структуры отвечают за контроль над деятельностью государственных единиц в рамках государственных договоров и за координацию определения критериев оценки.

Испания, являясь унитарным государством, характеризуется высокой степенью децентрализованности, состоит из 50 провинций, входящих в 17 автономных сообществ (регионов) с собственными органами власти, а также полномочиями в части законодательства. Вместе с правительствами национального и регионального уровней Конституцией Испании предоставляется часть административной власти местным органам вцасти.

Органы власти Испании разделяются на три уровня: центральное, региональное и местное правительства и относящиеся к ним государственные учреждения.

Все три уровня имеют различные и то же время парамлельные и скоординированные полномочия.

Что касается сферы обращения с твердыми коммунальными отходами (далее - ТКО) согласно Конституции Испании центральный государственный орган власти обладает исключительной компетенцией в согласовании основного законодательства по защите окружающей среды в то время, как региональные власти имеют полномочия по установцению допоцнительных правил защиты, в дополнение к основной компетенции по исполнения мер, предусмотренных законодательством дия защиты окружающей среды.

К примеру, Государственный закон № 22/2011 от 28 июля об отходах и загрязнении почвы [2] утверждает основной порядок обращения с отходами, применимый в Испании, и регулирует, в том числе, компетенции региональных и муниципальных властей в части обращения с отходами и предусматривает обязательства дмя муниципалитетов по согласованию распоряжений, которые соответствуют данному закону.

Согласно указанному распределению полномочий иентральная власть отвечает за разработку национальной стратегии в сфере обращения с ТКО; определение минимальных показателей снижения уровня накопления ТКО, a также подготовку дия утилизации, рециклинга и иных обязательных форм рекуперации отдельных видов ТКО; согласование ввоза и вывоза TKO из стран, не входящих в ЕС, и проведение экспертиз и разрешительных процедур, необходимых дия вышеупомянутых ввоза и вывоза; выполнение функций, возможенных законом № 1013/2006 Европейского Парцамента и Совета Европы от 14 июня 2006 [3], о поставках отходов дмя ввоза и вывоза из стран, не входящих в ЕС, и в условиях, когда Ис- 
пания явцяется транзитной страной; сбор, подготовку и обновление информации, необходимой дмя исполнения обязательств, установленных национальным и европейским законодательством, международными соглашениями или иными другими обязатемьствами, касающимися пуб$\Lambda$ ичной информации.

Региональная власть отвечает за разработку региональных программ по предотвращению накопления отходов и региональных стратегий обращения с отходами; согласование, проведение мониторинга, экспертизы и выдача разрешений на деятельность, связанную с производством и обращением с отходами; ведение реестра информации о производстве и обращении с отходами в рамках компетенции; предоставцение разрешений на ввоз и вывоз отходов из стран ЕС в соответствии с законом № 1013/2006 Европейского Парламента и Совета Европы от 14 июня 2006 [3], о поставках отходов, а также на перевозку на территории региона, а также на экспертизы и, в случае необходимости, иных разрешений, необходимых дмя вышеупомянутых перевозок; проведение мониторинга и экспертиз, а также выдача разрешений в части компетенции.

мунииипалитеты в обязательном порядке отвечают за сбор, перевозку, обращение с отходами, образованными физическими и юридическими мицами в порядке, предусмотренном федеральным и региональным законодательством и правицами расширенной ответственности производителей. Исполнений данных обязательств может проводиться независимо или совместно с другими муниципалитетами; проведение мониторинга и экспертиз, а также выдача разрешений в части компетенции.

Дополнительно мунииипалитеты могут разрабатывать программы по предотвращению накопления отходов и обращению с отходами в части компетенции; участвовать в процессе обращения с коммерческими неопасными отходами и отходами домашних хозяйств, образованных на производстве, в соответствии с порядками и независимо от того, что производители данных отходов могут самостоятельно их пустить в обращение.

Когда муниципалитеты создают собственные системы обращения с отходами, они могут обязать производителей пользоваться данной системой в опредеменных случаях, надлежащим образом подтвержденными и основанными на параметрах достижения более высокого уровня эфффективности в обращении с отходами.

Посредством выпуска распоряжений обязать производителей или иных держателей опасных видов ТКО ими отходов, обладающих свойствами, которые усложняют применение мер, направленных на устранение или снижение таких свойств, ими захоронение вышеупомянутых отходов в надмежащем виде и местах.

Осуществлять деятельность по обращению с отходами напрямую или в дый муниципалитет может осуществлять такую деятельность как самостоятельно, так и совместно с разцичными муниципалитетами.

В Испании обращение с ТКО происходит как на объектах, включающих только процесс обработки отходов, так и на комплексных объектах. 
После вступления в силу закона № 11/1997 об упаковке и отходах упаковки [4] можно разцичать две фрормы обращения с ТКО в зависимости от объектов, которые используются в процессе обращения с отходами.

Дия бумаги, картона, стекла и строительных отходов существуют разные объекты дмя первичной обработки и дмя конечных процессов обращения с TKO.

Дия всех остальных видов ТКО обращение с отходами осуществляется на комплексных объектах, которые включают обработку, компостирование, энергетическую утилизацию, захоронение.

Целями сферы обращения с ТКО в Испании, закрепленными существующим законодательством, являются, во-первых, основные цели, касающиеся TKO (к 2020 г. уровень подготовки ко вторичному использованию и переработке таких отходов, как бумага, металц, пластик, стекло, органические отходы и иные перерабатываемые отходы, должен быть увеличен до 50\% (минимум) от общего объема таких отходов) и, в-вторых, специальные цеми дия строительных отходов.

Начиная с 5 марта 2006 г. от 25\% до 45 \% от общего объема массы упаковочных материалов, входящих в состав отходов упаковки, должны быть переработаны, причем объем переработки каждого вида упаковочного материала должен составлять не менее 15\% от общей массы.

Не позднее 31 декабря 2008 г. и в последующие годы объем утилизации отходов упаковки должен составлять не менее $50 \%$ и не более 65 \%.

Не позднее 31 декабря 2008 г. достигнуты следующие минимальные показатели достижения уровня переработки по объему массы следующих материалов, входящих в упаковочные отходы: 60\% - стекло; 60\% - бумага и картон; 50\% металц; 22,5\% - пластик (только переработанный пластик) и $15 \%$ - древесина.

Стоит отметить, что в настоящий момент существуют три новых директивы ЕС в Испании (как и в других странах ЕС):

- Директива 2018/851 Европейского Парламента и Совета Европы от 30 мая 2018 г., вносящая изменения в директиву 2008/98/ЕС об отходах [5];

- Директива 2018/852 Европейского Парламента и Совета Европь от 30 мая 2018 г., вносящая изменения в директиву 94/62/ЕС об упаковке и отходах упаковки [6];

- Директива 2018/850 Европейского Парламента и Совета Европы от 30 мая 2018 г., вносящая изменения в директиву 1999/31/ЕС о полигонах захоронения отходов [7].

В соответствии с этими новыми директивами страны-участницы ЕС должны выполнить следующие цели и задачи.

Новые правила для ТКО в иелом.

- Уровень подготовки к вторичному использованию и переработке отходов должен увеличиться не менее, чем до 55\% от общей массы отходов, к 2025 г.

- Уровень подготовки к вторичному использованию и переработке отходов должен увеличиться не менее, чем до 60\% от общей массы отходов, к 2030 г. 
- Уровень подготовки к вторичному использованию и переработке отходов должен увеличиться не менее, чем до 65\% от общей массы отходов, к 2035 г.

Новые правила для строительных отходов.

- Страны-участницы домжны предпринимать меры для развития выборочного сноса с целью устранения и безопасного обращения с опасными веществами и облегчить процессы вторичного использования и высококачественной переработки по средствам выборочного устранения материалов, а также обеспечить создание сортировочных систем для отходов строительства, как минимум для дерева, минеральных фрракций (бетон, кирпич, плитка и керамика, камни), метамла, стекла, пластика и гипса.

Новые правила для упаковочных отходов.

- Не менее 65\% массы всех упаковочных отходов будут переработаны не позднее, чем 31 декабря 2025 г.

- Не позднее 31 декабря 2025 г. будут достигнуты следующие минимальные показатели достижения уровня переработки по объему массы следующих материалов, входящих в упаковочные отходы (50\% - пластик; 25\% древесина; 70\% - черные метам^ы; 50\% - алюминий; 70\% - стек^о; 75\% бумага и картон).

- Не менее 70\% массы всех упаковочных отходов будут переработаны не позднее, чем 31 декабря 2030 г.

- Не позднее 31 декабря 2030 г. будут достигнуты следующие минимальные показатели достижения уровня переработки по объему массы следующих материалов, входящих в упаковочные отходы (55\% - пластик; 30\% древесина; 80\% - черные метам^ы; 60\% - алюминий; 75\% - стекло; 85\% бумага и картон).

Новые правила для захоронения ТКО на полигонах предусматривают снижение уровня захоронения ТКО до $10 \%$ и менее от общей массы к 2035 г.

Следует отметить, что указанные показатели не достижимы без модернизации существующих подходов к развитию товарных рынков, социальной и экомогической ответственности бизнеса.

В настоящее время многие страны уделяют все больше внимания вопросам защиты и сохранения окружающей среды через внедрение новых принципов производства и потребления.

Испания продолжает реализацию экологической политики через принятие руководящих документов, таких как Испанская стратегия замкнутой экономики (далее - Стратегия) [8].

Стратегия устанавливает ряд целей на 2020-2030 годы, которые, среди прочего, позволят сократить на 30\% национальное потребление ресурсов и на 15\% сократить образование отходов (по сравнению с 2010 годом); способствует усициям Испании по переходу к устойчивой, декарбонизированной, ресурсоэффективной и конкурентоспособной экономике; внедряет формы последовательных трехлетних планов действий, предусматривающих конкретные меры по обеспечению циркулярной экономики.

Другие направления касаются экологических государственных закупок или изменения климата. 
Как и в прошлом, наиболее важными областями и тенденциями в области эко-инноваций явцяются управцение отходами, эко-дизайн, зеленая инженерия, переработка отходов, энергоэффективность, устойчивое строительство, эффективность использования воды и городские водные системы. Движущие силы дмя экологических инноваций включают импульс, который имеет экологическая политика в настоящее время, и который может ускорить реализацию политики замкнутого цикла в Испании.

Кроме того, у зеленой экономики есть неиспользованный потенциал дмя создания рабочих мест и преобразования экономической структуры страны.

В то же время, барьерами дмя эко-инноваций остается недостаточная поддержка со стороны политической и регулирующей сфер. Отсутствие финансирования для реализации и поддержки более замкнутых инициатив, а также недостаточная осведомленность граждан являются серьезными препятствиями для достижения указанных целей и дальнейшего устойчивого развития.

Учитывая изложенное, немаловажным фактором достижения Испанией поставленных экологических целей будет усимение роли механизмов ГЧП при реализации инвестиционных проектов, в том числе, в сфере обращения с ТКО.

\section{Бибинографический список}

1. Закон о договорах в государственном секторе (Закон 9/2017) //https:// www.boe.es/eli/es/1/2017/11/08/9

2. Государственный закон № 22/2011 от 28 июля об отходах и загрязнении почвы //https://www.boe.es/eli/es/1/2011/07/28/22

3. Закон № 1013/2006 Европейского Парламента и Совета Европы от 14 июня 2006 // https://www.boe.es/buscar/doc.php?id=DOUE-L-2006-81366

4. Закон № 11/1997 об упаковке и отходах упаковки // https://www.boe. es/eli/es/1/1997/04/24/11

5. Директива 2018/851 Европейского Парламента и Совета Европы от 30 мая 2018 г. //https://eur-lex.europa.eu/eli/dir/2018/851/oj

6. Директива 2018/852 Европейского Парламента и Совета Европы от 30 мая 2018 г. // https://eur-lex.europa.eu/eli/dir/2018/852/oj

7. Директива 2018/850 Европейского Парламента и Совета Европы от 30 мая 2018 г. //https://eur-lex.europa.eu/legal-content/LV/TXT/?uri=CELEX\% 3A32018L0850

8. Испанская стратегия замкнутой экономики //https://circulareconomy. europa.eu/ platform/ en/ strategies/ espana-circular-2030-new-circular-economystrategy-futurosostenible-spain

Дия цитирования: Губанов И.А. Законодательное регулирование в сфере государственно-частного партнерства в Испании: статья // Юридическая мысль. - 2021. - № 3 (123). C. $15-21$.

DOI: $10.47905 /$ MATGIP.2021.123.3.003 


\section{Legislative regulation in the field public-private partnership in Spain}

Ilya A. Gubanov *

Annotation. The article discusses the issues of determining the level of legal regulation and special forms of project implementation based on the mechanism of public-private partnership (PPP) on the example of a concession in the field of solid municipal waste management in Spain. vices.

Key words: public-private partnership, concession, agreement, financing, ser-

In Spain, public-private partnership (hereinafter - PPP) is not just a legal mechanism, but a type of public policy or a method of government regulation, which includes interaction between the state and a private partner.

The purpose of this interaction is the creation, financing and management of state infrastructure, including a complex of buildings, structures, equipment and engineering networks.

Various types of PPP contracts / agreements are governed by general rules of law for all types of projects, areas of services provided or types of infrastructure facilities.

Agreements that are based on PPP principles in Spain are governed by the Public Sector Contracts Act (Law 9/2017) [1]. This law covers 2 types of PPP agreements: "concession agreements for work" and "concession agreements for the provision of services" (hereinafter - concession for work, concession for services, respectively).

Concessions for works under Spanish law are agreements according to which the concessionaire implements a state infrastructure project at his own expense and receives income for the operation of the facility (collection of payments from consumers), taking on all risks during the entire term of the agreement ...

This type of agreement is most often used in practice for new categories of projects such as:

- projects that require the participation of a private partner in the development of the project;

- projects in which a private partner manages the infrastructure required by government agencies that use the infrastructure facility directly to provide services provided by the government to citizens (using its own funds), and not to individuals;

- projects in which a private partner receives payment for the services provided not directly from consumers, but from the state (payment occurs both for the number of consumers receiving the service, "payment for demand", and for the availability of the infrastructure facility for the state, "Availability fee").

* Gubanov Ilya Andreevich, Head of the Legal Department of a public law company for the formation of an integrated system for the management of municipal solid waste "Russian Environmental Operator", Candidate of Legal Sciences. E-mail: i.gubanov@reo.ru 
A service concession is an agreement under which the grantor transfers to a third party the right to provide services on his behalf, provided that the concessionaire assumes all operational risks.

A service concession differs from a conventional service agreement in terms of the risks that the concessionaire assumes. When transferring responsibility for operational risks to a private partner, the Law on Public Sector Contracts defines such an agreement as a concession agreement. On the other hand, if there is no transfer of responsibility for risks, the agreement is defined as a regular service agreement, not a concession agreement.

It is also worth noting that there is a subcategory of service concessions that are concluded at the municipal level. The subject of agreements in this subcategory is the provision of public services by companies with state participation.

A state-owned company is a type of PPP in which a company is created through an agreement between private and public partners and acts on the side of a public partner with signs of a concessionaire in terms of rights and obligations. Publicly owned companies have a long history in Spanish law in the provision of public services at the local level.

Currently, Spain does not have a separate PPP regulatory body.

In October 2015, the government of the country created the National Appraisal Service (hereinafter referred to as the Service) to improve the quality of investments made by government agencies. The service conducts an assessment of the possibility of implementing a project under a state contract, taking into account the rules of budget planning. The service can also assist regional and local governments. However, the powers of the Service have not yet been enshrined in legislation, so it does not carry out its activities. Today the Service is not regulated by law as a PPP institution created to develop the benefits of PPPs or to collect and improve PPP practices.

Also, the Law on Contracts in the Public Sector (Law 9/2017) [1] approved the Committee for Interaction on Contracts in the Public Sector and the Service for Control of Contracts in the Public Sector; both structures are responsible for overseeing the activities of government units within the framework of government contracts and for coordinating the definition of evaluation criteria.

Spain, being a unitary state, is characterized by a high degree of decentralization, consists of 50 provinces included in 17 autonomous communities (regions) with their own authorities, as well as powers in terms of legislation. Together with the governments of the national and regional levels, the Spanish Constitution gives some of the administrative power to the local government.

The Spanish government is divided into three levels: central, regional and local government and related government agencies.

All three levels have different and at the same time parallel and coordinated powers.

With regard to the field of solid waste management (hereinafter - MSW), according to the Spanish Constitution, the central state authority has exclusive competence in harmonizing the main legislation on environmental protection, while the regional authorities have the power to establish additional protection 
rules in addition to the main competence for the implementation of measures provided for by law to protect the environment.

For example, State Law No. 22/2011 of July 28 on waste and soil pollution [2] approves the basic waste management procedure applicable in Spain, and regulates, inter alia, the competence of regional and municipal authorities in terms of handling with waste and stipulates obligations for municipalities to agree on regulations that comply with this law.

According to the specified distribution of powers, the central authority is responsible for developing a national strategy in the field of MSW management; determination of the minimum indicators for reducing the level of MSW accumulation, as well as preparation for disposal, recycling and other mandatory forms of recovery of certain types of MSW; coordination of the import and export of MSW from non-EU countries, and carrying out examinations and licensing procedures necessary for the aforementioned import and export; fulfilling the functions assigned by the law No. 1013/2006 of the European Parliament and of the Council of Europe of June 14, 2006 [3] on the supply of waste for import and export from non-EU countries, and in conditions when Spain is a transit country; collection, preparation and updating of information necessary for the fulfillment of obligations established by national and European legislation, international agreements or other obligations related to public information.

The regional authority is responsible for the development of regional waste prevention programs and regional waste management strategies; coordination, monitoring, examination and issuance of permits for activities related to production and waste management; maintaining a register of information on production and waste management within the competence; granting permits for the import and export of waste from the EU countries in accordance with the law No. 1013/2006 of the European Parliament and of the Council of Europe of June 14, 2006 [3], on the supply of waste, as well as for transportation on the territory of the region, as well as for ex- permissions and, if necessary, other permits required for the aforementioned transportations; monitoring and examinations, as well as issuing permits in terms of competence.

Municipalities are obligatorily responsible for the collection, transportation, handling of waste generated by individuals and legal entities in the manner prescribed by federal and regional legislation and the rules of extended producer responsibility. The fulfillment of these obligations can be carried out independently or jointly with other municipalities; monitoring and examinations, as well as issuing permits in terms of competence.

Additionally, municipalities can develop programs for waste prevention and waste management in terms of competence; participate in the process of handling commercial non-hazardous waste and household waste generated in production, in accordance with the procedures and regardless of the fact that the generators of this waste may independently put it into circulation.

When municipalities establish their own waste management systems, they can oblige producers to use the system in certain cases, duly validated and based on the parameters for achieving a higher level of efficiency in waste management. 
By issuing orders, oblige producers or other holders of hazardous types of MSW or waste with properties that complicate the application of measures aimed at eliminating or reducing such properties, or disposal of the aforementioned waste in an appropriate form and place.

Carry out waste management activities directly or in any other form provided for by local legislation. Each municipality can carry out such activities both independently and jointly with various municipalities.

In Spain, MSW is handled both at facilities that include only the waste treatment process and at complex facilities.

With the entry into force of Law No. 11/1997 on Packaging and Packaging Waste [4], two forms of MSW management can be distinguished, depending on the facilities that are used in the waste management process.

For paper, cardboard, glass and construction waste, there are different facilities for primary processing and for the final processes of MSW management.

For all other types of MSW, waste management is carried out at complex facilities, which include processing, composting, energy utilization, and disposal.

The goals of the MSW management sphere in Spain, enshrined in the existing legislation, are, firstly, the main goals related to MSW (by 2020, the level of preparation for the recycling and processing of such waste as paper, metal, plastic, glass, organic waste and other recyclable waste should be increased to $50 \%$ (minimum) of the total volume of such waste) and, secondly, special purposes for construction waste.

Starting from March 5, 2006, from 25\% to $45 \%$ of the total weight of packaging materials included in packaging waste must be recycled, and the volume of processing of each type of packaging material must be at least $15 \%$ of the total weight.

Not later than December 31, 2008 and in subsequent years, the volume of disposal of packaging waste must be at least $50 \%$ and not more than $65 \%$.

Not later than December 31, 2008, the following minimum indicators of achieving the level of processing by volume of the mass of the following materials included in packaging waste were achieved: $60 \%$ - glass; $60 \%$ - paper and cardboard; $50 \%$ metal; $22.5 \%$ plastic (recycled plastic only) and $15 \%$ wood.

It is worth noting that there are currently three new EU directives in Spain (as well as in other EU countries):

- Directive 2018/851 of the European Parliament and of the Council of Europe of 30 May 2018, amending the directive 2008/98 / EC on waste [5];

- Directive 2018/852 of the European Parliament and of the Council of May 30, 2018, amending Directive 94/62 / EC on packaging and packaging waste [6];

- Directive 2018/850 of the European Parliament and of the Council of Europe of 30 May 2018 amending Directive 1999/31 / EC on landfills [7].

In accordance with these new directives, EU member states must fulfill the following goals and objectives.

New rules for MSW in general.

- The level of preparation for recycling and waste processing should increase to at least $55 \%$ of the total mass of waste by 2025 . 
- The level of preparation for recycling and waste processing should increase to at least $60 \%$ of the total waste mass by 2030 .

- The level of preparation for recycling and waste processing should increase to at least $65 \%$ of the total mass of waste by 2035 .

New rules for construction waste.

Member States should take measures to promote selective demolition to eliminate and safely handle hazardous substances and facilitate recycling and high-quality recycling through selective disposal of materials, as well as ensure the creation of sorting systems for construction waste, at least for wood, mineral fractions (concrete, brick, tiles and ceramics, stones), metal, glass, plastic and gypsum.

New rules for packaging waste.

- At least $65 \%$ of the mass of all packaging waste will be recycled no later than December 31, 2025.

- No later than December 31, 2025, the following minimum indicators of achieving the level of processing by volume of the mass of the following materials included in packaging waste will be achieved $(50 \%$ - plastic; $25 \%$ - wood; $70 \%$ - ferrous metals; $50 \%$ - aluminum; $70 \%$ glass; $75 \%$ paper and cardboard).

- At least $70 \%$ of the mass of all packaging waste will be recycled no later than December 31, 2030.

- No later than December 31, 2030, the following minimum indicators will be achieved to achieve the level of processing by volume of the mass of the following materials included in packaging waste $(55 \%$ - plastic; $30 \%$ - wood; $80 \%$ - ferrous metals; $60 \%$ - aluminum; $75 \%$ glass; $85 \%$ paper and cardboard).

The new rules for the disposal of MSW at landfills provide for a decrease in the level of MSW disposal to $10 \%$ or less of the total mass by 2035 . It should be noted that these indicators are not achievable without modernization of existing approaches to the development of product markets, social and environmental responsibility of business.

Currently, many countries are paying more and more attention to the issues of protecting and preserving the environment through the introduction of new principles of production and consumption.

Spain continues to implement its environmental policy through the adoption of guidance documents such as the Spanish Closed Economy Strategy (hereinafter referred to as the Strategy) [8].

The strategy sets a number of goals for 2020-2030, which, among other things, will reduce national resource consumption by $30 \%$ and reduce waste generation by $15 \%$ (compared to 2010); contributes to Spain's efforts to move towards a sustainable, decarbonized, resource efficient and competitive economy; introduces the forms of successive three-year action plans that provide for specific measures to ensure a circular economy.

Other areas are related to environmental government procurement or climate change.

As in the past, the most important areas and trends in eco-innovation are waste management, eco-design, green engineering, waste recycling, energy efficiency, sustainable construction, water efficiency and urban water systems. The driving forces for environmental innovation include the momentum that 
environmental policy has today, which can accelerate the implementation of circular policies in Spain.

In addition, the green economy has untapped potential to create jobs and transform the country's economic structure.

At the same time, insufficient political and regulatory support remains a barrier to eco-innovation. Lack of funding to implement and support more self-contained initiatives, as well as lack of awareness among citizens, are serious obstacles to achieving these goals and further sustainable development.

Considering the above, an important factor in the achievement of Spain's environmental goals will be the strengthening of the role of PPP mechanisms in the implementation of investment projects, including in the field of MSW management.

\section{Bibliographic list}

1. Law on Public Sector Contracts (Law 9/2017) //https://www.boe.es/eli/ es $/ 1 / 2017 / 11 / 08 / 9$

2. State law No. $22 / 2011$ of July 28 on waste and soil pollution //https:// www.boe.es/eli/es/1/2011/07/28/22

3. Law No. 1013/2006 of the European Parliament and of the Council of Europe of June 14, 2006 // https://www.boe.es/buscar/doc.php?id=DOUE-L-2006-81366

4. Law No. 11/1997 on packaging and packaging waste // https://www.boe. es/eli/es/1/1997/04/24/11

5. Directive 2018/851 of the European Parliament and of the Council of Europe of 30 May 2018 //https://eur-lex.europa.eu/eli/dir/2018/851/oj

6. Directive 2018/852 of the European Parliament and of the Council of 30 May 2018 // https://eur-lex.europa.eu/eli/dir/2018/852/oj

7. Directive 2018/850 of the European Parliament and of the Council of May 30, 2018 //https://eur-lex.europa.eu/legal-content/LV/TXT/?uri=CELEX\% 3A32018L0850

8. Spanish closed economy strategy//https://circulareconomy.europa.eu/ platform/ en/ strategies/ espana-circular-2030-new-circular-economy-strategyfuturosostenible-spain

For citation: Gubanov I.A. Legislative regulation in the field of public-private partnership in Spain: article // Legal thought. 2021. No. 3 (123). P. 22-27.

DOI: $10.47905 /$ MATGIP.2021.123.3.003

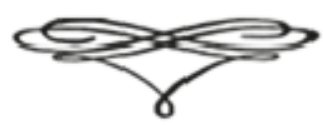




\title{
ВЫЗОВЫ ОБЕСПЕЧЕННю МацНОНААЬНОЙ БЕЗОПаСНОСТН Росснйской Федерацнн
}

\section{Ф.К. ИлемБетов}

\begin{abstract}
Аннотация. В данной статье рассматриваются вопросы, затрагивающие правовое регулирование в сфере обеспечения национальной безопасности Российской Федерации. Дается изложение таких понятий как: предмет, объект, задачи и цели в обеспечении национальной безопасности Российской Федерации, обосновывается идея о том, что национальная безопасность Российской Федерации надёжно обеспечивается только при повышении устойчивости страны к внешним и внутренним угрозам, что без приспособления к экономическим, политическим, военным угрозам современного мира, невозможно обеспечить безопасность государства.
\end{abstract}

К^ючевые смова: национальная безопасность, государственная безопасность, угрозы национальной безопасности, национальные интересы.

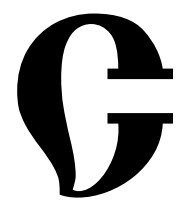

овременный мир по сравнению с историческим миром, развивается быстрыми темпами. В этом играют большую роль экономические, технологические и социальные процессы. Среднестатистический гражданин мюбой страны, интемлектуально не успевает за развитием современных технологий, так как чемовечество, не стоит на месте и стремительно движется вперед, в разных обмастях нашей жизнедеятельности возникают все новые и новые вызовы, в том числе и в области национальной безопасности. Актуальность данной темы так же связана и с последними глобальными проблемами, например, пандемией коронавирусной инфекции COVID-19.

Следует согласиться с Д.В. Ирошниковым в том, что "В обеспечении своей безопасности по природе нуждается каждый живой организм. Согласно пирамиде потребностей по А. Маслоу, безопасность занимает второе место после физиологических потребностей (еда, вода, сон). Потребность в безопасности в свое время явимась причиной объединения мюдей в государства и переросла в его основную цель, о чем упоминали в своих трактатах великие западноевропейские мыслители эпохи Просвещения (Дж. Аокк, Т. Гоббс, Ж.-Ж. Руссо, Ш.ной безопасности явцяется одной из основных функций каждого государ-

* Илембетов Азамат Камилович, студент магистратуры кафедры теории государства и права Института права Башкирского государственного университета. E-mail: azamatilembetov@gmail.com

Научный руководитемь - Комаров Сергей Александрович, профессор кафедры теории государства и права Института права Башкирского государственного университета, доктор юридических наук, професcop. E-mail: SVKomarov2008@yandex.ru 
ства. Оно должно обеспечивать как собственную - государственную безопасность, так и безопасность общества и мичности. Прежде чем рассматривать категорию "национальная безопасность", необходимо опредемиться с термином "безопасность". Под безопасностью принято понимать состояние защищенности того или иного объекта, гарантирующее его устойчивое развитие" [5, с. 643].

K одной из внутренних угроз национальной безопасности Российской Федерации можно отнести демографическую угрозу в силу низкой рождаемости и высокой смертности населения, его вымирания, высокого уровня разводов, алкоголизма, наркомании, распространения опасных заболеваний разного рода, таких как ВИЧ, гепатит, а в данный момент и COVID19. Кроме того угрозой национальной безопасности следует считать так же коррупцию, терроризм, которые особенно выражены в некоторых исламских республиках и т. д.

Все эти серьезные проблемы в совокупности прямо или косвенно влияют на общее благосостояние всей страны и даже человечества, что в свою очередь подразумевает правовое регулирование со стороны государства. В связи с этим, законодательные органы разных стран, включая и наше государство, принимают все новые и новые нормативные правовые документы, направценные на обеспечение национальной безопасности и интересов своих стран $[1,2]$.

Многие эксперты в своих трудах рассматривают национальную безопасность сквозь перекрестную сверку истории и современности. Основной вывод из их работ состоит в том, что внешнеполитическая и внутриполитическая доктрина государства домжна реализовываться в интересах насемения страны, российских граждан [3, 4, 6].

Стоит рассмотреть протестное движение в России 2011-2013 гг. (в СМИ использовались также названия: "болотная революция") - политические выступления граждан России, которые начались после выборов в Государственную думу VI созыва 4 декабря 2011 года, и продолжились во время кампании по выборам президента России и после состоявшихся 4 марта 2012 года президентских выборов, на которых Владимир Владимирович Путин победим в первом туре.

Данные явления, произошедшие как "болотные недовоцьства", с которыми Россия столкнулась в эти годы, следует рассматривать как первые тревожные вызовы для вцасти. Возникает реальный риск действий политических сил дмя подрыва конституционных основ государственности. Игнорирование данных явлений недопустимо и разрушительно для государства.

Стоит отметить, что в данном случае на первый план в понимании безопасности выходят условия функционирования политической системы,

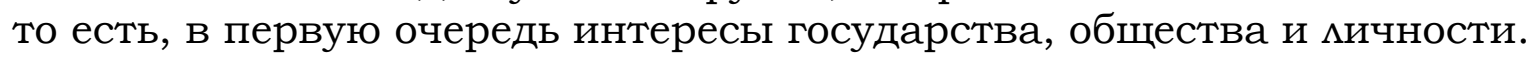

Национальная безопасность Российской Федерации надёжно обеспечивается только при повышении устойчивости страны к внешним и внутренним угрозам. Без приспособления к экономическим, политическим, военным угрозам современного мира, невозможно обеспечить безопасность государства. Эти препятствия должны быть изучены для долгосрочной стратегии обеспечения национальной безопасности Российской Федерации. 
Сам термин «безопасность» в научной митературе весьма многозначен, до сих пор не выработано четкого определения этого понятия и, что более важно отсутствует целостное представление его понимания. Попробуем проанализировать термин "безопасность", под которым в первую очередь, следует понимать именно физическое выживание и становление государства, сохранность территориальной целостности, защиту суверенитета и возможность ответить на внешние и внутренние угрозы.

Национальная безопасность становится сложной и постоянно меняющейся системой, она становится основой, на которую может ориентироваться общество, с надеждой не разрушить имеющиеся условия для жизни, при возникновении разрушительных факторов. Но и при этом иметь умения адаптироваться при изменении условий для жизни. Основа "национальной безопасности" это отношения государства, общества и мичности.

В Указе Президента РФ от 02.07.2021 г. № 400 «О стратегии национальной безопасности Российской Федерации" под национальной безопасностью понимается состояние защищенности национальных интересов Российской Федерации от внешних и внутренних угроз, при котором обеспечиваются реализация конституционных прав и свобод граждан, достойные качество и уровень их жизни, гражданский мир и согласие в стране, охрана суверенитета Российской Федерации, ее независимости и государственной целостности, социально-экономическое развитие страны [2].

На работоспособность этих факторов влияют огромное количество обстоятельств: географические, исторические, религиозные, психологические, политические, культурные, демографические, информационные, экономические, этнические и другие, связанные с национальными интересами.

Национальные интересы Российской Федерации - это интересы не только страны, но и общества, и мичности. Данные интересы имеют доцгосрочный характер, на которые ориентируется государство, общество и мичность с помощью совершенствования политики Российской Федерации, как внутренней, так и внешней.

Национальное право мюбой страны призвано защищать национальные интересы.

В данном случае акцент следует сделать не только на обеспечении усмовий развития здорового общества, на поддержание стабимьности, готовность реагировать на природные и техногенные катастрофы, преодолевать внутренние экономические и социальные кризисы, но и на преодоление внешнего дипломатического кризиса с западными странами, совершенствование сильной, надежной защиты от внешних угроз, обеспечение устойчивого развития экономики страны, борьба с терроризмом, борьба с организованной преступностью, коррупцией, налаживание отношений с международными организациями.

Исходя из вышеизложенного, можно прийти к выводу, что первый подход это внешние угрозы, адекватный ответ на них, и второй подход, при котором на первый план выходят условия функционирования общества, в первую очередь интересы государства, общества и мичности.

Вопросы мичной безопасности, национальной безопасности, международной безопасности в бомьшинстве случаев разобщены, так как связаны 
с совершенно различными юридическими сферами. Понятие "безопасность» явцяется родовым по отношению к разцичным видам безопасности, в том числе национальной, именно поэтому это требует конкретного исследования.

Необходимо анализировать происходящее в настоящее время в международном сообществе, определять наиболее вероятные и возможные угрозы национальной безопасности Российской Федерации. При этом важно исходить из наличия уже существующих в стране определенных экономических, национальных, религиозных, социально-политических проблем, которые порождают внутренние угрозы национальной безопасности. Такие проблемы как огромный разрыв между богатыми и бедными, утеря культурных ценностей, общих значимых целей общества, отсутствие возможностей дмя полноценной условий жизни, межэтническая и межконфессиональная напряженность.

Совокупность реальных и потенциальных угроз не является статичной (постоянной), угрозы могут появляться и исчезать, нарастать и уменьшаться, при этом будет изменяться и их значимость дмя безопасности. Оценка характера потенциальных и реальных угроз, вероятности их реализации в обществе воспринимается порой по-разному, и имеет существенные отличия. Как впрочем, и политическая элита России, для одних это угрожающие процессы, а дия других благоприятные. Когда ситуация становится угрожающей, угрозы могут быть реализованы с помощью военного вмешательства. Если ситуация доведена до использования военной симы, то следует отметить, что предрасположением для этого являются такие признаки как: наличие острых противоречий, наличие политической воли или решимости пойти на применение военной симы дмя разрешения накопившихся противоречий, обострение межнациональных и межэтнических отношений и другие признаки.

Государственная безопасность явцяется важнейшим видом национальной безопасности. Ее можно опредемить как состояние защищенности государственного строя, государственных органов, территориальной целостности государства, а также его суверенитета от внутренних и внешних угроз.

Состояние национальной безопасности зависит от экономических, социальных, военных, духовных факторов. Каждый из этих фракторов, имеет первостепенное значение только в опредеменный исторический момент. Возникает опасность неправильного формирования ресурсов при опредемении приоритетных направлений. Именно поэтому национальная безопасность является сложной, многоуровневой системой, рассматриваемой как общественное явмение, как теория, так и процесс.

Понятие «безопасность», в общем, имеет смысл в обеспечении и подержании состояния безопасности фундаментальных устоев общества. Где нет безопасности, там отсутствуют все необходимые возможности дмя развития государства. Тоцько в обществе, где созданы условия дмя каждой мичности, есть возможность всесторонней реализации прав и свобод граждан. В современных реалиях безопасность главная цель и неотъемлемое слагаемое деятельности граждан, общества и государства. Это важная характеристика, которая показывает уровень сопротивцяемости внешним 
и внутренним угрозам, определяющую общечеловеческую ценность и значимость общественных отношений.

Когда каждый эмемент системы вносит свой вклад в развитие системы, система становится более крепкой и приобретает целостность. Таким образом, национальная безопасность - это единое явление, которое опредемяет объективно основные потребности государства, удовлетворение которых будет сохранять и развивать существование всей нации.

Современные теоретические подходы к понятию национальной безопасности имеют ряд недостатков, которая заключается в недооценке ряда методологических аспектов формирования стратегии национальной безопасности, которая заключается в отсутствии единого алгоритма, принятия стратегических решений в сфере безопасности, это отражается в официальных документах, которые не имеют точных определений, точных целей и задач, часто ограничиваясь мишь нормами-принципами и декларативными нормами.

Подводя итоги, под национальной безопасностью следует понимать основные направления деятельности государства, реализующие национальные интересы государства и общества вообще, конкретные интересы

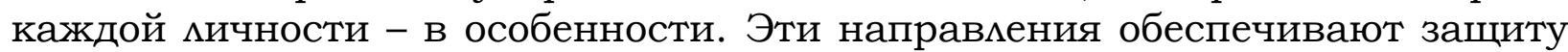
мичности, общества и государства, как от внутренних угроз, так и от угроз внешнеполитических, которые в свою очередь очень разнообразны.

Национальная безопасность, является макмусовой бумагой, которая показывает - насколько она состоятельна, способна в обществе выдерживать внешние угрозы, в состоянии приспосабливаться к меняющимся вокруг условиям, и при этом не снижать уровень качества жизни своих граждан и общества.

\section{Бибциографический список}

1. Федеральный закон от 28 декабря 2010 г. № 390-Ф3 “О безопасности» // www.consultant.ru

2. Указ Президента РФ от 02.07.2021 г. № 400 "О стратегии национальной безопасности Российской Федерации" [Эцектронный ресурс]. Режим доступа: http://publication.pravo.gov.ru/Document/View/0001202107030001

3. Герасимов А.П. Роль государства и права в обеспечении социальной безопасности. - М., 1994. - 289 с.

4. Касюк А.Я. Религиозно-политический экстремизм - угроза национальной безопасности России // Вестник МГАУ. - Общественные науки - 2017. - № 3. C. $48-57$.

5. Ирошников Д.В. Основы национальной безопасности //В кн.: Основы государства и права: учебное пособие для вузов / С. А. Комаров [и др.]; под общей редакцией С. А. Комарова. - 5-е изд., перераб. и доп. - М.: Издательство Юрайт, 2020. -678 c.

6. Спиридонова В.А. Некоторые аспекты обеспечения безопасности. - М., 2009. -238 c.

Дия цитирования: Илембетов А.К. Вызовы обеспечению национальной безопасности Российской Федерации: статья // Юридическая мысль. - 2021.- № 3 (123). - С. 28-32.

DOI: $10.47905 /$ MATGIP.202 1.123.3.007 


\title{
Challenges to ensuring the national security of the Russian Federation
}

Azamat K. Ilembetov*

\begin{abstract}
Annotation. This article discusses issues affecting legal regulation in the field of ensuring the national security of the Russian Federation. An outline of such concepts as the subject, object, tasks and goals in ensuring the national security of the Russian Federation is given, the idea is substantiated that the national security of the Russian Federation is reliably ensured only with an increase in the country's resistance to external and internal threats, which without adaptation to economic, political, military threats of the modern world, it is impossible to ensure the security of the state.
\end{abstract}

Key words: national security, state security, threats to national security, national interests.

The modern world, in comparison with the historical world, is developing at a rapid pace. Economic, technological and social processes play an important role in this. An average citizen of any country intellectually does not keep up with the development of modern technologies, since humanity does not stand still and is rapidly moving forward, new and new challenges arise in different areas of our life, including in the field of national security. The relevance of this topic is also associated with the latest global problems, for example, the COVID-19 coronavirus pandemic.

We must agree with D.V. Iroshnikov that "by nature, every living organism needs to ensure its safety. According to A. Maslow's pyramid of needs, safety comes second after physiological needs (food, water, sleep). The need for security at one time was the reason for the unification of people into states and grew into its main goal, which was mentioned in their treatises by the great Western European thinkers of the Enlightenment (J. Locke, T. Hobbes, J.-J. Rousseau, Sh.-L. Montesquieu). And today, ensuring national security is one of the main functions of every state. It must ensure both its own - state security, and the security of society and individuals. Before considering the category "national security", it is necessary to define the term "security". Under security it is customary to understand the state of security of an object, which guarantees its sustainable development"[5, p. 643].

One of the internal threats to the national security of the Russian Federation can be attributed to the demographic threat due to the low birth rate and high mortality rate of the population, its extinction, the high rate of divorce, alcoholism, drug addiction, the spread of dangerous diseases of various kinds, such as HIV, hepatitis, and at the moment and COVID19. In addition, corruption and terrorism, which are especially pronounced in some Islamic republics, etc., should also be considered a threat to national security.

* Membetov Azamat Kamilovich, Master's student of the Department of Theory of State and Law, Institute of Law, Bashkir State University. E-mail:azamatilembetov@gmail.com

Scientific adviser - Komarov Sergey Aleksandrovich, Professor of the Department of Theory of State and Law of the Institute of Law of the Bashkir State University, Doctor of Law, Professor. E-mail: SVKomarov2008@yandex.ru 
All these serious problems in the aggregate directly or indirectly affect the general well-being of the entire country and even humanity, which in turn implies legal regulation by the state. In this regard, the legislative bodies of different countries, including our state, are adopting more and more new normative legal documents aimed at ensuring national security and the interests of their countries $[1,2]$.

Many experts in their writings view national security through a crosschecking of history and modernity. The main conclusion from their work is that the foreign and domestic political doctrine of the state should be implemented in the interests of the population of the country, Russian citizens $[3,4,6]$.

It is worth considering the protest movement in Russia in 2011-2013 (the media also used the names: "swamp revolution") - political speeches of Russian citizens that began after the elections to the State Duma of the VI convocation on December 4, 2011, and continued during the campaign for the presidential elections in Russia and after the presidential elections held on March 4, 2012, which Vladimir Vladimirovich Putin won in the first round.

These phenomena, which occurred as "swamp discontent" that Russia faced in these years, should be considered as the first alarming challenges for the authorities. There is a real risk of actions of political forces to undermine the constitutional foundations of statehood. Ignoring these phenomena is unacceptable and destructive for the state.

It should be noted that in this case the conditions for the functioning of the political system come to the fore in the understanding of security, that is, primarily the interests of the state, society and the individual.

The national security of the Russian Federation is reliably ensured only by increasing the country's resistance to external and internal threats. Without adapting to the economic, political and military threats of the modern world, it is impossible to ensure the security of the state. These obstacles must be studied for a long-term strategy for ensuring the national security of the Russian Federation.

The term "safety" itself in the scientific literature is very ambiguous, there is still no clear definition of this concept and, more importantly, there is no integral understanding of its understanding. Let's try to analyze the term "security", which, first of all, should be understood as the physical survival and formation of the state, the preservation of territorial integrity, the protection of sovereignty and the ability to respond to external and internal threats.

National security is becoming a complex and constantly changing system, it becomes the basis on which society can orient itself, with the hope of not destroying the existing conditions for life, in the event of destructive factors. But at the same time, have the ability to adapt to changing living conditions. The basis of "national security" is the relationship between the state, society and the individual.

In the Decree of the President of the Russian Federation of 02.07.2021 No. 400 "On the strategy of the national security of the Russian Federation" national security is understood as the state of protection of the national interests of the Russian Federation from external and internal threats, which ensures the implementation of constitutional rights and freedoms of citizens, a decent quality and level their lives, civil peace and harmony in the country, the protec- 
tion of the sovereignty of the Russian Federation, its independence and state integrity, the socio-economic development of the country [2].

The performance of these factors is influenced by a huge number of circumstances: geographic, historical, religious, psychological, political, cultural, demographic, informational, economic and ethnic and others related to national interests.

The national interests of the Russian Federation are not only the interests of the country, but also of society and individuals. These interests are of a long-term nature, on which the state, society and the individual are guided by improving the policy of the Russian Federation, both internal and external.

The national law of any country is designed to protect national interests.

In this case, the emphasis should be placed not only on ensuring conditions for the development of a healthy society, on maintaining stability, readiness to respond to natural and man-made disasters, to overcome internal economic and social crises, but also on overcoming the external diplomatic crisis with Western countries, improving strong, reliable protection from external threats, ensuring sustainable development of the country's economy, combating terrorism, fighting organized crime, corruption, establishing relations with international organizations.

Based on the foregoing, we can come to the conclusion that the first approach is external threats, an adequate response to them, and the second approach, in which the conditions for the functioning of society, primarily the interests of the state, society and the individual, come to the fore.

The issues of personal security, national security and international security are in most cases fragmented, as they are associated with completely different legal spheres. The concept of "security" is generic in relation to various types of security, including national, that is why it requires a specific study.

It is necessary to analyze what is currently happening in the international community, to determine the most probable and possible threats to the national security of the Russian Federation. At the same time, it is important to proceed from the presence of certain economic, national, religious, socio-political problems already existing in the country, which give rise to internal threats to national security. Such problems as the huge gap between the rich and the poor, the loss of cultural values, common significant goals of society, the lack of opportunities for full-fledged living conditions, interethnic and interfaith tensions.

The aggregate of real and potential threats is not static (constant), threats can appear and disappear, increase and decrease, while their significance for security will change. Assessment of the nature of potential and real threats, the likelihood of their implementation in society is sometimes perceived differently, and has significant differences. As well as the political elite of Russia, for some these are threatening processes, while for others they are favorable. When the situation becomes threatening, the threats can be realized through military intervention. If the situation is brought to the use of military force, then it should be noted that the predisposition for this are such signs as: the presence of sharp contradictions, the presence of political will or determination to use military force to resolve the accumulated contradictions, aggravation of interethnic and interethnic relations and other signs. 
State security is the most important type of national security. It can be defined as the state of protection of the state system, state bodies, the territorial integrity of the state, as well as its sovereignty from internal and external threats.

The state of national security depends on economic, social, military, and spiritual factors. Each of these factors is of paramount importance only at a certain historical moment. There is a danger of incorrect formation of resources when determining priority areas. That is why national security is a complex, multi-level system, considered as a social phenomenon, both a theory and a process.

The concept of "security", in general, makes sense in ensuring and maintaining the state of security of the fundamental foundations of society. Where there is no security, all the necessary opportunities for the development of the state are lacking. Only in a society where conditions have been created for each individual is it possible to fully realize the rights and freedoms of citizens. In modern realities, security is the main goal and an integral component of the activities of citizens, society and the state. This is an important characteristic that shows the level of resistance to external and internal threats, which determines the universal human value and significance of social relations.

When each element of the system contributes to the development of the system, the system becomes stronger and acquires integrity. Thus, national security is a single phenomenon that objectively determines the basic needs of the state, the satisfaction of which will preserve and develop the existence of the entire nation.

Modern theoretical approaches to the concept of national security have a number of shortcomings, which lies in the underestimation of a number of methodological aspects of the formation of a national security strategy, which consists in the absence of a single algorithm, making strategic decisions in the field of security, this is reflected in official documents that do not have precise definitions, precise goals and objectives, often limiting themselves only to norms-principles and declarative norms.

Summing up, national security should be understood as the main directions of the state's activity, realizing the national interests of the state and society in general, and the specific interests of each individual in particular. These areas provide protection of the individual, society and the state from both internal threats and foreign policy threats, which in turn are very diverse.

National security is a litmus test that shows how wealthy it is, is able to withstand external threats in society, is able to adapt to changing conditions around, and at the same time not reduce the quality of life of its citizens and society.

\section{Bibliographic list}

1. Federal Law of December 28, 2010 No. 390-FZ "On Security" //www. consultant.ru

2. Decree of the President of the Russian Federation of 02.07.2021, No. 400 "On the National Security Strategy of the Russian Federation" [Electronic resource]. Access mode: http://publication.pravo.gov.ru/Document/View/0001202 107030001 
3. Gerasimov A.P. The role of the state and law in ensuring social security. Moscow, 1994. 289 p.

4. Kasiuk A.Ya. Religious and political extremism - a threat to the national security of Russia // Vestnik MGLU. Social Sciences.2017. No. 3. P. 48-57.

5. Iroshnikov D.V. Fundamentals of National Security // In the book: Fundamentals of State and Law: a textbook for universities / S. A. Komarov [and others]; edited by S. A. Komarov. 5th ed., Rev. and add. Moscow: Yurayt Publishing House, 2020. $678 \mathrm{p}$.

6. Spiridonova V.A. Some aspects of security. Moscow, 2009.238 p.

For citation: Ilembetov A.K. Challenges to ensuring the national security of the Russian Federation: article // Legal thought. 2021. No. 3 (123). P. 33-37.

DOI: $10.47905 /$ MATGIP.2021.123.3.007

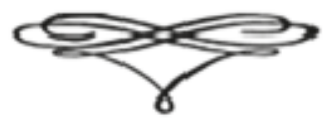




\title{
Крнтнка Г.В.Ф. Гегелем фниософско-правового учення И. Канта О своводе
}

\begin{abstract}
đ.d. Макснмов ${ }^{*}$
Аннотация. И. Кант формирует новую парадигму философии права, основанную на идее свободы. Место системообразующего элемента философии права, которое в рамках парадигмы естественного права занимал концепт естественного закона, у И.Канта занимает высший нравственный закон. Однако эта идея не помучает у него содержательной экспликации, а значит и идея свободы остается абстракцией. Г.Гегель стремится преодолеть абстрактность И.Канта в учении о свободе за счет принципа историзма, который он постепенно развивает в своих ранних произведениях.
\end{abstract}

Ключевые слова: Кант, Гегель, свобода, право, историзм, философия права, идея свободы.

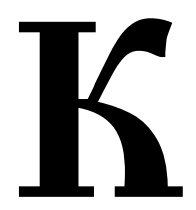

середине XVIII столетия стало очевидным, что эмпирический метод, положенный Т.Гоббсом и Дж. Аокком в основу теории общественного договора, не в состоянии раскрыть самой сущности права и определить тенденции его развития на новом витке общественного прогресса. В свою очередь, рационалистическая методология новоевропейской редакции теории естественного права не могла дать никакой альтернативы эмпиризму, кроме рассудочного дедуцирования общих положений политико-правовой науки из "врожденных идей разума", которые к середине XVIII в. представцялись чем-то произвольным и совершенно архаичным.

Новая социальная реальность, заявившая о себе в практике Великой французской революции, в идеях гуманизма, просвещения, республиканизма и прав человека, в идеях, положенных в основу эпохальных правовых документов (американской Декларации прав человека 1776 г. и французской Декларации прав человека и гражданина 1789 г.), требовала своего осмысления на принципиально новой теоретической и методологической базе. Ее основой стало трансцендентальное истолкование сущности свободы как основы права, осуществленное Кантом и переосмысленное Гегелем в соответствии с принципами системности и историзма [7, с. 21-22].

* Максимов Александр Александрович, аспирант кафедры теории и истории государства и права Юридического института (Санкт-Петербург). E-mail: sanchomaa@gmail.com. Hayчный руководитель - Комаров Сергей Александрович, профессор кафедры теории и истории государства и права Юридического института (Санкт-Петербург), доктор юридических наук, профессор. E-mail: SVKomarov2008@yandex.ru

Научный консультант - Масленников Дмитрий Владимирович, проректор Юридического института (Санкт-Петербург), доктор философских наук, професcop. E-mail: lawinstspb@mail.ru 
В результате немецкая классическая философия в своем историческом развитии формирует новую парадигму правовой мысли, не сводимую ни к традиционной теории естественного права к редакций, ни к эмпирической модеми общественного договора: "Классическая немецкая философия права ни восстанавцивает теорию естественного права, ни пролонгирует концептуальные основания общественного договора, а развивает понимание права, основанное на впервые представленной в истории науки развернутой фимософской интерпретацией христианской идеи свобод" [6, с. 43-47].

Эта парадигма в своем первоначальном варианте, предможенном Иммануилом Кантом, была основана на понимании свободы как трансцендентной данности. По Канту, свобода не может быть дана в форме созерцания, a, значит, не может быть объектом опыта. Поскольку для Канта опыт как синтетическая деятельность способности созерцания и способности суждения является единственной формой познания, постольку выведение свободы за пределы опыта означает для него ее непознаваемость. В теоретическом плане

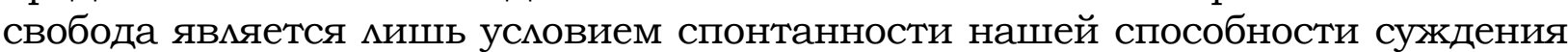
и мы знаем о ней только как об этой способности, как о факте сознания, но не имеем никакого материала дмя суждения о содержании свободы и никаких оснований для того, чтобы мыслить саму возможность такого суждения.

Основной трансцендентальной методологии, посредством которой мы приобретаем возможность высказывать суждения о свободе, для Канта явмяется аналитическое расчценение всего нашего априорного знания на начала чистого рассудочного знания [4, с. 78]. Однако условием этого анализа, по Канту, домжен быть трансцендентальный синтез. "Априорным синтезом понятия, - писал Гегель, - Кант приобрел более высокий принцип, в котором могла быть познана двойственность в единстве, стало быть, то, что требуется для истины" [1, с. 545]. Однако рассудок, по Канту, не способен понять внутренней связи суждений, их координации и т.д.

Решить эту задачу автор "Критики чистого разума" предоставцяет той способности познания, которую он называет разумом. Объект разума чисто умозрительные идеи, дмя которых в чувствах не может быть дан никакой адекватный предмет. Таким образом, идеи явцяются чисто трансцендентальными, т.е. выходящими за пределы всякого эмпирического познания. Вместе с тем Кант стремится сохранить и здесь формы опыта, поскольку познание иначе, чем как опыт, он не может помыслить.

Поскольку в сфере разума для чувств нет никакого адекватного объекта, разум сам дает своему знанию идей форму опыта. Но эта форма неизбежно оказывается трансцендентальной им^юзией. Эта им^юзия неизбежна, поскольку мышление, по Канту, вне чувственности невозможно. Но вместе с тем она все равно остается не более чем им^юзией. Ведь познанию здесь не может соответствовать никакой чувственный предмет и оно само дия себя модемирует познание, подобно чувственному опыту. Оно - всего мишь "как если бы" знание, если вспомнить известную кантовскую формумировку als ob (как если бы).

Подобная двойственность познания на уровне разума приводит к тому, что оно творит неизбежные фантомы познания, так называемые 
трансцендентальные им^юзии. Так, мы не можем не представлять себе душу как вещь, хотя рассудок учит нас, что она не является вещью. Аналогично обстоит демо и с важным дмя теории права понятием свободы. «Причинность по законам природы есть не единственная причинность, из которой можно вывести все явления в мире. Дия объяснения явлений необходимо еще допустить причинность через свободу", - утверждал Кант [4, с. 327]. Но свобода является для Канта чистой трансцендентальной идеей, а значит она не представима в формах чувственности. Следовательно, для рассудка ее бытие столь же возможно, как и небытие, а значит, дмя Канта абсолютно равноправен с приведенным выше и антитезис: "Нет никакой свободы. Все совершается в мире по законам природы" [4, с. 327].

В практическом же отношении, напротив, деятельность мичности состоит именно в реализации и объективации своей свободы. Мы не можем о ней судить, но можем видеть свободу в формах ее объективной реализации. Такими формами внешней объективности, в которых мичность может реализовать свою свободу, не разрушая при этом себя столкновением с миром необходимости, дия Канта в конечном итоге оказываются сферы гражданского общества и государства, регулируемые нормами морали и права.

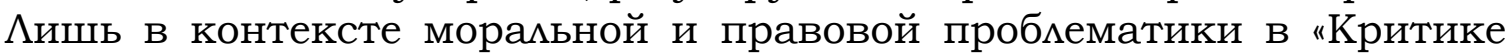
практического разума" Кант считает возможным рассуждать о содержании свободы: "Так как чистая форма закона может быть представлена только разумом, стало быть, не есть предмет чувств и, следовательно, не относится к числу явлений, то представление о ней как определяющем основании воми отмичается от всех определяющих оснований событий в природе по закону причинности, так как в этом случае определяющие основания сами должны быть явцениями. Но если никакое другое определяющее основание воли не может служить для нее законом, кроме всеобщей законодательной формы, то такую волю надо мыслить совершенно независимой от естественного закона явлений в их взаимоотношении, а именно от закона причинности. Такая независимость называется свободой в самом строгом, т.е. трансцендентальном, смысле" [5, с. 211].

Согласно "Критике практического разума", чемовек является субъектом свободы мишь в том случае, если он руководствуется разумом. Разум в силу всеобщности своей фрормы дает человеку ориентир практического действия, который позволяет ему воспроизвести себя как субъекта свободного действия. Таким рациональным ориентиром, по Канту, является категорический императив: "Категорический императив, который вообще выражает мишь то, 'что есть обязательность, гласит: поступай согласно максиме, которая в то же время может иметь силу всеобщего закона! - Следовательно, свои поступки ты должен сначала рассмотреть, исходя из субъективного основоположения; но значимо $и$ также объективно это основопоможение - это ты можешь узнать мишь потому, что, так как твой разум испытывает его: можешь $\Lambda$ ты благодаря ему мыслить себя в то же время устанавцивающим всеобщие законы, это основоположение может оказаться пригодным в качестве такого всеобщего законодательства" [5, с. 280].

Таким образом, получается, что в рамках новой парадигмы этикоправовой мысли место естественного закона занимает категорический им- 
ператив. Естественный закон был исключительно теоретическим основопоможением как в эмпирической, так и в рационалистической модели права. Речь шиа мишь о том, что явцяется основанием постулирования этого поможения: врожденные идеи, открывающиеся "естественному свету разума", или социальная конвенция. То есть свой категорический императив Кант, по сути, ставит на место естественного закона, который составцял центральную категорию и рационалистической, и эмпирической парадигм правовой науки.

Однако здесь имеется существенная разница. Категорический императив и стоящий за ним высший нравственный закон не трактуются автором “Критики практического разума" ни в качестве "врожденной идеи" разума, ни в качестве результата общественного договора. Он выступает мишь как условие практической деятельности человека, канализируемой в формах моральности или мегальности, и порождающей, соответственно, нравственность и право. Согласно Канту, именно способ отношения разума к категорическому императиву задает фрорму для норм моральности и мегальности, определяющих, соответственно, сферы морали и права: первая имеет место там, где мотивы действия чемовека принимаются как значимые, вторая - в скучае мишь формального соблюдения требований разума подчиниться высшему нравственному закону [5, с. $270-271$ ].

Гегель в своем учении о морали, нравственности, праве и государстве исходит из этой кантовской предпосылки рационального самоопределения человека относительно понятия свободы как практического принципа. Его, однако, принципиально не устраивает отказ Канта от анализа содержания понятия свободы. И в этом Гегель опирается на предпосылки трансцендентального истолкования понятия свободы, заложенные И.Г. Фихте.

Бессодержательность принципа мегальности, вытекающая из кантовского отказа от экспликации внутреннего содержания свободы, имеет следствием бессодержательность самого права. Изначально обуславливающее такой результат отношение Канта к опыту как к единственному источнику знания Гегель также отвергает, считая его чем-то вроде атавизма эмпирического способа мышления. Соответственно, «Гегель не разделял дуализм бытия и долженствования, если объявить нравственность всеобщим долженствованием, то в этом случае она теряет свой абсолютный характер... Если же рассматривать нравственность как чистое единство абстрактного закона (Кант), то нельзя, убеждал Гегель, создать систему нравственности..." [8, с. 152-153].

Если суммировать в одном слове все претензии Гегеля к политикоправовому учению Канта, то их можно бымо бы обозначить концептом "субъективизма". И. Кант, стремясь преодолеть кризис гуманитарного знания, в первую очередь права и этики, отказался от объективной модели общества, предможенной эмпиризмом Нового времени, и от субъективным установок, введенных в науку Декартом и развитых Аейбницем и Вольфом. Ни объект сам по себе и ни сам по себе субъект не могут быть источником достоверных знаний о природе, обществе и мичности. Понять процессы, протекающие в этих сферах, можно мишь в том случае, если в качестве исходного пункта познания мы примем также процесс. А именно: процесс диалекти- 
ческого взаимодействия субъекта и объект. Иначе, как предпочитал говорить Гегель, принять в качестве исходного теоретико-методологического начала науки единый "субъект-объект".

В своих классических работах Гегель разрабатывал соответствующую методоцогию новой трактовки понятия права, преодолевающей ограниченность как метафизики Нового времени, так и новейшего кантовского трансцендентализма. На основе этой методологии он осуществцяет экстраполяцию понятия свободы на проблемы отношения мичности, общества и государства, а также на проблемы особенно актуальной для сегодняшнего дня проблемы аксиологического измерения права в системе ценностей Аичности.

Речь идет прежде всего о работах зрелого Гегеля: о “Феноменологии духа", "Науке могики", "Энциклопедии философских наук". Но общетеоретический фундамент такого подхода и одновременно первые опыты соответствующей трактовки политико-правовых явлений и процессов (Аичности, общества, государства. права, закона и т.д.) активно разрабатывается уже в ранний период творчества немецкого ученого, вплоть до публикации "Феноменологии духа" в 1807 году.

Здесь, прежде всего, нужно указать на рукописи, озаглавленные "Конституции Германии", "Система нравственности", "Йенская реальная фимософия". В них постепенно намечается путь Гегеля к принципу историзма в трактовке философско-правовых категорий, которого не знала фимософия права Канта. Благодаря историческому подходу Гегелю удается истолковать понятие свободы не только в качестве субстанции, но и в качестве субъекта, основные этапы развития которого совпадают с этапами развития государственности. В итоге государство вполне могично предстает в его зрелом труде "Фицософия права" как "разумная жизнь самосознающей свободы, система нравственного мира" [2, с. 299].

Именно такое понимание сущности государства и права представляется единственно актуальным с точки зрения современной фрилософскоправовой науки.

\section{Бибциографический список}

1. Наука могики: Ч. 1. Объективная могика. Ч. 2. Субъективная могика : [Перевод] / Г. В. Ф. Гегель; [Вступ. ст. Е. С. Аинькова]. - СПб.: Наука: С.-Петерб. изд. фирма, 1997. - 799 с.

2. Гегель Г.В.Ф. Философия права. - М.: Мысль, 1990. - 524 с.

3. Гусев О.В., Масленников Д.В., Ревнова М.Б. Церковь и духовный смысл права // Юридическая мысль. - 2017. - № 1. - С. 8-14.

4. Кант И. Критика чистого разума. - М.: Мысль, 1994. - 591 с.

5. Основы метафизики нравственности; Критика практического разума; Метафизика нравов: [Перевод] / Иммануил Кант; [Вступ. ст. Я. А. С иинина, с. 552]. - СПб.: Наука: Санкт-Петербург. изд. фирма, 1995. - 528 с.

6. Масленников Д.В. Право как форма различения добра и зма // Юридическая мысль. - 2015. - № 6. - С. 42-47.

7. Масленников Д.В., Ревнова М.Б. Отношение религии и государства в фимософии права Г.В.Ф. Гегеля // Юридическая мысль. - 2018. - № 1. - С. 20-25. 
8. Фролова Е.А. Проблемы теории и философии права. - М.: Юрлитинформ, 2015. -303 c.

Дмя цитирования: Максимов А.А. Критика Г.В.Ф. Гегемем фимософско-правового учения И. Канта о свободе: статья // Юридическая мысмь. 2021. № 3 (123). С. 38-42.

DOI: $10.47905 /$ MATGIP.2021.123.3.006

\title{
Criticism G.V. F. Hegel of the philosophical-legal teaching of I. Kant about freedom
}

\begin{abstract}
Alexander A. Maximov*
Annotaton. I. Kant creates a new paradigm of the philosophy of law, which is based on the idea of freedom. The place of the main element of the philosophy of law, which in the framework of the paradigm of natural law was occupied by the concept of natural law, in I.Kant is occupied by the highest moral law. However, this idea does not receive the meaningful development of explication from him, which means that the idea of freedom remains an abstraction. G.Hegel seeks to overcome Kant's abstractness in the doctrine of freedom at the expense of the principle of historicism, which he gradually develops in his early works.
\end{abstract} freedom.

Keywords: I.Kant, G.Hegel, freedom, law, historicism, philosophy of law, idea of

By the middle of the 18th century, it became obvious that the empirical method, put by T. Hobbes and J. Locke as the basis of the theory of social contract, is not able to reveal the very essence of law and determine the tendencies of its development at a new round of social progress. In turn, the rationalistic methodology of the new European edition of the theory of natural law could not provide any alternative to empiricism, except for the rational deduction of the general provisions of political and legal science from the "innate ideas of reason", which by the middle of the XVIII century seemed to be something arbitrary and completely archaic.

A new social reality, which declared itself in the practice of the Great French Revolution, in the ideas of humanism, enlightenment, republicanism and human rights, in the ideas underlying the epoch-making legal documents (the American Declaration of Human Rights of 1776 and the French Declaration of the Rights of Man and Citizen of 1789), demanded its interpretation on a fundamentally new theoretical and methodological basis. It was based on the transcendental interpretation of the essence of freedom as the basis of law, implemented by Kant and reinterpreted by Hegel in accordance with the principles of consistency and historicism [7, p. 21-22].

* Maksimov Alexander Alexandrovich, post-graduate student of the Department of Theory and History of State and Law of the Law Institute (St. Petersburg). E-mail: sanchomaa@gmail.com. Scientific adviser - Komarov Sergey Aleksandrovich, professor of the Department of Theory and History of State and Law of the Law Institute (St. Petersburg), Doctor of Law, Professor. E-mail: SVKomarov2008@yandex.ru

Scientific consultant - Maslennikov Dmitry Vladimirovich, Vice-Rector of the Law Institute (St. Petersburg), Doctor of Philosophy, Professor. E-mail: lawinst-spb@mail.ru 
As a result, German classical philosophy in its historical development forms a new paradigm of legal thought, which is not reducible either to the traditional theory of natural law to any of its possible editions, or to an empirical model of a social contract: "Classical German philosophy of law neither restores the theory of natural law, nor prolongs the conceptual foundations of a social contract, but develops an understanding of law based on the expanded philosophical interpretation of the Christian idea of freedoms presented for the first time in the history of science" [6, p. 43-47].

This paradigm, in its original version, proposed by Immanuel Kant, was based on the understanding of freedom as a transcendental given. According to Kant, freedom cannot be given in the form of contemplation, and, therefore, cannot be an object of experience. Since for Kant experience as a synthetic activity of the ability to contemplate and the ability to judge is the only form of cognition, to the extent that the removal of freedom beyond the limits of experience means for him its unknowability. In theoretical terms, freedom is only a condition for the spontaneity of our ability to judge and we know about it only as this ability, as a fact of consciousness, but we have no material for judging the content of freedom and no reason to think about the very possibility of such a judgment.

The main transcendental methodology, through which we acquire the ability to express judgments about freedom, for Kant is the analytical division of all our a priori knowledge into the beginnings of pure rational knowledge [4, p. 78]. However, the condition for this analysis, according to Kant, must be a transcendental synthesis. "By the a priori synthesis of the concept", Hegel wrote, "Kant acquired a higher principle in which duality in unity could be cognized, therefore, what is required for truth" [1, p. 545]. However, the mind, according to Kant, is not able to understand the internal connection of judgments, their coordination, etc.

To solve this problem, the author of the Critique of Pure Reason provides that ability of cognition, which he calls reason. The object of reason is purely speculative ideas, for which no adequate object can be given in the senses. Thus, ideas are purely transcendental, i.e. going beyond the limits of any empirical knowledge. At the same time, Kant seeks to preserve the forms of experience here as well, since he cannot think otherwise than as experience.

Since there is no adequate object for the senses in the sphere of the mind, the mind itself gives its knowledge of ideas a form of experience. But this form inevitably turns out to be a transcendental illusion. This illusion is inevitable, since thinking, according to Kant, is impossible outside of sensibility. But at the same time, it still remains nothing more than an illusion. After all, cognition here cannot correspond to any sensible object, and it models cognition for itself, like sensory experience. It is just "as if" knowledge, if we recall the wellknown Kantian formulation als ob (as if).

This duality of knowledge at the level of reason leads to the fact that it creates inevitable phantoms of knowledge, the so-called transcendental illusions. Thus, we cannot but imagine the soul as a thing, although the mind teaches us that it is not a thing. The situation is similar with the concept of freedom, which is important for the theory of law. "According to the laws of na- 
ture, causality is not the only causality from which all phenomena in the world can be derived. To explain the phenomena, it is also necessary to admit causality through freedom", Kant argued [4, p. 327]. But freedom is for Kant a pure transcendental idea, which means that it cannot be represented in the forms of sensuality. Consequently, for the mind, its being is as possible as non-being, which means that for Kant the antithesis is absolutely equal with the above: "There is no freedom. Everything is done in the world according to the laws of nature" [4, p. 327].

In practical terms, on the contrary, the activity of the individual consists precisely in the realization and objectification of his freedom. We cannot judge it, but we can see freedom in the forms of its objective realization. For Kant, such forms of external objectivity, in which a person can realize his freedom without destroying himself by collision with the world of necessity, ultimately turn out to be the spheres of civil society and the state, regulated by the norms of morality and law.

Only in the context of moral and legal issues in the Critique of Practical Reason, Kant considers it possible to talk about the content of freedom: "Since the pure form of the law can only be represented by reason, therefore, it is not an object of feelings and, therefore, does not belong to the number of phenomena, then the idea of it as the determining basis of the will differs from all the determining grounds of events in nature according to the law of causality, since in this case the determining grounds themselves must be phenomena. But if no other determining basis of the will can serve as a law for it, except for the universal legislative form, then such a will must be thought of as completely independent of the natural law of phenomena in their relationship, namely of the law of causality. Such independence is called freedom in the strictest, i.e. transcendental sense" [5, p. 211].

According to the Critique of Practical Reason, a person is the subject of freedom only if he is guided by reason. Reason, by virtue of the universality of its form, gives a person a guideline for practical action, which allows him to reproduce himself as a subject of free action. Such a rational guideline, according to Kant, is the categorical imperative: "The categorical imperative, which generally expresses only what is obligatory, says: act according to a maxim, which at the same time can have the force of a universal law! - Therefore, you must first consider your actions on the basis of a subjective basis; but whether this principle is also objectively significant - you can find out only because, since your mind tests it: can you, thanks to it, think of yourself at the same time establishing universal laws, this basic principle may turn out to be suitable as such a universal legislation" [5, p. 280].

So, it turns out that within the framework of the new paradigm of ethical and legal thought, the place of natural law is taken by a categorical imperative. Natural law was an exclusively theoretical foundation in both empirical and rationalistic models of law. It was only about what is the basis for postulating this position: innate ideas that open to the "natural light of reason", or social convention. That is, Kant, in fact, puts his categorical imperative in place of natural law, which constituted the central category of both rationalistic and empirical paradigms of legal science. 
However, there is a significant difference here. The categorical imperative and the supreme moral law behind it are not interpreted by the author of the Critique of Practical Reason either as an "innate idea" of reason, or as a result of a social contract. It acts only as a condition for the practical activity of a person, canalized in the forms of morality or legality, and generates, respectively, morality and law. According to Kant, it is the way the mind relates to the categorical imperative that sets the form for the norms of morality and legality, which determine, respectively, the spheres of morality and law: the first takes place where the motives of a person's action are taken as significant, the second - in the case of only formal compliance with the requirements of reason to obey the highest moral law [5, p. 270-271].

Hegel in his doctrine of morality, ethics, law and the state proceeds from this Kantian premise of the rational self-determination of man in relation to the concept of freedom as a practical principle. However, he is fundamentally not satisfied with Kant's refusal to analyze the content of the concept of freedom. And in this Hegel relies on the premises of the transcendental interpretation of the concept of freedom, laid down by I.G. Fichte.

The empty content of the principle of legality, which follows from Kant's refusal to explicate the inner content of freedom, results in the empty content of law itself. Initially, Kant's attitude to experience as to the only source of knowledge, which caused such a result, Hegel also rejects, considering it to be something like an atavism of the empirical way of thinking. Accordingly, "Hegel did not share the dualism of being and ought, if morality is declared a universal obligation, then in this case it loses its absolute character ... If we consider morality as a pure unity of an abstract law (Kant), then it is impossible, Hegel argued, to create a system of morality ..." [8, p. 152-153].

If we summarize in one word all of Hegel's claims to the political-legal doctrine of Kant, then they could be designated by the concept of "subjectivism". I. Kant, striving to overcome the crisis of humanitarian knowledge, primarily law and ethics, abandoned the objective model of society proposed by the empiricism of the modern era, and the subjective attitudes introduced into science by Descartes and developed by Leibniz and Wolff. Neither the object itself nor the subject itself can be a source of reliable knowledge about nature, society and personality. It is possible to understand the processes taking place in these spheres only if we also take the process as the starting point of cognition. Namely: the process of dialectical interaction between the subject and the object. Otherwise, as Hegel preferred to say, accept a single "subject-object" as the initial theoretical and methodological beginning of science.

In his classical works, Hegel developed an appropriate methodology for a new interpretation of the concept of law, overcoming the limitations of both the metaphysics of modern times and the latest Kantian transcendentalism. On the basis of this methodology, he extrapolates the concept of freedom to the problems of the relationship between the individual, society and the state, as well as to the problems of the axiological measurement of law in the system of personal values that is especially urgent for today.

This is primarily about the works of the mature Hegel: the "Phenomenology of Spirit", "Science of Logic", "Encyclopedia of Philosophical Sciences". But 
the general theoretical foundation of such an approach and, at the same time, the first experiments of the corresponding interpretation of political and legal phenomena and processes (personality, society, state, law, law, etc.) were actively developed already in the early period of the German scientist's work, right up to the publication of the "Phenomenology of Spirit" in 1807.

Here, first of all, it is necessary to point to the manuscripts entitled "The Constitution of Germany", "The System of Morality", "Jena's Real Philosophy". They gradually outline Hegel's path to the principle of historicism in the interpretation of philosophical and legal categories, which Kant's philosophy of law did not know. Thanks to the historical approach, Hegel manages to interpret the concept of freedom not only as a substance, but also as a subject, the main stages of development of which coincide with the stages of development of statehood. As a result, the state quite logically appears in his mature work "Philosophy of Law" as "a reasonable life of self-conscious freedom, a system of the moral world" [2, p. 299].

It is this understanding of the essence of state and law that seems to be the only relevant one from the point of view of modern philosophical and legal science.

\section{Bibliographic list}

1. Science of logic: Part 1. Objective logic. Part 2. Subjective logic: [Translation] / GVF Hegel; [Intro. Art. E. S. Linkova]. Sankt-Petersburg: Science: St. Petersburg. ed. firm, 1997. $799 \mathrm{p}$.

2. Hegel G.V.F. Philosophy of Law. Moscow: Mysl, 1990. 524 p.

3. Gusev O.V., Maslennikov D.V., Revnova M.B. Church and the spiritual meaning of law // Legal thought. 2017. No. 1. P. 8-14.

4. Kant I. Critique of pure reason. Moscow: Mysl, 1994. 591 p.

5. Foundations of the metaphysics of morality; Criticism of practical reason; Metaphysics of Morals: [Translation] / Immanuel Kant; [Intro. Art. Ya.A. Slinina, p. 552]. Sankt-Petersburg: Science: St. Petersburg. ed. firm, 1995. 528 p.

6. Maslennikov D.V. Law as a form of distinguishing between good and evil // Legal thought. 2015. No. 6. P. 42-47.

7. Maslennikov D.V., Revnova M.B. The relationship between religion and the state in the philosophy of law of G.V.F. Hegel // Legal thought. 2018. No. 1. P. 20-25.

8. Frolova E.A. Problems of theory and philosophy of law. Moscow: Jurlitinform, 2015. 303 p.

For citation: Maksimov A.A. Criticism of G.V.F. Hegel of I. Kant's philosophical and legal doctrine of freedom: article // Legal thought. 2021. No. 3 (123). P. 43-47.

DOI: $10.47905 /$ MATGIP.2021.123.3.006

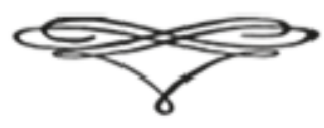




\title{
Правовое регуанрованне Госуадаственного н муннцнпального управлення фннансовымн рнскамн ПУБАНЧнО-ПравОВЫХ ОБрАзОВАнНй
}

\author{
E.đ. Макснмова*
}

\begin{abstract}
Аннотация. В данной статье рассматриваются вопросы правового регулирования государственного и муниципального управления финансовыми рисками. Цель работы состоит в уточнении важных элементов системы экономической безопасности на основе обобщения подходов к ее построению.

Автором раскрыты основные пробцемы, на которые могут быть нацелены научные исследования по вопросам дальнейшего изучения и исследования практики управления финансовыми рисками в публично-правовых образованиях, показано, что внутрисистемные риски формируются как субъектами экономической безопасности, так и ее объектами, но их отличие от внешних угроз заключается в избирательном влиянии на объекты. Сдеманы выводы, что снижение уровня финансовых рисков во многом может быть достигнуто благодаря их своевременной идентификации и политики самого государства. Отмечает, что в настоящее время накоплен значительный объем знаний, способных не только повысить эффективность бюджетной системы России, но и обеспечить ее безопасность и стабильность.

Ключевые слова: правовое регулирование, финансовые риски, публичноправовые образования, экономика, государственное управление, муниципальное управмение.
\end{abstract}

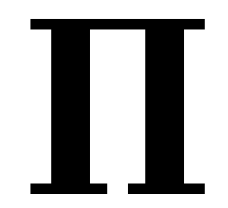

ублично-правовые образования по существу, создаются дия того, чтобы служить обществу, исполнять свой публичный долг. Защитой от чрезмерного вмешательства государства в различные сферы и зцоупотребления властными полномочиями явцяется четкое разграничение статуса публично-правового субъекта. Пубцичные образования могут рассматриваться и как субъекты административного права, и как субъекты гражданского права. Критерием отнесения отношений к той или иной группе автором предлагается использовать наличие или отсутствие свободного волеизъявления сторон.

Можно сказать, что данный вид расхода - это плата властного субъекта за пользование заемными средствами. Предоставление кредитов одного публичного образования другому демо добровольное. Взаимоотношения по поводу предоставмения кредитов и процентов по ним основаны на

\footnotetext{
* Максимова Евгения Александровна, магистрант Института права Башкирского государственного университета. E-mail: maksim0va.ea@yandex.ru.

Научный руководитель - Комаров Сергей Александрович, президент Межрегиональной ассоциации теоретиков государства и права, научный руководитель Юридического института (Санкт-Петербург), профессор кафедры теории государства и права Института права Башкирского государственного университета, доктор юридических наук, професcop. E-mail: svkomarov2008@ya.ru
} 
равенстве сторон и регулируются гражданским законодательством, о чем говорится в ст. 93.2 Бюджетного кодекса Российской Федерации [3].

Автор не анализирует группы расходов, связанные с субсидиями, поцучателями которых являются непубличные образования, предполагая, что вопрос соотношения статуса при предоставцении субсидий, как одного из видов расходов бюджета, может стать отдельной темой исследования.

Следует отметить, что отношения по поводу расходов бюджета не всегда носят административный характер. K имущественным отношениям, основанным на административном или ином властном подчинении одной стороны другой, в том числе к налоговым и другим финансовым и административным отношениям, гражданское законодательство не применяется, если иное не предусмотрено законодательством. Следовательно допускается гражданско-правовой характер регулирования отношений, в основу которых поможено властное начало, мишь в случаях, обозначенных в федеральных законах (ст. 2 ГК РФ) [2]. Поэтому необходимо строгое разграничение правового статуса публичного образования, чтобы было понимание того, к каким отношениям возможно применение норм гражданского права. Дмя разных видов правоотношений по поводу распредемения расходов бюджета характерны и разные способы судебного разрешения при возникновении споров.

Пробцема обеспечения экономической безопасности выступает объектом активных исследований преимущественно в странах с советским прошлым. Во многом этот феномен обусловцен чрезвычайно негативными социально-экономическими последствиями, вызванными рядом событий и явлений после распада единой державы на самостоятельные государства. Однако вектор и интенсивность исследований неодинаковы, как и периоды анализа. При высоких ценах на энергоносители доминировала точка зрения об отсутствии актуальности подобных исследований. Сейчас страна столкнулась с негативными воздействиями, существенно снижающими возможность социально-экономического развития. В связи с этим задача построения эффективной системы экономической безопасности приобрела особую остроту. Ее решение представляет интерес с позиции развития теории экономической безопасности, но полагаем, что наибольшее ее значение прикладное для структуры государственного управцения.

В научных публикациях проблеме определения системы экономической безопасности удемено большее внимание, чем в нормативных правовых документах. В известной работе комектива авторов под руководством B.K. Сенчагова при формулировании соответствующей дефиниции применен комплексный подход. Система экономической безопасности, по мнению авторов, состоит из семи эмементов: концепции национальной безопасности, национальных интересов России в сфере экономики, угроз экономической безопасности, индикаторов экономической безопасности, пороговых значений этих индикаторов, организационной структуры экономической безопасности, правового обеспечения экономической безопасности [20, с. 33].

Близок к комплексному подход А.А. Кайгородцева. Систему национальной экономической безопасности он представцяет в виде совокупности блоков: цель и задачи системы, национальные интересы в области экономики и экономические приоритеты, экономические угрозы (внешние и внутрен- 
ние), пороговые индикаторы экономической безопасности, правовое обеспечение экономической безопасности, организационная структура обеспечения экономической безопасности, методы обеспечения экономической безопасности [14].

Комплексный подход изможен и в работе Т.Ю. Феофицовой, но применительно к системе экономической безопасности региона, которая включает в себя взаимосвязанные компоненты: нормативные и правовые акты, регулирующие область экономической безопасности региона, субъекты управления отношениями в области экономической безопасности, объекты управления в области экономической безопасности, негативные воздействия и их последствия на состояние экономической безопасности региона, группы показатемей и индикаторов, характеризующих состояние экономической безопасности региона [21].

Мы пришли к выводу о целесообразности создания модели с учетом трех ключевых компонентов, отражающих специфику феномена экономической безопасности. К таким элементам отнесены следующие:

- риски и угрозы, без которых исследование и описание экономической безопасности теряет смысл в силу могической взаимосвязи "угрозы безопасность";

- объекты, на которые направлено негативное влияние рисков и угроз. В качестве объектов мы рассматриваем хозяйствующие субъекты вне зависимости от формы собственности и объемов деятельности. В конечном счете мюбая угроза оказывает отрицательное воздействие на широкий сектор, его отдемьный компонент или хозяйствующий субъект. Совокупный эффект от такого влияния определяет уровень экономической безопасности страны в целом и в значительной степени - региона и муниципального образования;

- субъекты системы экономической безопасности, функции и полномочия которых предусматривают противодействие негативному воздействию рисков и угроз на федеральном и региональном уровнях государственного управления и на уровне местного самоуправцения, предоставцяя средства обеспечения экономической безопасности хозяйствующих субъектов

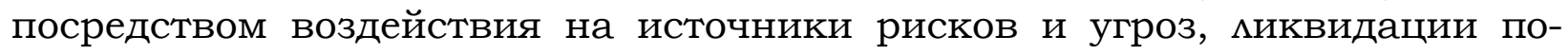
следствий, реализации мер, позволяющих компаниям усилить позиции в противостоянии подобным угрозам.

Моделируя систему экономической безопасности страны, мы исходим из того, что объективно регулирующее воздействие на субъекты экономики оказывают органы государственной власти (федерального уровня и уровня субъектов Федерации), органы местного самоуправцения, представцяющие собой субъекты управления безопасностью, которые отвечают за вопросы правового регулирования государственного и муниципального управления финансовыми рисками. Отдельно от государственных структур в качестве субъекта экономической безопасности выступает Центральный банк Российской Федерации. Однако в силу влияния субъекты управления способны создавать условия, которые формируют угрозы для экономической безопасности объектов регулирования ими сами по себе служат событиями или явлениями, содержащими рисковую составляющую. Следовательно, субъекты одновременно выступают и источником возникновения внутри- 
системных угроз. Таким образом, субъекты управления экономической безопасностью, с одной стороны, оказывают помощь объектам в обеспечении их экономической безопасности, противодействуя внутрисистемным и внешним рискам, с другой - являются их источниками [10, с. 54].

Представцяется, что внутрисистемные риски формируются как субъектами экономической безопасности, так и ее объектами, но их отличие от внешних угроз заключается в избирательном влиянии на объекты. Мы исходим из того, что в системе экономической безопасности всегда будут существовать организации, для которых конкретная угроза будет представмять разный уровень опасности даже при условии их отраслевой идентичности и одинаковых объемов деятельности.

Внешние риски и угрозы всегда действуют на систему экономической безопасности в целом. Несмотря на то, что это негативное влияние может иметь секторальную направленность, оно способно снизить степень сопротивляемости и, следовательно, уровень экономической безопасности всей системы.

Органы власти и Центральный банк Российской Федерации формируют средства обеспечения экономической безопасности, которые воздействуют на ее объекты. Кроме того, орган управления на каждом уровне располагает собственными инструментами, оказывающими регулирующее влияние на подконтрольные им организации, определяя их способность самостоятельно противодействовать внутрисистемным и внешним рискам и угрозам экономической безопасности.

Отличие представленной модели от ранее предложенных состоит в том, что субъекты экономической безопасности - органы вмасти и Центральный банк - рассматриваются одновременно и как источники возникновения рисков и угроз. В данной модели объекты безопасности сведены до микроэкономического уровня ввиду того, что совокупное состояние организаций, в конечном счете, определяет степень экономической безопасности административно-территориального образования.

Бюджет государства представляет собой основной фонд денежных средств, необходимых дмя реализации соответствующих задач. Стабильность бюджетной системы, которая предполагает бесперебойное исполнение доходной и расходной частей, а также определенный запас гарантия безопасности и суверенитета государства. Современная геополитическая обстановка требует постоянного мониторинга реальных и потенциальных угроз бюджетной системы, а уровень развития экономических и юридических знаний предоставляет обширный комплекс инструментов дмя эффективного управления государственными средствами.

В 2017 году в рамках реализации государственной программы Российской Федерации "Информационное общество" [6] была введена в действие государственная интегрированная система управления общественными финансами "Электронный бюджет" (далее программа "Электронный бюджет»), позволившая автоматизировать и объединить в единую систему различные бюджетные процедуры, а также обеспечить удаленный документооборот между участниками бюджетного процесса. Так, например, планирование государственных расходов осуществляется в соответствующей 
подсистеме программы «Электронный бюджет», которая позволяет сформировать план-график, функционально связанный с бюджетной сметой учреждения, хранить соответствующую информацию, фиксировать действия и бездействия ответственных киц. Однако, несмотря на заданный вектор развития бюджетной системы, контроль ее безопасности и стабильности не автоматизирован, а методика оценки финансовых рисков непонятна.

Финансовый контроль является важным элементом системы управления общественными финансами и подразделяется на внешний и внутренний в зависимости от субъектов, реализующих его. Бюджетные полномочия органов государственного (муниципального) финансового контроля закреплены в Бюджетном кодексе РФ, в том числе в статье 157, 160.21, 165 и др. [3]. Требование организовать систему внутреннего финансового в организации закреплено в ст.19 Федерального закона от 06.12.2011 № 402-Ф3 (ред. от 26.07.2019) "О бухгалтерском учете» [4], а также в п. 6 Приказа Минфина России от 01.12.2010 № 157н [7]. Также законодатель обязал всех администраторов доходов средств бюджета и получателей бюджетных средств, осуществляющих расходование государственных средств организовать систему внутреннего финансового контроля. Конкретные контрольные функции и порядок их осуществления зависят от уровня финансового риска. Таким образом, четкое понимание сущности категории "финансовый риск" имеет не только теоретическое, но и практическое значение.

Особенности каждого из вышеперечисленных методов уместно рассматривать при разработке единых методических рекомендаций по осуществцению финансового контроця и при формировании требований к соответствующей автоматизированной подсистеме управцения общественными финансами.

Ранее действующий порядок осуществления внутреннего фринансового контроля содержал ряд упущений, среди которых отсутствие единой системы объективных критериев дия опредемения уровня риска по каждой бюджетной процедуры. Порядок описан в приказах Министерства финансов РФ от 07.09.2016 № 356 "Об утверждении Методических рекомендаций по осуществлению внутреннего финансового контроля" [8] и в приказе Минфина России от 30.12.2016 № 822 «Об утверждении методических рекомендаций по осуществлению внутреннего финансового аудита". Последний приказ был отменен в апреле 2020 года [9].

До сих пор отсутствует единый системный подход и механизм управмения финансовыми рисками [12, с. 59]. Методические рекомендации, ранее действующие, носили рекомендательный характер.

Уровень финансового риска определяется с учетом вероятности наступления неблагоприятного события и возможного ущерба. При этом, цемесообразно рассчитывать показатели вероятности с учетом статистических данных внешнего контроля, и определить единые критерии дмя оценочной шкалы возможного ущерба.

По данным Счетной палаты РФ в 2019 году за последние 11 мет отмечается самый низкий уровень исполнения расходов федерального бюджета $(94,2 \%)$, что свидетельствует об отсутствии эффективного механизма внесения изменений в расходную часть и требует дополнительного контроля. 
Имеющиеся данные относительно поквартального исполнения федерального бюджета в 2019 году также свидетельствует об усилении неравномерности его исполнения. Так, в IV квартале 2019 года уровень исполнения составил 32,4\% показателя сводной росписи с изменениями 6 265,0 млрд рублей, что явцяется самым высоким показателем за последние 3 года (в 2017 году $30,7 \%$, в 2018 году 30,5\%) [18].

С учетом сводных данных контролирующих органов необходимо корректировать основные задачи системы внутреннего финансового контроля конкретного ведомства, учреждения, организации. При этом с учетом современного уровня развития государственных ресурсов это необходимо реализовать централизованно посредствам применения программы «Электронный бюджет" и предусмотреть систему оповещений, предупреждающих ненадмежащее исполнение бюджета.

Другим распространенным нарушением в бюджетной сфере является искажение бюджетной отчетности, причиной которых является некорректное отражение в бухгалтерском учете фактов хозяйственной деятельности. Данные нарушение может привести к различным последствиям, в том чисме может совершаться намерено с целью уменьшения налогооблагаемой базы кибо и приводить к ущербу государственных имущественных интересов.

Федеральная налоговая служба России демонстрирует эффективность практического применения системы налоговых рисков. По отчетным данным ведомства за 2019 год предупреждение налогоплательщиков о возможных рисках и их последствиях привело к добровольному погашению задолженности налогоплательщиками на общую сумму 130,6 млрд. рублей, а жалоб по итогам проверки стало в 2 раза меньше.

В настоящее время накоплен значительный объем знаний, способных не только повысить эффективность бюджетной системы России, но и обеспечить ее безопасность и стабильность. Очевидно, необходимо закрепить в нормативно-правовых актах единые критерии дмя оценки угроз дмя каждой категории хозяйствующих субъектов, а также предусмотреть предупреждающие мероприятия с целью их предотвращения. Современный уровень развития и внедрения электронных ресурсов в сфере общественных финансов позволяет обеспечить оценку финансового риска при минимальных затратах трудовых ресурсов и оперативно предоставцяя информацию, решая проблемы правового регулирования государственного и муниципального управления фринансовыми рисками, учитывая, что в п. "м" ст. 71 Конституции Российской Федерации стоит задача обеспечения безопасности мичности, общества и государства при применении информационных технологий, обороте цифровых данных [1; 14].

Снижение уровня финансовых рисков во многом может быть достигнуто благодаря их своевременной идентификации и политики самого государства.

\section{Бибинографический список}

1. "Конституция Российской Федерации" (принята всенародным голосованием 12.12.1993 с изменениями, одобренными в ходе общероссийского голосования 01.07.2020) [Эмектронный ресурс] // www.consultant.ru 
2. "Гражданский кодекс Российской Федерации (часть первая)" от 30.11.1994 N 51-Ф3 (ред. от 28.06.2021) // www.consultant.ru

3. "Бюджетный кодекс Российской Федерации" от 31.07.1998 N 145-Ф3 (ред. от 22.12.2020) (с изм. и доп., вступ. в силу с 01.01.2021) // www.consultant.ru.

4. Федеральный закон от 06.12.2011 № 402-ФЗ (ред. от 26.07.2019) “О бухгалтерском учете" // www.consultant.ru.

5. Постановление Правительства РФ от 30 декабря 2017 г. № 1701 "О соглашениях, которые предусматривают меры по социально-экономическому развитию и оздоровлению государственных финансов субъектов Российской Федерации" [Эмектронный ресурс] // www.consultant.ru.

6. Постановление Правительства РФ от 15.04.2014 № 313 (ред. от 31.03.2021) "Об утверждении государственной программы Российской Федерации "Информационное общество" / / www.consultant.ru.

7. Приказ Минфина России от 01.12.2010 № 157н (ред. от 14.09.2020) "Об утверждении Единого плана счетов бухгалтерского учета дия органов государственной власти (государственных органов), органов местного самоуправления, органов управления государственными внебюджетными фондами, государственных академий наук, государственных (муниципальных) учреждений и Инструкции по его применению" // www.consultant.ru

8. Приказ Минфина России от 07.09.2016 № 356 (ред. от 30.11.2018) “Об утверждении Методических рекомендаций по осуществлению внутреннего фринансового контроля" // www.consultant.ru.

9. Приказ Минфина России от 30.12.2016 № 822 «Об утверждении методических рекомендаций по осуществцению внутреннего финансового аудита" // www.consultant.ru

10. Гришковеи А.А. Проблемы соотношения норм административного и трудового права при регулировании отношений в сфере государственной службы / А.А. Гришковец / / Государство и право. - 2017. - № 12. - С. 11-24.

11. Ершова Е.А. Трудовое право в России / Е.А. Ершова. - М.: Статут, 2017. $620 \mathrm{c}$.

12. Ильин А.В. Расходы бюджета в конституционном государстве: дис. д-ра юрид. наук / А.В. ИАьин. - СПб., 2016. - 358 с.

13. Кадырова О.В., Растов М.A. Помитика управцения рисками организации // Омские научные чтения - 2018: Материалы Второй Всероссийской научной конференции. Омск: Изд-во ОГУ им. Ф.М. Достоевского, 2018. С. 925-927.

14. Кайгородиев А.А. Некоторые аспекты обеспечения финансовой безопасности России // Теоретическая экономика. 2019. №1 (49).

15. Комментарий к Конституции Российской Федерации / С. А. Комаров [и др.]; под ред. С.А. Комарова. - 3-е изд., перераб. и доп. - М.: Издательство Юрайт, 2019. - 333 с.

16. Аебедева О.И. Бюджетный риск: методические основы оценки и управмения. На примере краевого бюджета Хабаровского края: дисс. ... канд. экон. наук. Хабаровск, 2018.

17. Маршалл А. Принципы экономической науки: в 3-х т.: пер. с англ. М.: Прогресс, 2016. Том 1, 2. С. 238.

18. Маршам , А. Принципы экономической науки [Текст]. Т. 3. [перевод с английского] / А. Маршамл; [авт. вступ. ст.: Дж. М. Кейнс]. - М.: Прогресс; Фирма "Универс". 1993. - 350 с.

19. Маршал , А. Принципы экономической науки [Текст]. Т. 2 [перевод с английского] / А. Маршалц; [авт. вступ. ст.: Дж. М. Кейнс]. - М.: Прогресс; Фирма "Универс". 1993. - 309 с. 
20. Маршамл, А. Принципы экономической науки [Текст]. Т. 1 [перевод с английского] / А. МаршалА; [авт. вступ. ст.: Дж. М. Кейнс]. - М.: Прогресс; Фирма "Универс". 1993. - 414 с.

21. Набиуллина 1 .А. Бюджетные риски: понятие и актуальность // Молодой ученый. 2016. № 10 (57). C. 366-369 // URL: https://moluch.ru/archive/57/7816/ (дата обращения: 01.03.2021)

22. Чиканова А.А. Применение трудового законодательства к служебным отношениям на государственной гражданской службе: теория и практика: Автореф. дис. д-ра юрид. наук / $\Lambda$.А. Чиканова. - М., 2016. - 45 с.

23. Экономическая безопасность России: общий курс: учебник / под ред. В.К. Сенчагова. - М., 2005. - 895 с.

24. Феофилова Т.Ю. Модель управления экономической безопасностью региона / / Вестник евразийской науки. - 2014. - № 6 (25).

Дия цитирования: Максимова Е.А. Правовое регулирование государственного и муниципального управления финансовыми рисками публично-правовых образований: статья // Юридическая мысль. 2021. № 3 (123). С. 48-55.

DOI: 10.47905 /MATGIP.2021.123.3.002

\title{
Legal regulation of state and municipal governance of financial risks of public legal formations
}

\author{
Evgeniya A. Maksimova*
}

\begin{abstract}
Annotation. This article examines the issues of legal regulation of state and municipal financial risk management. The aim of the work is to clarify the important elements of the economic security system based on the generalization of approaches to its construction.

The author reveals the main problems that can be targeted by scientific research on the further study and research of the practice of financial risk management in public law formations, it is shown that intrasystem risks are formed both by the subjects of economic security and its objects, but their difference from external threats consists in selectively influencing objects. It is concluded that the reduction in the level of financial risks can largely be achieved due to their timely identification and the policy of the state itself. Notes that at present, a significant amount of knowledge has been accumulated that can not only increase the efficiency of the budgetary system of Russia, but also ensure its security and stability.

Key words: legal regulation, financial risks, public law formations, economics, public administration, municipal administration.

Public law formations are essentially created in order to serve society, to fulfill their public duty. A clear delineation of the status of a public legal entity

* Maksimova Evgeniya Aleksandrouna, Master's student at the Institute of Law of the Bashkir State University. E-mail: maksim0va.ea@yandex.ru.

Scientific adviser - Komarov Sergey Aleksandrovich, President of the Interregional Association of Theorists of State and Law, Scientific Director of the Law Institute (St. Petersburg), Professor of the Department of Theory of State and Law of the Institute of Law of the Bashkir State University, Doctor of Law, Professor. E-mail: svkomarov2008@ya.ru
\end{abstract}


is a protection against excessive state interference in various spheres and abuse of power. Public entities can be considered both as subjects of administrative law and as subjects of civil law. The author proposes to use the presence or absence of free expression of the will of the parties as a criterion for referring relations to a particular group.

We can say that this type of expense is the payment of a powerful subject for the use of borrowed funds. The provision of loans from one public entity to another is voluntary. The relationship regarding the provision of loans and interest on them is based on the equality of the parties and is regulated by civil law, as stated in Art. 93.2 of the Budget Code of the Russian Federation [3].

The author does not analyze the groups of expenditures associated with subsidies, the recipients of which are non-public entities, suggesting that the issue of the ratio of status in the provision of subsidies, as one of the types of budget expenditures, may become a separate topic of research.

It should be noted that relations regarding budget expenditures are not always administrative in nature. Civil law does not apply to property relations based on administrative or other power subordination of one party to the other, including tax and other financial and administrative relations, unless otherwise provided by law. Consequently, the civil law nature of the regulation of relations based on the imperious principle is allowed only in cases specified in federal laws (Article 2 of the Civil Code of the Russian Federation) [2]. Therefore, it is necessary to strictly delineate the legal status of public education, so that there is an understanding of the relations to which the norms of civil law can be applied. Different types of legal relations regarding the distribution of budget expenditures are also characterized by different methods of judicial resolution in the event of disputes.

The problem of ensuring economic security is the object of active research mainly in countries with a Soviet past. This phenomenon is largely due to the extremely negative socio-economic consequences caused by a number of events and phenomena after the disintegration of a single power into independent states. However, the vector and intensity of research are not the same, as are the periods of analysis. With high energy prices, the prevailing point of view was the lack of relevance of such studies. Now the country is faced with negative impacts that significantly reduce the possibility of socio-economic development. In this regard, the task of building an effective system of economic security has become particularly acute. Its solution is of interest from the standpoint of the development of the theory of economic security, but we believe that its greatest significance is applied to the structure of public administration.

In scientific publications, more attention is paid to the problem of determining the system of economic security than in regulatory legal documents. In the well-known work of a group of authors under the leadership of V.K. Senchagov, an integrated approach was applied when formulating the corresponding definition. The system of economic security, according to the authors, consists of seven elements: the concept of national security, national interests of Russia in the economic sphere, threats to economic security, indicators of economic security, threshold values of these indicators, the organizational structure of economic security, legal support of economic security [20, p. 33]. 
Close to the integrated approach of A.A. Kaigorodtseva. It represents the system of national economic security in the form of a set of blocks: the goal and objectives of the system, national interests in the field of economy and economic priorities, economic threats (external and internal), threshold indicators of economic security, legal support of economic security, organizational structure of ensuring economic security, methods of ensuring economic security [14].

An integrated approach is also described in the work of T.Yu. Feofilova, but in relation to the system of economic security of the region, which includes interrelated components: normative and legal acts regulating the area of economic security of the region, subjects of management of relations in the field of economic security, objects of management in the field of economic security, negative impacts and their consequences on the state economic security of the region, a group of indicators and indicators characterizing the state of economic security of the region [21].

We came to the conclusion that it is advisable to create a model taking into account three key components that reflect the specifics of the phenomenon of economic security. These elements include the following:

- risks and threats, without which the study and description of economic security loses its meaning due to the logical relationship "threat - security";

- objects to which the negative impact of risks and threats is directed. As objects, we consider economic entities, regardless of the form of ownership and volume of activity. Ultimately, any threat has a negative impact on a wide sector, its individual component or economic entity. The cumulative effect of such influence determines the level of economic security of the country as a whole and, to a large extent, of the region and the municipality;

- subjects of the economic security system, the functions and powers of which provide for counteracting the negative impact of risks and threats at the federal and regional levels of government and at the level of local government, providing means of ensuring the economic security of economic entities by influencing the sources of risks and threats, eliminating consequences, implementing measures allowing companies to strengthen their position against such threats.

Modeling the system of economic security of the country, we proceed from the assumption that the objectively regulating influence on the subjects of the economy is exerted by the state authorities (federal level and the level of the constituent entities of the Federation), local self-government bodies, which are subjects of security management, which are responsible for the issues of legal regulation of state and municipal financial risk management. Apart from state structures, the Central Bank of the Russian Federation acts as a subject of economic security. However, due to the influence, the subjects of management are able to create conditions that form threats to the economic security of regulated objects or themselves serve as events or phenomena containing a risk component. Consequently, the subjects simultaneously act as a source of the emergence of intra-system threats. Thus, the subjects of economic security management, on the one hand, assist objects in ensuring their economic security, counteracting intrasystem and external risks, on the other hand, they are their sources [10, p. 54]. 
It seems that intrasystem risks are formed both by the subjects of economic security and by its objects, but their difference from external threats lies in the selective influence on the objects. We proceed from the assumption that in the system of economic security there will always be organizations for which a specific threat will pose a different level of danger, even if their industry identity and the same volume of activity.

External risks and threats always affect the economic security system as a whole. Despite the fact that this negative impact may have a sectoral focus, it can reduce the degree of resistance and, consequently, the level of economic security of the entire system.

The authorities and the Central Bank of the Russian Federation form the means of ensuring economic security that affect its facilities. In addition, the governing body at each level has its own instruments that exert a regulatory influence on the organizations under their control, determining their ability to independently counteract internal and external risks and threats to economic security.

The difference between the presented model and those previously proposed is that the subjects of economic security - the authorities and the Central Bank - are considered simultaneously as sources of risks and threats. In this model, security objects are reduced to the microeconomic level due to the fact that the aggregate state of organizations ultimately determines the degree of economic security of an administrative-territorial entity.

The state budget is the main fund of funds necessary for the implementation of the relevant tasks. The stability of the budgetary system, which presupposes the uninterrupted execution of the revenue and expenditure parts, as well as a certain margin guarantee the security and sovereignty of the state. The modern geopolitical situation requires constant monitoring of real and potential threats to the budget system, and the level of development of economic and legal knowledge provides a wide range of tools for effective management of public funds.

In 2017, as part of the implementation of the state program of the Russian Federation "Information Society" [6], the state integrated public finance management system "Electronic Budget" (hereinafter the "Electronic Budget" program) was introduced, which made it possible to automate and combine various budget procedures into a single system, as well as to provide remote document flow between the participants in the budget process. So, for example, planning of public expenditures is carried out in the corresponding subsystem of the "Electronic Budget" program, which allows you to form a schedule, functionally related to the budget estimates of the institution, store relevant information, record the actions and inaction of responsible persons. However, despite the given vector of development of the budgetary system, the control of its security and stability is not automated, and the methodology for assessing financial risks is not clear.

Financial control is an important element of the public finance management system and is subdivided into external and internal, depending on the entities implementing it. The budgetary powers of state (municipal) financial control bodies are enshrined in the Budget Code of the Russian Federation, including in Articles 157, 160.21, 165, etc. [3]. The requirement to organize 
a system of internal financial in the organization is enshrined in Article 19 of the Federal Law dated 06.12.2011 No. 402-FZ (as amended on 26.07.2019) "On accounting" [4], as well as in clause 6 of the Order of the Ministry of Finance of Russia dated 01.12.2010 No. 157n [7]. Also, the legislator obliged all administrators of budget funds revenues and recipients of budget funds who spend public funds to organize a system of internal financial control. Specific control functions and the procedure for their implementation depend on the level of financial risk. Thus, a clear understanding of the essence of the category "financial risk" has not only theoretical but also practical significance.

It is appropriate to consider the features of each of the above methods when developing uniform guidelines for financial control and when formulating requirements for the corresponding automated subsystem of public finance management.

The earlier existing procedure for the implementation of internal financial control contained a number of omissions, including the lack of a unified system of objective criteria for determining the level of risk for each budget procedure. The procedure is described in the orders of the Ministry of Finance of the Russian Federation dated 07.09.2016 No. 356 "On approval of Methodological recommendations for the implementation of internal financial control" [8] and in the order of the Ministry of Finance of Russia dated 30.12.2016 No. 822 "On approval of methodological recommendations for the implementation of internal financial audit". The last order was canceled in April 2020 [9].

Until now, there is no unified systematic approach and financial risk management mechanism [12, p. 59]. The methodological recommendations previously in force were of a recommendatory nature.

The level of financial risk is determined taking into account the likelihood of an adverse event and possible damage. At the same time, it is advisable to calculate the probability indicators, taking into account the statistical data of external control, and to define uniform criteria for the assessment scale of possible damage.

According to the data of the Accounts Chamber of the Russian Federation, in 2019 over the past 11 years, the lowest level of execution of federal budget expenditures $(94.2 \%)$ is noted, which indicates the absence of an effective mechanism for making changes to the expenditure side and requires additional control. The available data on the quarterly execution of the federal budget in 2019 also indicates an increase in the unevenness of its execution. So, in the IV quarter of 2019 , the level of execution amounted to $32.4 \%$ of the indicator of the consolidated list with changes of $6,265.0$ billion rubles, which is the highest indicator for the last 3 years (in 2017, 30.7\%, in 2018, $30.5 \%$ ) [18].

Taking into account the summary data of the regulatory authorities, it is necessary to adjust the main tasks of the internal financial control system of a particular department, institution, organization. At the same time, taking into account the current level of development of state resources, this must be implemented centrally through the use of the "Electronic Budget" program and provide for a notification system to prevent improper budget execution.

Another widespread violation in the budgetary sphere is the distortion of budgetary reporting, the cause of which is the incorrect reflection in the ac- 
counting of the facts of economic activity. This violation can lead to various consequences, including it can be committed intentionally in order to reduce the taxable base or and lead to damage to state property interests.

The Federal Tax Service of Russia demonstrates the effectiveness of the practical application of the tax risk system. According to the department's reporting data for 2019, a warning to taxpayers about possible risks and their consequences led to the voluntary repayment of arrears by taxpayers in the total amount of 130.6 billion rubles, and complaints following the results of the audit became 2 times less.

At present, a significant amount of knowledge has been accumulated that can not only increase the efficiency of the budgetary system of Russia, but also ensure its security and stability. Obviously, it is necessary to consolidate in the regulatory legal acts uniform criteria for assessing threats for each category of economic entities, as well as to provide for preventive measures in order to prevent them. The current level of development and implementation of electronic resources in the field of public finance makes it possible to provide an assessment of financial risk with minimal labor costs and promptly provide information, solving problems of legal regulation of state and municipal financial risk management, taking into account that in paragraph "m" of Art. 71 of the Constitution of the Russian Federation is the task of ensuring the safety of the individual, society and the state when using information technologies, the circulation of digital data [1; p. 14].

Reducing the level of financial risks can largely be achieved due to their timely identification and the policy of the state itself.

\section{Bibliographic list}

1. "The Constitution of the Russian Federation" (adopted by popular vote on 12.12.1993 with amendments approved during the all-Russian vote on 01.07.2020) [Electronic resource] // www.consultant.ru

2. "Civil Code of the Russian Federation (part one)" dated 30.11.1994 No. 51-FZ (as amended on 28.06.2021) // www.consultant.ru

3. "Budget Code of the Russian Federation" dated July 31, 1998 No. 145-FZ (as amended on December 22, 2020) (as amended and supplemented, entered into force on 01.01.2021) // www.consultant.ru.

4. Federal Law dated 06.12.2011 No. 402-FZ (as amended on 26.07.2019) "On accounting" / / www.consultant.ru.

5. Decree of the Government of the Russian Federation of December 30, 2017 No. 1701 "On agreements that provide for measures for the socio-economic development and improvement of public finances of the constituent entities of the Russian Federation" [Electronic resource] // www.consultant.ru.

6. Decree of the Government of the Russian Federation of 15.04.2014 No. 313 (revised from 31.03.2021) "On approval of the state program of the Russian Federation" Information Society" // www.consultant.ru.

7. Order of the Ministry of Finance of Russia dated 01.12.2010 No. 157n (as revised from 14.09.2020) "On approval of the Unified Chart of Accounting Accounts for State Authorities (State Bodies), Local Self-Government Bodies, Management Bodies of State Extra-budgetary Funds, State Academies of Sciences, state (municipal) institutions and Instructions for its application "// www.consultant.ru 
8. Order of the Ministry of Finance of Russia dated 07.09.2016 No. 356 (as amended on 30.11.2018) "On the approval of Methodological recommendations for the implementation of internal finance control "/ / www.consultant.ru.

9. Order of the Ministry of Finance of Russia dated 30.12.2016 No. 822 "On approval of methodological recommendations for the implementation of internal financial audit" / / www.consultant.ru

10. Grishkovets A.A. Problems of the ratio of the norms of administrative and labor law in the regulation of relations in the sphere of public service. Grishkovets // State and Law. 2017. No. 12. P. 11-24. 620 p.

11. Ershova E.A. Labor law in Russia / E.A. Ershova. Moscow: Statut, 2017.

12. Ilyin A.V. Budget expenditures in a constitutional state: dis. dr. jurid. Sciences / A.V. Ilyin. Sankt-Petersburg, 2016. 358 p.

13. Kadyrova O.V., Rastov M.A. Organization risk management policy // Omsk Scientific Readings - 2018: Proceedings of the Second All-Russian Scientific Conference. Omsk: Publishing house of OSU im. F.M. Dostoevsky, 2018. S. 925-927.

14. Kaigorodtsev A.A. Some aspects of ensuring the financial security of Russia // Theoretical Economics. 2019. No. 1 (49).

15. Commentary on the Constitution of the Russian Federation / S. A. Komarov [and others]; ed. S.A. Komarov. 3rd ed., Rev. and add. Moscow: Yurayt Publishing House, 2019. 333 p.

16. Lebedeva O.I. Budgetary Risk: Methodological Foundations of Assessment and Management. On the example of the regional budget of the Khabarovsk Territory: diss. ... cand. econom. sciences. Khabarovsk, 2018.

18. Marshall, A. Principles of Economic Science [Text]. T. 3. [translated from English] / A. Marshall; [ed. entry Art.: J. M. Keynes]. Moscow: Progress; Firm "Univers". 1993. $350 \mathrm{p}$.

19. Marshall, A. Principles of Economic Science [Text]. T. 2 [translated from English] / A. Marshall; [ed. entry Art.: J. M. Keynes]. Moscow: Progress; Firm "Univers". 1993. 309 p.

20. Marshall, A. Principles of Economic Science [Text]. T. 1 [translated from English] / A. Marshall; [ed. entry Art.: J. M. Keynes]. Moscow: Progress; Firm "Univers". 1993. 414 p.

21. Nabiullina L.A. Budgetary Risks: Concept and Relevance // Young Scientist. 2016. No. 10 (57). P. 366-369 // URL: https://moluch.ru/archive/57/7816/ (date of access: 01.03.2021)

22. Chikanova L.A. Application of labor legislation to service relations in the public civil service: theory and practice: Author's abstract. dis. Dr. jurid. sciences / L.A. Chikanov. Moscow, 2016. 45 p.

23. Economic security of Russia: general course: textbook / ed. V.C. Senchagova. Moscow, 2005. 895 p.

24. Feofilova T.Yu. Model of economic security management of the region // Bulletin of Eurasian Science. 2014. No. 6 (25).

For citation: Maksimova E.A. Legal regulation of state and municipal management of financial risks of public legal entities: article // Legal thought. 2021. No. 3 (123). P. 55-61.

DOI: $10.47905 /$ MATGIP.2021.123.3.002

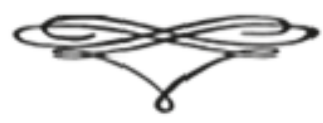




\title{
5.1.4. УГОАОВНО-ПРАВОВЫЕ НАУКИ \\ (12.00.08 - УГОАОвное право и крнмннологня; УГОАОвнО-НСПОАнНТЕАЬНОЕ ПрАВО)
}

\author{
Удк 340 \\ ББК 67.0 \\ DOI: 10.47905/MATGIP.2021.123.3.008 \\ Конфнскацня нмущества \\ каK угОАОвное наказанне
}

M.Ф. Гареєв ${ }^{*}$

\begin{abstract}
Аннотация. В статье рассматривается и обосновывается необходимость возобновления в уголовном праве института конфискации имущества в качестве уголовного наказания. Необходимость его возобновления обусловлена наличием ряда преступных деяний, представляющих угрозу обществу, государству, национальной безопасности Российской Федерации. В настоящее время законодательная регламентация конфискации имущества в качестве иной меры уголовноправового характера, вызванная неопределенностью его сущности, целевых установок и механизма назначения, не выполняет предупредительную задачу, установленную уголовным законодательством.
\end{abstract}

Кмючевые слова: уголовное законодательство, национальная безопасности, конфискация имущества, иные меры уголовно-правового характера, угомовное наказание, меры уголовно-правового воздействия, предупреждение преступцений.

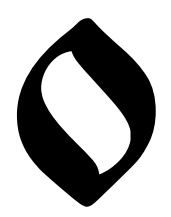

дним из противоречивых институтов уголовного права является конфискация имущества. С момента принятия в 1996 г. УК РФ рассматриваемый институт регламентировался как уголовное наказание. Однако Федеральным законом от 08 декабря 2003 г. № 162-Ф3 конфискация имущества была полностью исключена из уголовного законодательства. Впоследствии конфискация имущества на основании Федерального закона от 27 июля 2006 г. № 153-ФЗ бы$\Lambda$ восстановлена в качестве иной меры уголовно-правового характера.

Возобновление конфискации имущества в уголовном законодательстве обусловлено принятием Российской Федерации ряда международных обязательств. В частности, к ним относятся: Конвенция ООН против коррупции, принятая Резолюцией 58/4 на 51-м пленарном заседании 58-1 сессии Генеральной Ассамблеи ООН 31 октября 2003 г. (ратифицирована

* Гареев Марат Фаизович, доцент Юридического института (Санкт - Петербург), кандидат юридических наук. E-mail: gareeff.marat2013@yandex.ru 
Федеральным законом от 8 марта 2006 г. № 40-Ф3 «О ратификации Конвенции Организации Объединенных Наций против коррупции»); Конвенция ООН против транснационацьной организованной преступности. (ратифицирована Федеральным законом от 26 апреля 2004 г. № 26-Ф3) и др.

Большинство авторов рассматривают конфискацию имущества в качестве альтернативных наказанию мер уголовно-правового воздействия, как одну из форм реализации уголовной ответственности.

K такому автору относится В.В. Палий. Он указал следующее: «конфискация имущества - это иная мера уголовно-правового характера,

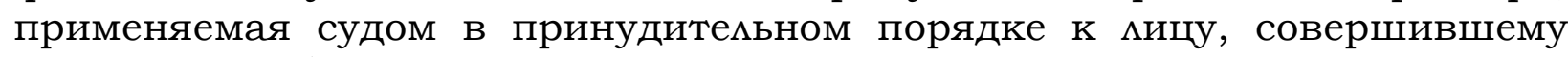
преступное общественно опасное деяние, в целях восстановцения нарушенных прав законного владемьца и предупреждения новых преступцений" [17, с. 326].

Как принудительное, окончательное, безвозмездное изъятие государством имущества с предоставлением государству права определять его судьбу, характеризует конфискацию имущества А.А. Пропостин [18, с. 131].

Данные подходы к конфискации имущества явцяются узкими, поскольку они не отражают процессуальные аспекты, указывающие об изъятии имущества на основании обвинительного приговора суда, как это имеет место в уголовном законе.

Заслуживает интерес позиция Ф.К. Набиумлина, который указал следующее: "конфискация имущества - это некарательная мера уголовноправового характера, имеющая принудительный и безвозмездный характер, заключающийся в обращении в собственность государства имущества, которое так или иначе связано с совершением преступления, принадлежащее обвиняемому мибо другому мицу, назначаемая судом наряду с наказанием" [15, с. 22].

Обращение внимание на некарательной характер конфискации имущества в действующем УК РФ указывает, что она относится к иным мерам уголовно-правового характера, выступающей альтернативной формой реамизации уголовной ответственности, а не к наказанию.

По мнению Б.В. Волженкина, «при современном законодательном урегулировании правовая природа конфискации остается загадкой" [5].

K противоречивым выводам относительно рассматриваемого института приходит Э.В. Мартыненко, дифференцируя конфискацию имущества, как наказание, и в качестве иной меры уголовно-правового характера

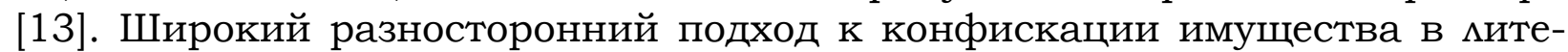
ратуре объясняется ее законодательной неопределенностью.

По данному поводу высказалась Т.В. Кленова. Она полагает: "В настоящее время конфискация имущества - это законодательно предусмотренная мера уголовно-правового воздействия с неопредеменным статусом" [11].

Законодательное определение конфискации содержится в ч. 1 ст. 1041 УК РФ. Под ним понимается принудительное безвозмездное изъятие и обращение в собственность государства на основании обвинительного приговора имущества, перечисленного в данной норме уголовного закона (пункты “а", "б", "В", "Г»). 
О сущности конфискации имущества в митературе также встречаются самые разнообразные подходы к раскрытию ее правовой природы.

Наиболее отчетливо по данному вопросу высказался Ф.Р. Сундуров, указав, что правоограничения в конфискации имущества "не имеют карательного характера, то есть они направлены, в отличие от наказания, на причинение страданий осужденному, обусловмены прежде всего интересами его исправления и предупреждения новых преступлений” [21, с. 200].

Об отсутствии карательного потенциала у конфискации имущества отметила Н.А. Аопашенко: "предусмотренная ныне в уголовном законодательстве конфискация имущества носит некарательный характер, обусловменный:

1) тем, что основная часть предмета конфискации относится к имуществу, полученному преступным путем, то есть имуществу, которое никогда не было собственностью или не находимось в законном вмадении у преступника;

2) тем, что имущество, в которое вышеназванное имущество было превращено или преобразовано, ими доходы от преступно нажитого иму-

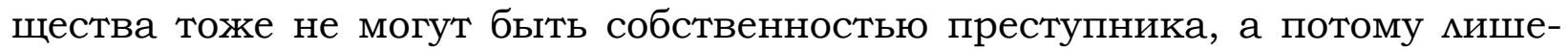

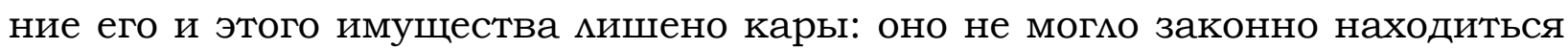
у этого мица;

3) тем, что имущество, которое использовано или предназначено преступником для финансирования терроризма или названных в законе преступлений, связанных с организованной преступностью, явцяется имуществом, прикосновенным к преступлению, а сами мица, предусматривающие такое назначение имущества, даже находившегося до той поры в собственности или законном вцадении мица, финансирующего опасную преступность, - совершают преступления, при этом тяжкие. Поэтому изъятие и этого имущества и обращение его в собственность государства не содержит элементов кары по отношению к преступнику: он сам опредемиц судьбу своего имущества, вовлекая его в преступцение. Фактически это то же орудие или средства совершения преступления, о которых говорит уголовный закон в п. "Г» ч. 1 ст. 104.1 УК РФ [12].

Заслуживает внимания позиция Т.В. Кленовой, которая раскрывает конфискацию имущества, как одну из мер уголовно-правового воздействия [11, с. 39-40].

Наряду с этим, законодательная неопредеменность конфискации имущества, отсутствие норм в уголовном законе, регламентирующих ее назначение, как это имеет место с наказанием (гл. 10 УК РФ) или с принудительными мерами медицинского характера, отнесенные законодателем также к иным мерам уголовно-правового характера (ст. ст. 100 - 104 УК РФ), а также отсутствие целевых установок, не способствуют выполнению предупредительных задач уголовного законодательства (ст. 2 УК РФ).

K одному из недостатков можно отнести неопределенность целевых установок конфискации имущества. Вполне оправданно об их сложности и дискуссионности указывает Н.А. Аопашенко [12, с. 48].

Отмечают о недостатках основания и целей применения конфискации А.И. Рарог [19, с. 56] и С.Г. Кемина [10, с. 287]. В частности, С.Г. Кеми- 
на отмечает следующее: "... Следует признать, что гл. 15.1 УК РФ не дописана, так как в ней не определены основания и цели применения этой нормы ... и большие сомнения вызывает перечень преступлений, по которым конфискация может быть применена" [10, с. 287].

Отсутствие точных и конкретных целевых установок свойственно не только конфискации имущества, но и для других альтернативных форм реализации уголовной ответственности. Как резонно отмечает В.А. Каргин: "общим недостатком всех иных мер уголовного правового характера является отсутствие нормативного опредемения их целей" [9, c. 252-253].

Отдемьные авторы рассматривают не цели конфискации имущества, а обращаются к ее функциям. Одним из таких авторов явцяется Д.Ю. Борченков. Он полагает, что существуют общие (восстановительная, специально-превентивная, общепредупредительная) и специальные (Аишение полученного в результате преступления имущества, восстановление и упорядочивание нормативной основы отношений собственности и нормальной экономической деятельности, устранение экономической основы терроризма и организованной преступности, обеспечение возмещения ущерба, причиненного преступлением, фискальная) функции [4, с. 7].

При этом Д.Ю. Борченков отрицает цели конфискации имущества, указывая, что цели устанавливаются в законе обычно тогда, "когда правоприменителю, то есть суду, предоставляется возможность по своему усмотрению (но в рамках, указанных в законе) индивидуализировать меру уголовной ответственности. Назначение же конфискации имущества, если устанавливается основание дия ее применения, носит дмя суда обязательный характер. Суд не может воздержаться от ее назначения при наличии соответствующего основания или как-то изменить объем подлежащего конфискации имущества, например, постановить о конфискации только части имущества, полученного в результате совершения преступления" $[4$, c. 17].

По сравнению с предыдущим автором, Н.А. Мопашенко раскрывает цели конфискации имущества. Она указывает, что цели рассматриваемой меры и цели уголовного наказания совпадают в том, что "и та и другая направлены на предупреждение преступлений; при этом цемью конфискации выступают как общая, так и специальная превенция" [12, с. 54].

В значительной мере, конфискация имущества должна быть направмена на восстановление социальной справедмивости. Основное предназначение конфискации имущества заключается не в том, чтобы покарать преступника, а в том, чтобы отобрать полученное преступным путем имущества, «недопущения его дальнейшего использования преступником - есть закономерный итог преступной деятельности. То есть восстановление социальной справедливости заключается здесь в приведение в первоначальное (на момент совершения преступления) состояния имущества преступника; мишение его плодов преступления, что делает бессмысленной саму преступную деятельность [12, с. 55].

Исходя из различных подходов, имеющих место в митературе, конфискация имущества, выступая в качестве одной из мер уголовно-правового 
воздействия, должна выполнять задачу предупреждения преступных деяний, как это предписывается ст. 2 УК РФ [2, с. 53].

Законодательные проблемы, характерные в настоящее время дия конфискации имущества, существенно снижают эффективность ее воздействия на ряд преступных явцений, представцяющих повышенную общественную опасность для общества и государства, и не способствуют достижению одной из основных задач уголовного законодательства, направленного на предупреждение преступлений (ст. 2 УК РФ).

В пользу данных доводов свидетельствуют ряд источников, которые буквально пестрят информацией о росте террористической [6] и коррупционной преступности [21]. Например, отмечается, что место России в рейтинге по Гцобальному индексу терроризма остается довольно высоким (в 2018 г. 34 место; на 1 место выше, чем в 2017 г.) [20].

О росте терроризма указывает судебная статистика. Так, в 2016 г. по факту совершения террористического акта (ст. 205 УК РФ) было вынесено 7 обвинительных приговоров, а в отношении других преступлений террористической направленности (ст. ст. 205.1 - 205.6, 206 УК РФ) - 116. В 2017 г. по ст. 207 УК РФ вынесено обвинительных приговоров по 13 уголовным демам, а в отношении других преступцения (ст. ст. 205.1 - 205.6, 206 УК РФ) 243. В 2018 г. по ст. 205 УК РФ вынесено обвинительных приговоры по 18 уголовным делам, а по ст. ст. 205.1 - 205.6, 206 УК РФ - 282. В 2019 г. данные показатели составили соответственно 24 и 315, а в 2020 г. 12 и 424 [7].

В свою очередь попытки законодателя расширить в уголовном законе отдемьные составы преступлений террористической направленности в виде содействующих террористической деятельности (ст. $205^{1}$ УК РФ), санкция за которое при квалифицирующем составе (ч. 4) выше, чем при совершении террористического акта (ст. 205 УК РФ), а также другие преступные деяния, предусмотренные ст. ст. $205^{2}-205^{6}$ УК РФ, не способствовали выполнению предупредительной задачи уголовного законодательства, предусмотренного ст. 2 УК РФ.

Особую озабоченность вызывает рост наркопреступности. Отдельные источники отмечают о существенном росте незаконного оборота наркотиков, который в настоящее время превышает в десятки раз [8].

Наряду с ростом наркопреступности, а по данным МВД России, в 2020 г. произошел рост на 66\%, также наметился рост экстремистских преступлений на 40\%. [14].

Проблема роста распространения наркотиков уже стала приобретать угрожающие масштабы и в состоянии негативно отразиться на национальной безопасности нашей страны, поэтому была принята Стратегия государственной антинаркотической политики Российской Федерации на период до 2030 г." (утверждена Указом Президента РФ от 23 ноября 2020 г. № 733), о чем говорится в раздеме III данного документа.

ДАя предупреждения террористической и коррупционной преступности, а также иных преступных деяний, включая незаконный оборот наркотиков, посягающих на значимые социальные ценности, следует, есми не уничтожить, поскольку достичь таких задач весьма затруднительно, 
то, по крайней мере, значительно подорвать материальную и финансовую базу подобных преступлений. Осуществить предупредительную функцию уголовного законодательства представляется возможной только посредством принудительного изъятия финансовых и материальных средств, являющихся благоприятной средой дмя вышеперечисленных преступных явлений.

Именно это обстоятельство обусловило принятие Российской Федерацией таких международных правовых актов, как Конвенция ООН против коррупции, принятая Резолюцией 58/4 на 51-м пленарном заседании 58-1 сессии Генеральной Ассамблеи ООН 31 октября 2003 г.; Конвенция ООН против транснациональной организованной преступности и др.

Низкая эффективность правоприменения рассматриваемого института обусловлена отсутствием законодательного механизма его назначения, тогда как при назначении наказания суд руководствуется гц. 10 УК РФ. Данную главу уголовного закона не представцяется возможным распространить в отношении иных мер уголовно-правового характера, к которой относится конфискация имущества. Как уже было отмечено, законодатель предусмотрел механизм назначения в отношении принудительных мер медицинского характера, закрепленных в ст. ст. 100 - 104 УК РФ.

Как показывает судебная статистика правовая неопределенность конфискации имущества обусловила ее редкое применение. К примеру, в 2016 г. конфискация имущества была применена в отношении 2499 осужденных. В 2017 г., как гласит статистика Судебного департамента при Верховном Суде РФ применена мера уголовно-правового характера в виде конфискации имущества (ст. $104^{1}$ УК РФ) в отношении 2320 осужденных. Далее, данный государственный орган в статистических данных обозначает конфискацию имущества как применение меры уголовно-процессуального характера, ссылаясь на ст. $104^{1}$ УК РФ, указав что в 2018 г. оно было применено в отношении 2755 осужденных, в 2019 г. - 3001 миц, а в 2020 г. - 2932 осужденных [7].

О редком применении судами конфискации имущества также отмечает Э.В. Мартыненко: «отсутствие законодательной регламентации правил назначения конфискации имущества как «иной меры уголовно-правового характера, по нашему мнению, явцяется одной из причин ее редкого применения судами" [13, с. 22].

Вышеизложенные проблемы законодательной регламентации конфискации имущества привели к тому, что в настоящее время в судебной практике применяется так называемая специальная конфискация имущества, которая заключается в изъятии предмета орудий, оборудования и средств совершения преступления.

Предположим, у вора-домушника изъяли "фомку", выступающую в качестве орудия преступления, или у взяточника денежные купюры. Впоследствии "фомка" подлежит конфискации и уничтожению, как вещественное доказательство, а предмет взятки обращается в доход государства.

Об этом указывают отдельные пункты, содержащиеся в разъяснениях Постановления Пиенума Верховного Суда РФ от 14 июня 2018 г. № 17 "О некоторых вопросах, связанных с применением конфискации имущества в угомовном судопроизводстве». В п. 4 данного судебного акта указано, что 
"...деньги и другие ценности, переданные в качестве взятки ими предмета коммерческого подкупа под контролем органов, осуществцяющих оперативно-розыскную деятельность, с целью задержания с поличным мица, заявившего требование о даче взятки или коммерческом подкупе, возвращаются их владельцу, если он до передачи ценностей добровоцьно сообщил о таком требовании" [1].

Согласно п. 5 данного Постановцения Пленума Верховного Суда РФ по уголовным демам о преступлениях террористической и экстремистской направленности, конфискации подмежит мюбое имущество, принадмежащее обвиняемому, явцяющееся орудием, оборудованием или иным средством совершения преступления. K такому имуществу могут относиться сотовые телефоны, персональные компьютеры, иные электронные средства связи и коммуникации, которые использовались им, в частности:

для размещения в средствах массовой информации мибо электронных или информационно-телекоммуникационных сетях текстовых, аудио-, видео- и других материалов, содержащих публичное оправдание терроризма и (или) призывы к террористической деятемьности;

для непосредственной подготовки к террористической деятельности (обучения в целях осуществления террористической деятельности; пропаганды и распространения запрещенной митературы террористической и экстремистской направценности и т.п.) [1].

Очевидно, что при таком подходе к законодатемьной регламентации конфискации и преобладании в судебной практике специальной конфискации имущества не представляется возможным достичь эффективных результатов, направленных на предупреждение преступных деяний, представляющих повышенную социальную опасность, поскольку источники финансирования подобного рода преступной деятемьности, явцяющиеся

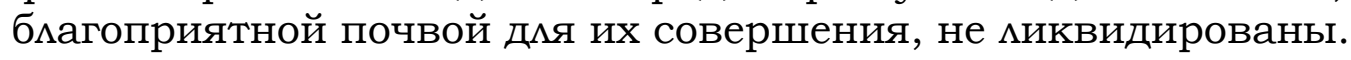

Проведенный выше анализ наглядно показывает, что правопримени-

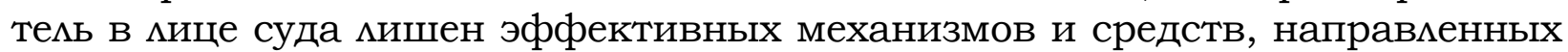
на предупреждение вышеперечисленных преступных деяний, представмяющих повышенную социальную опасность для российского общества и государства. Ранее такой механизм бым заложен в ст. 52 УК РФ, закрепившей конфискацию имущества в виде наказания, назначение которого представ ялось возможным в соответствии с гл. 10 УК РФ.

В этой связи наиболее предпочтительным является предложение председателя Следственного комитета Российской Федерации А.И. Бастрыкина, который неоднократно предлагал восстановить конфискацию имущества в качестве уголовного наказания, которая применялась до ее отмены Федеральным законом от 08 декабря 2003 г. и, соответственно, предусмотреть ее применение в отношении миц, совершивших тяжкие и особо тяжкие преступления [3].

С учетом возросшей угрозы ряда преступлений террористической и коррупционной направленности, широкого распространения незаконного оборота наркотических средств и одурманивающих веществ, а также иных преступных деяний, представляющих повышенную социальную опасность, предлагается расширить применение конфискации имущества, чем это име- 
мо место, когда она была регламентирована в уголовном законе в качестве наказания. По этому поводу заслуживает внимание предложение Ф.Р. Сундурова, который предмагает следующее: "... В интересах более решительного противодействия организованной преступности, коррупции, терроризму, ставших в России по существу национальным бедствием, следовало бы предусмотреть в УК РФ конфискацию имущества у осужденного за эти преступления и членов его семьи, совместно проживающих с ним, имущества и доходов от него, полученных в результате из совершения.

Причем конфискацию следовало бы распространить не только на имущество, которое проходит по конкретному уголовному делу, но и на имущество, законность приобретения которого не может объяснить виновный. Мы ... имеем в виду такие ситуации, когда стоимость имущества виновного и членов его семьи в десятки раз превышает их законные доходы" $[21$, c. 200$]$.

Таким образом, закрепленная в действующем УК РФ конфискация имущества в качестве иной меры уголовно-правового характера, являясь по сути вспомогательной альтернативой угоцовной ответственности, с отсутствием целевых установок, неопределенностью механизма его назначения, в настоящее время не выполняет свое социальное предназначенное, направленное на предупреждение опасных преступных деяний, представмяющих реальную опасность для общества и государства.

По этой причине предмагается возобновить конфискацию имущества в качестве дополнительного уголовного наказания в Общей части УК РФ, раскрыв его понятие, сущность и целевые установки. В связи с отнесением конфискации к наказанию, его назначение осуществлялось бы в рамках главы 10 УК РФ.

Далее, закрепить конфискацию имущества в ряде санкций Особенной части УК РФ. При этом конфискацию имущества закрепить во всех санкциях, предусматривающих ответственность за совершение преступлений террористической, экстремисткой, коррупционной направленности, преступлений в сфере незаконного сбыта наркотических средств и иных одурманивающих веществ.

Дия реализации предупредительной функции уголовного законодательства следует конфискацию имущества предусмотреть за ряд преступных деяний, совершаемых из корыстных побуждений (кража, разбой, грабеж и др.). По мнению автора, конфискацию имущества следует закрепить в санкциях за совершение убийства или причинение тяжкого вреда здоровью, совершенное из корыстных побуждений. В обязательном порядке, следует конфискацию имущества распространить на все составы мошеннических действий, поскольку данный вид преступной деятемьности стал приобретать масштабный характер [23].

Наряду с этим следует предусмотреть в уголовно-исполнительном законодательстве перечень имущества, которое не подлежит принудительному и безвозмездному изъятию, необходимое осужденному ими мицам, находящимся на его иждивении. Ранее такой перечень был закреплен в УИК РФ. К такому имуществу, например, должны быть отнесены одежда, домашняя утварь и другие предметы первой необходимости. Основным 
предназначением такого запрета должна быть защита жизненно необходимых интересов осужденного и чценов его семьи. При этом в уголовноисполнительном законе следует оговорить, что предметы роскоши, выступающие предметами повседневного пользования, подмежат конфискации. В качестве примера может служить золотой унитаз или стол из дорогой породы дерева, стоимостью более одного мимлиона рубцей.

В целом, возрождение конфискации имущества в качестве наказания будет направлена на выполнение предупредительных задач уголовного законодательства и будет способствовать обеспечению национальной безопасности нашей страны.

\section{Бибциографический список}

1. Постановление Пленума Верховного Суда РФ от 14 июня 2018 г. № 17 "О некоторых вопросах, связанных с применением конфискации имущества в уголовном судопроизводстве" / /Бюлметень Верховного Суда РФ. 2018. № 8.

2. Бавсун М.В. Уголовно-правовое воздействие: идеология, цели и средства и реализации: дисс. док... юрид. наук. - Омск, 2013. - С. 53.

3. Бастрыкин предложил вернуть в УК конфискацию имущества коррупционеров //Режим доступа: https://www.rbk.ru/society/16/07/2019/ 5d2d5d0a9a 7947da7aed9. (дата обращения - 16 августа 2021 г.)

4. Борченков Д.Ю. Конфискация имущества как мера уголовно-правового характера: понятие, природа, социальное предназначение и порядок применения: автореф. ... дис. канд. юрид. наук. - Казань, 2007. - С. 7.

5. Волженкин Б.В. Загадки конфискации //Правоведение. - 2008. - № 2. C. $4-20$.

6. Генпрокуратура назвала число террористических преступлений в 2020 году // Российская газета. 03 февраля 2021 г.; В МВД сообщили о росте на 22\% преступлений террористического характера в 2020 году - Общество - ТАСС. [Эмектронный ресурс] //Режим доступа: //https://tass.ru/obschesto/ 8948653 (дата обращения - 15 августа 2021 г.); Статистика террористической активности в России. [Эмектронный ресурс] //Режим доступа: //https://www.iminfin.ru/news/303 (дата обращения - 16 августа 2021 г.); В России выросло число террористических преступлений - Рамблер/новости. [Электронный ресурс] //Режим доступа: https / / news.rambler.ru/crime/45297046 (дата обращения - 16 августа 2021 г.).

7. Данные судебной статистики. Судебный департамент при Верховном Суде РФ. [Эмектронный ресурс] //Режим доступа: www.cdep.ru/index. php?id=79 (дата обращения - 16 августа 2021 г.).

8. Как пандемия повлияла на оборот наркотиков в России и в мире // Российская газета, 2000, 28 июня.

9. Каргин В.A. К вопросу о нормативном структурировании предписания, закрепляющих цели применения мер уголовно-правового характера. //Категория "цель" в уголовном, уголовно-исполнительном праве и криминологии /Материалы IV Российского конгресса уголовного права (28 - 29 мая 2009 г.). - М.: Проспект, 2009. - C. 252-253.

10. Келина С.Г. Иные меры уголовно-правового характера как институт уголовного права. //Уголовное право: стратегия развития в XXI веке. /Материалы IV Международной научно-практической конференции. - М.: ТK "Велби", Проспект, 2007. - С. 287.

11. Кленова Т.В. Конфискация имущества как средство уголовной политики в России //Институт конфискации имущества в законодательстве государств - 
членов Совета Европы и в российском законодательстве: материалы международного семинара /отв. ред. С.В. Землюков. - Барнаул, 2008. - С. 39-40.

12. Аопашенко Н.А. Конфискация имущества: монография. - М.: Юрлитинфоро, 2012. - C. 40-41.

13. Мартыненко Э.В. Конфискация имущества в действующем российском уголовном праве: автореф. дис. ... канд. юрид. наук. - М., 2010. - С. 133.

14. МВД зафиксировало за год рост преступлений, связанных с наркотиками, на 66\%, экстремистских - на 40\% - Афиша Daily. [Электронный ресурс] // Режим доступа: https://daili.afisha.ru/news/44186 (дата обращения - 16 августа 2021 г.).

15. Набиуллин Ф.К. Некарательное меры уголовно-правового характера: природа, система и социально-правовое назначение //Автореф. дис. ... канд. юрид. наук. - Казань, 2008. - С. 22.

16. О состоянии коррупционной преступности в 2020 году. [Электронный ресурс] //Режим доступа: https:// procrf.ru/news/print/2410410 (дата обращения 16 августа 2021 г.); Генпрокуратура сообщила о росте коррупции в России. // Новая газета. 30.03.2021 г.; В Генпрокуратуре сообщили о росте уголовных дел по фактам коррупции. Российская газета. Федеральный выпуск № 93 (8444) 28.04.2021 г.; Краснов сообщил о росте количества коррупционных преступлений с крупным ущербом в России - Общество - ТАСС. [Эмектронный ресурс] // https://ass.ru/obschestvo/941337. (дата обращения - 16 августа 2021 г.).

17. Палий В.В. Проблемы определения видов иных мер уголовно-правового характера //Уголовное право: стратегия развития в XXI веке: материалы VIII Meждународной научно-практической конференции (27-28 января 2011 г.). - М.: Проспект, 2011. - С. 326.

18. Пропостин А.А. Конфискация имущества: прошлое, настоящее, будущее: монография. - М.: Юрлитинформ, 2011. - С. 131.

19. Рарог А.И. Институт конфискации имущества нуждаются в совершенствовании //Институт конфискации имущества в законодательстве государств членов Совета Европы и в российском законодательстве: материалы Международного семинара. - Барнаум, 2008. - С. 56.

20. Статистика террористической активности в России. [Электронный ресурс] //Режим доступа: https:www.iminfin.ru/news/303. (дата обращения - 16 августа 2021 г.).

21. Сундуров Ф.Р. Конфискация имущества: национальный и международно-правовой аспекты //Научные основы уголовного права и процессы глобализации: материалы V Российского конгресса уголовного права (27 - 28 мая 2010 г.). М.: Проспект, 2010. - С. 200.

22. Уголовное право России. Общая часть: учебник /под ред. Ф.Р. Сундурова, И.А. Тарханова. - М.: Статут. 2009. - С. 701 - 702.

23. Число дел о мошенничестве рекордно выросло на фоне пандемии :: Общество :: РБК. [Эмектронный ресурс]. Режим доступа: https://rbc.ru/society/ 31/08/2020/5f48ea169a79477e21e25d9d. (дата обращения - 16 августа 2021 г.); Почему в кризис возрастает риск стать жертвой финансовых мошенников. // Российская газета. 25.03.2020 г.; Подсчитаны мимлиардные потери россиян из-за телефонных мошенников: Банки: Экономика. [Эмектронный ресурс]. //Режим доступа: http://Lenta.ru/news/2020/12/24/crime/. (дата обращения - 16 августа 2021 г.).

Дая цитирования: Гареев М.Ф. Конфискация имущества как уголовное наказание: статья // Юридическая мысль. 2021. № 3 (123). С. 62-71.

DOI: $10.47905 /$ MATGIP.2021.123.3.008 


\section{Confiscation of property as a criminal punishment}

Marat F. Gareev *

Annotation. The article discusses and substantiates the need to renew the institution of confiscation of property in criminal law as a criminal punishment. The need to resume it is due to the presence of a number of criminal acts that pose a threat to society, the state, and the national security of the Russian Federation. Currently, the legislative regulation of the confiscation of property as another measure of a criminal-legal nature, caused by the uncertainty of its essence, targets and the mechanism of appointment, does not fulfill the preventive task established by the criminal legislation.

Key words: criminal legislation, national security, confiscation of property, other measures of a criminal law nature, criminal punishment, measures of criminal law influence, crime prevention.

Confiscation of property is one of the controversial institutions of criminal law. Since the adoption in 1996 of the Criminal Code of the Russian Federation, the institution in question has been regulated as a criminal punishment. However, by Federal Law No. 162-FZ of December 8, 2003, the confiscation of property was completely excluded from the criminal legislation. Subsequently, the confiscation of property on the basis of Federal Law No. 153-FZ of July 27, 2006 was reinstated as another measure of a criminal law nature.

The resumption of the confiscation of property in the criminal law is due to the adoption of a number of international obligations by the Russian Federation. In particular, these include: The UN Convention against Corruption, adopted by Resolution 58/4 at the 51st plenary meeting of the 58-1 session of the UN General Assembly on October 31, 2003 (ratified by Federal Law No. 40-FZ of March 8, 2006 "On Ratification of the United Nations Convention against Corruption"); UN Convention against Transnational Organized Crime (ratified by the Federal Law of April 26, 2004 No. 26-FZ), etc.

Most authors consider the confiscation of property as an alternative to punishment measures of criminal law impact, as one of the forms of implementation of criminal liability.

This author includes V.V. Paliy. He pointed out the following: "confiscation of property is another measure of a criminal-legal nature, applied by a court forcibly to a person who has committed a criminal socially dangerous act, in order to restore the violated rights of the legal owner and prevent new crimes" [17, p. 326].

The confiscation of property of A.A. Propostin [18, p. 131].

These approaches to confiscation of property are narrow because they do not reflect the procedural aspects indicating the seizure of property on the basis of a conviction, as is the case in criminal law.

The position of F.K. Nabiullin, who pointed out the following: "confiscation of property is a non-punitive measure of a criminal-legal nature, which

* Gareev Marat Faizovich, associate professor of the Law Institute (St. Petersburg), candidate of legal sciences. E-mail: gareeff.marat2013@yandex.ru 
has a compulsory and gratuitous nature, which consists in turning into the property of the state property that is in one way or another connected with the commission of a crime belonging to the accused or to another person, appointed by the court along with with punishment "[15, p. 22].

Paying attention to the non-punitive nature of the confiscation of property in the current Criminal Code of the Russian Federation indicates that it refers to other measures of a criminal-legal nature, serving as an alternative form of implementation of criminal liability, and not to punishment.

According to B.V. Volzhenkina, "with the modern legislative regulation, the legal nature of confiscation remains a mystery" [5].

E.V. Martynenko comes to contradictory conclusions regarding the institution under consideration, differentiating the confiscation of property as a punishment, and as another measure of a criminal-legal nature [13]. The wide, versatile approach to confiscation of property in the literature is explained by its legislative uncertainty.

T.V. Klenova believes: "at present, confiscation of property is a legally prescribed measure of criminal law with an undefined status" [11].

The legislative definition of confiscation is contained in Part 1 of Art. 1041 of the Criminal Code of the Russian Federation. It is understood as a compulsory gratuitous seizure and turning into state ownership on the basis of a conviction of the property listed in this norm of the criminal law (paragraphs "a", "b", "c", "d").

On the essence of confiscation of property in the literature there are also a variety of approaches to the disclosure of its legal nature.

F.R. Sundurov, pointing out that legal restrictions in the confiscation of property "are not punitive in nature, that is, they are aimed, in contrast to punishment, at inflicting suffering on the convict, are primarily due to the interests of his correction and prevention of new crimes" [21, p. 200].

The lack of punitive potential in the confiscation of property was noted by N.A. Lopashenko: "the confiscation of property provided for in the criminal law is non-punitive, due to:

1) the fact that the main part of the subject of confiscation relates to property obtained by criminal means, that is, property that has never been property or was not in legal possession of the criminal;

2) the fact that the property into which the aforementioned property was turned or transformed, or the proceeds from the criminally acquired property, also cannot be the property of the criminal, and therefore deprivation of him and this property is deprived of punishment: it could not legally be with this person;

3) the fact that the property that is used or intended by the criminal to finance terrorism or crimes related to organized crime named in the law is property related to the crime, and the persons themselves providing for such a designation of property, even if it was previously owned or legal possession of a person who finances dangerous crime - commit crimes, while grave. Therefore, the seizure of this property and its turning into the property of the state does not contain elements of punishment in relation to the criminal: he himself determined the fate of his property, involving him in a crime. In fact, this is the 
same instrument or means of committing a crime, which the criminal law speaks of in paragraph "d" of Part 1 of Art. 104.1 of the Criminal Code of the Russian Federation [12].

The position of T.V. Klenova, which reveals the confiscation of property as one of the measures of criminal law [11, p. 39-40].

Along with this, the legislative uncertainty of the confiscation of property, the absence of norms in the criminal law regulating its purpose, as is the case with punishment (Chapter 10 of the Criminal Code of the Russian Federation) or with compulsory medical measures, which are also referred by the legislator to other measures of a criminal legal nature (Art. $100-104$ of the Criminal Code of the Russian Federation), as well as the lack of targets, do not contribute to the implementation of the preventive tasks of the criminal legislation (Art. 2 of the Criminal Code of the Russian Federation).

One of the drawbacks is the uncertainty of the targets for the confiscation of property. It is quite justified that N.A. Lopashenko [12, p. 48].

They note about the shortcomings of the grounds and purposes of applying the confiscation of A.I. Rarog [19, p. 56] and S.G. Kelina [10, p. 287]. In particular, S.G. Kelina notes the following: “... It should be admitted that Ch. 15.1 of the Criminal Code of the Russian Federation is not completed, since it does not define the grounds and purposes for the application of this norm ... and the list of crimes for which confiscation can be applied is in great doubt" [10, p. 287].

The lack of precise and specific targets is characteristic not only of property confiscation, but also of other alternative forms of implementation of criminal liability. As V.A. Kargin: "a common drawback of all other measures of a criminal legal nature is the lack of a normative definition of their goals" [9, p. 252-253].

Some authors do not consider the purpose of confiscation of property, but refer to its functions. One of these authors is D.Yu. Borchenkov. He believes that there are general (restorative, special-preventive, general preventive) and special (deprivation of property obtained as a result of a crime, restoration and ordering of the normative basis of property relations and normal economic activity, elimination of the economic basis of terrorism and organized crime, provision of compensation for damage caused crime, fiscal) function [4, p. 7].

At the same time D.Yu. Borchenkov denies the goals of confiscation of property, pointing out that the goals are usually established in the law when "when the law enforcement officer, that is, the court, is given the opportunity, at his own discretion (but within the framework specified in the law), to individualize the measure of criminal liability. The appointment of the confiscation of property, if the basis for its application is established, is binding on the court. The court cannot refrain from appointing it, if there is an appropriate reason, or somehow change the amount of property subject to confiscation, for example, order the confiscation of only part of the property obtained as a result of a crime" [4, p. 17].

Compared with the previous author, N.A. Lopashenko reveals the purpose of the confiscation of property. She points out that the goals of the measure under consideration and the goals of criminal punishment coincide in that 
"both are aimed at preventing crimes; in this case, the purpose of confiscation is both general and special prevention" [12, p. 54].

To a large extent, the confiscation of property should be aimed at restoring social justice. The main purpose of the confiscation of property is not to punish the criminal, but to take away the property obtained by criminal means, "preventing its further use by the criminal is a natural result of criminal activity. That is, the restoration of social justice consists here in bringing to the initial (at the time of the commission of the crime) state of the property of the criminal; depriving him of the fruits of a crime, which makes the very criminal activity senseless [12, p. 55].

Based on the various approaches in the literature, confiscation of property, acting as one of the measures of criminal law, must fulfill the task of preventing criminal acts, as prescribed by Art. 2 of the Criminal Code of the Russian Federation [2, p. 53].

Legislative problems currently characteristic of confiscation of property significantly reduce the effectiveness of its impact on a number of criminal phenomena that pose an increased public danger to society and the state, and do not contribute to the achievement of one of the main tasks of criminal legislation aimed at preventing crimes (Article 2 of the Criminal Code RF).

A number of sources testify in favor of these arguments, which are literally full of information about the growth of terrorist [6] and corruption criminality [21]. For example, it is noted that Russia's place in the ranking according to the Global Terrorism Index remains quite high (in 2018 - 34th place; 1 place higher than in 2017) [20].

The growth of terrorism is indicated by judicial statistics. So, in 2016 on the fact of committing a terrorist act (Art.205 of the Criminal Code of the Russian Federation) 7 convictions were issued, and in relation to other crimes of a terrorist nature (Art.206.1 - 205.6, 206 of the Criminal Code of the Russian Federation) - 116 under Art. 207 of the Criminal Code of the Russian Federation, convictions were passed in 13 criminal cases, and in relation to other crimes (Articles 205. 1 - 205.6, 206 of the Criminal Code of the Russian Federation) - 243. In 2018, under Art. 205 of the Criminal Code of the Russian Federation, convictions were passed in 18 criminal cases, and under Art. Art. 205.1 205.6, 206 of the Criminal Code of the Russian Federation - 282. In 2019, these indicators were 24 and 315, respectively, and in 2020 - 12 and 424 [7].

In turn, the legislator's attempts to expand in the criminal law certain elements of terrorist offenses in the form of contributing to terrorist activities (Article 2051 of the Criminal Code of the Russian Federation), the sanction for which with a qualifying composition (part 4) is higher than for committing a terrorist act (Article 205 of the Criminal Code RF), as well as other criminal acts under Art. Art. 2052-2056 of the Criminal Code of the Russian Federation, did not contribute to the implementation of the preventive task of the criminal legislation provided for in Art. 2 of the Criminal Code of the Russian Federation.

The rise in drug-related crime is of particular concern. Some sources note a significant increase in drug trafficking, which currently exceeds dozens of times [8]. 
Along with the growth of drug-related crime, and according to the Ministry of Internal Affairs of Russia, in 2020 there was an increase of $66 \%$, and there was also an increase in extremist crimes by $40 \%$ [14].

The problem of the growth in the spread of drugs has already begun to acquire alarming proportions and is in a position to negatively affect the national security of our country, therefore, the Strategy of the State Anti-Drug Policy of the Russian Federation for the period up to 2030 was adopted" (approved by the Decree of the President of the Russian Federation of November 23, 2020 No. 733), as described in section III of this document.

To prevent terrorist and corruption crimes, as well as other criminal acts, including drug trafficking, that infringe on significant social values, it is necessary, if not to destroy, since it is very difficult to achieve such tasks, then at least significantly undermine the material and financial base of such crimes. ... It seems possible to carry out the preventive function of the criminal legislation only through the compulsory seizure of financial and material resources, which are a favorable environment for the above criminal phenomena.

It was this circumstance that led to the adoption by the Russian Federation of such international legal acts as the UN Convention against Corruption, adopted by Resolution 58/4 at the 51st plenary meeting of the 58-1 session of the UN General Assembly on October 31, 2003; UN Convention against Transnational Organized Crime, etc.

The low efficiency of law enforcement of the institution in question is due to the lack of a legislative mechanism for its appointment, while when imposing a sentence, the court is guided by Ch. 10 of the Criminal Code of the Russian Federation. It is not possible to extend this chapter of the criminal law in relation to other measures of a criminal-legal nature, which include the confiscation of property. As already noted, the legislator has provided for a mechanism for the appointment of compulsory medical measures, enshrined in Art. Art. 100 104 of the Criminal Code of the Russian Federation.

Judicial statistics show that the legal uncertainty of property confiscation has led to its rare use. For example, in 2016, property confiscation was applied to 2,499 convicts. In 2017, according to the statistics of the Judicial Department at the Supreme Court of the Russian Federation, a criminal measure was applied in the form of confiscation of property (Article 1041 of the Criminal Code of the Russian Federation) against 2,320 convicts. Further, this state body in the statistical data designates the confiscation of property as the application of a measure of a criminal procedural nature, referring to Art. 1041 of the Criminal Code of the Russian Federation, indicating that in 2018 it was applied against 2,755 convicted persons, in $2019-3,001$ persons, and in 2020 - 2,932 convicted persons [7].

E.V. Martynenko also notes the rare use of property confiscation by the courts: "the absence of legislative regulation of the rules for assigning confiscation of property as "another measure of a criminal-legal nature, in our opinion, is one of the reasons for its rare application by the courts" [13, p. 22].

The aforementioned problems of legislative regulation of property confiscation have led to the fact that at present the so-called special confiscation of property is used in judicial practice, which consists in the seizure of the object of tools, equipment and means of committing a crime. 
Suppose a burglar-thief has seized a "crowbar", which acts as an instrument of crime, or banknotes from a bribe-taker. Subsequently, the "crowbar" is subject to confiscation and destruction as material evidence, and the object of the bribe is turned into state revenue.

This is indicated by certain points contained in the clarifications of the Resolution of the Plenum of the Supreme Court of the Russian Federation of June 14, 2018 No. 17 "On some issues related to the use of confiscation of property in criminal proceedings". Clause 4 of this judicial act states that “... money and other valuables transferred as a bribe or the subject of commercial bribery under the control of the bodies carrying out operational-search activities, with the aim of red-handed arrest of a person who has filed a demand for a bribe or commercial bribery, are returned to their owner if, prior to the transfer of values, he voluntarily informed about such a request" [1].

According to clause 5 of this Resolution of the Plenum of the Supreme Court of the Russian Federation on criminal cases on crimes of terrorist and extremist orientation, any property belonging to the accused, which is an instrument, equipment or other means of committing a crime, is subject to confiscation. Such property may include cell phones, personal computers, other electronic means of communication and communications that were used by him, in particular:

for posting in the media or electronic or information and telecommunication networks text, audio, video and other materials containing a public justification of terrorism and (or) calls for terrorist activity;

for direct preparation for terrorist activities (training in order to carry out terrorist activities; propaganda and dissemination of prohibited terrorist and extremist literature, etc.) [1].

Obviously, with such an approach to the legislative regulation of confiscation and the predominance of special confiscation of property in judicial practice, it is not possible to achieve effective results aimed at preventing criminal acts that pose an increased social danger, since the sources of financing for this kind of criminal activity, which are fertile ground for their commission are not eliminated.

The above analysis clearly shows that the law enforcement officer, represented by the court, is deprived of effective mechanisms and means aimed at preventing the above criminal acts, which pose an increased social danger to Russian society and the state. Previously, such a mechanism was laid down in Art. 52 of the Criminal Code of the Russian Federation, which secured the confiscation of property in the form of a punishment, the appointment of which seemed possible in accordance with $\mathrm{Ch} .10$ of the Criminal Code of the Russian Federation.

In this regard, the most preferable is the proposal of the Chairman of the Investigative Committee of the Russian Federation A.I. Bastrykin, who repeatedly proposed to restore the confiscation of property as a criminal punishment, which was applied before its abolition by the Federal Law of December 8, 2003, and, accordingly, to provide for its application in relation to persons who have committed grave and especially grave crimes [3].

Taking into account the increased threat of a number of terrorist and corruption-related crimes, the wide spread of illicit trafficking in narcotic drugs 
and intoxicating substances, as well as other criminal acts posing an increased social danger, it is proposed to expand the use of confiscation of property than was the case when it was regulated in the criminal law. as punishment. In this regard, the proposal of F.R. Sundurov, who suggests the following: “... In the interests of more decisive opposition to organized crime, corruption, terrorism, which have essentially become a national disaster in Russia, the Criminal Code of the Russian Federation should provide for the confiscation of property from the person convicted of these crimes and his family members living with him, property and income from it, received as a result of the commission.

Moreover, the confiscation should be extended not only to property that is being held in a specific criminal case, but also to property, the legality of the acquisition of which cannot be explained by the culprit. We... mean such situations when the value of the property of the guilty person and his family members is tens of times higher than their legal income" [21, p. 200].

Thus, the confiscation of property enshrined in the current Criminal Code of the Russian Federation as another measure of a criminal law nature, being in fact an auxiliary alternative to criminal liability, with the absence of targets, the uncertainty of the mechanism of its appointment, currently does not fulfill its social purpose, aimed at preventing dangerous criminal acts posing a real danger to society and the state.

For this reason, it is proposed to resume the confiscation of property as an additional criminal punishment in the General Part of the Criminal Code of the Russian Federation, revealing its concept, essence and objectives. In connection with the classification of confiscation as a punishment, his appointment would be carried out within the framework of Chapter 10 of the Criminal Code of the Russian Federation.

Further, to fix the confiscation of property in a number of sanctions of the Special Part of the Criminal Code of the Russian Federation. At the same time, the confiscation of property should be enshrined in all sanctions that provide for liability for committing terrorist, extremist, corruption-related crimes, crimes in the field of illegal sale of narcotic drugs and other intoxicating substances.

To implement the preventive function of criminal legislation, confiscation of property should be provided for a number of criminal acts committed from selfish motives (theft, robbery, robbery, etc.). According to the author, the confiscation of property should be enshrined in sanctions for the commission of murder or infliction of grievous bodily harm, committed out of selfish motives. Without fail, the confiscation of property should be extended to all types of fraudulent activities, since this type of criminal activity began to acquire a large-scale character [23].

Along with this, it is necessary to provide in the criminal executive legislation a list of property that is not subject to compulsory and gratuitous seizure, which is necessary for the convicted person or persons dependent on him. Previously, such a list was enshrined in the PEC of the Russian Federation. Such property, for example, should include clothing, household utensils and other basic necessities. The main purpose of such a prohibition should be to protect the vital interests of the convicted person and his family members. At 
the same time, it should be stipulated in the penal law that luxury goods that are everyday items are subject to confiscation. An example is a gold toilet bowl or a table made of expensive wood, which costs more than one million rubles.

In general, the revival of confiscation of property as a punishment will be aimed at fulfilling the preventive tasks of criminal legislation and will contribute to ensuring the national security of our country.

\section{Bibliographic list}

1. Resolution of the Plenum of the Supreme Court of the Russian Federation of June 14, 2018 No. 17 "On some issues related to the use of confiscation of property in criminal proceedings" // Bulletin of the Supreme Court of the Russian Federation. 2018. No. 8.

2. Bavsun M.V. Criminal law impact: ideology, goals and means and implementation: diss. doc... jurid. sciences. Omsk, 2013. P. 53.

3. Bastrykin proposed to return to the Criminal Code the confiscation of the property of corrupt officials // Access mode: https://www.rbk.ru/society/16/07/ 2019/ 5d2d5d0a9a7947da7aed9. (date of appeal - August 16, 2021)

4. Borchenkov D.Yu. Confiscation of property as a measure of a criminal-legal nature: concept, nature, social purpose and application procedure: author. ... dis. Cand. jurid. sciences. Kazan, 2007.- P. 7.

5. Volzhenkin B.V. Riddles of confiscation // Jurisprudence. 2008. No. 2. P. 4-20.

6. The Prosecutor General's Office named the number of terrorist crimes in 2020 // Rossiyskaya Gazeta. February 03, 2021; The Ministry of Internal Affairs reported a $22 \%$ increase in terrorist crimes in 2020 - Society - TASS. [Electronic resource] // Access mode: //https://tass.ru/obschesto/ 8948653 (date of access - August 15, 2021); Statistics of terrorist activity in Russia. [Electronic resource] // Access mode: //https://www.iminfin.ru/news/303 (date of access - August 16, 2021); The number of terrorist crimes has increased in Russia - Rambler / news. [Electronic resource] // Access mode: https // news.rambler.ru / crime / 45297046 (date of access August 16, 2021).

7. Judicial statistics data. Judicial Department at the Supreme Court of the Russian Federation. [Electronic resource] // Access mode: www.cdep.ru/index. php? id $=79$ (date accessed August 16, 2021).

8. How the pandemic affected drug trafficking in Russia and in the world // Rossiyskaya Gazeta, 2000, 28 June.

9. Kargin V.A. On the issue of the normative structuring of the prescription that secures the objectives of the application of measures of a criminal-legal nature. // Category "purpose" in criminal, penal law and criminology / Materials of the IV Russian Congress of Criminal Law (May 28-29, 2009). Moscow: Prospect, 2009. P. 252-253.

10. Kelina S.G. Other measures of a criminal-legal nature as an institution of criminal law. / / Criminal law: development strategy in the XXI century. / Materials of the IV International Scientific and Practical Conference. Moscow: TC "Welby", Prospect, 2007. P. 287.

11. Klenova T.V. Confiscation of property as a means of criminal policy in Russia // Institute of confiscation of property in the legislation of the member states of the Council of Europe and in Russian legislation: materials of an international seminar / otv. ed. S.V. Zemlyukov. Barnaul, 2008. P. 39-40.

12. Lopashenko N.A. Confiscation of property: monograph. Moscow: Jurlitinform, 2012. P. 40-41. 
13. Martynenko E.V. Confiscation of property in the current Russian criminal law: author. dis. ... Cand. jurid. sciences. Moscow, 2010. P. 133.

14. The Ministry of Internal Affairs recorded a $66 \%$ increase in drug-related crimes over the year, and 40\% in extremist crimes - Afisha Daily. [Electronic resource] // Access mode: https://daili.afisha.ru/news/44186 (date of access - August 16, 2021).

15. Nabiullin F.K. Non-punitive measures of a criminal-legal nature: nature, system and socio-legal purpose // Avtoref. dis. ... Cand. jurid. sciences. Kazan, 2008. P. 22.

16. On the state of corruption crime in 2020. [Electronic resource] // Access mode: https: // procrf.ru/news/print/2410410 (date of access - August 16, 2021); The Prosecutor General's Office reported on the growth of corruption in Russia. //New Newspaper. 03/30/2021; The Prosecutor General's Office reported on the growth of criminal cases on the facts of corruption. Russian newspaper. Federal issue No. 93 (8444) April 28, 2021; Krasnov reported an increase in the number of corruption crimes with large damage in Russia - Society - TASS. [Electronic resource] //https:// ass.ru/obschestvo/941337 (date of appeal - August 16, 2021).

17. Paliy V.V. Problems of determining the types of other measures of a criminal-legal nature // Criminal law: development strategy in the XXI century: materials of the VIII International scientific-practical conference (January 27-28, 2011). Moscow: Prospect, 2011. P. 326.

18. Propostin A.A. Confiscation of property: past, present, future: monograph. Moscow: Jurlitinform, 2011. P. 131.

19. Rarog A.I. The institution of property confiscation needs to be improved. // The Institute for Confiscation of Property in the Legislation of the Member States of the Council of Europe and in Russian Legislation: Proceedings of the International Seminar. Barnaul, 2008. P. 56.

20. Statistics of terrorist activity in Russia. [Electronic resource] // Access mode: https: www.iminfin.ru/news/303. (date of appeal - August 16, 2021).

21. F.R. Sundurov Confiscation of property: national and international legal aspects // Scientific foundations of criminal law and processes of globalization: materials of the V Russian Congress of Criminal Law (May 27-28, 2010). Moscow: Prospect, 2010. P. 200.

22. Criminal law of Russia. General part: textbook / ed. F.R. Sundurova, I.A. Tarkhanov. Moscow: Statute, 2009. P. 701-702.

23. The number of cases of fraud has grown at a record amid the pandemic :: Society: RBC. [Electronic resource]. Access mode: https://rbc.ru/society/ 31/08/2020 / 5f48ea169a79477e21e25d9d. (date of circulation - August 16, 2021); Why does the risk of becoming a victim of financial frauds increase during a crisis? // Russian newspaper. 03/25/2020; Calculated billions in losses of Russians due to telephone scammers: Banks: Economy. [Electronic resource] // Access mode: http://Lenta. $\mathrm{ru} /$ news/2020/12/24/crime/ (date of appeal - August 16, 2021).

For citation: Gareev M.F. Confiscation of property as a criminal punishment: article // Legal thought. 2021 . No. 3 (123). P. 72-80.

DOI: $10.47905 /$ MATGIP.2021.123.3.008

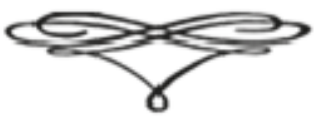




\title{
УдК 340 \\ ББК 67.0 \\ DOI: $10.47905 /$ MATGIP.2021.123.3.004
}

\section{ГосуАарственная НАЕОлоГНЯ КаК ОснОВа ПрЕАУПОЕЖАЕННЯ ПрЕСТТПКЕННЙ}

\begin{abstract}
M.Ф. Гареєв
Аннотация. В данной статье предлагается разработать государственную идеологию, одной из приоритетных задач которой должно выступить предупреждение преступности и иных противоправных деяний. В основе государственной идеомогии предмагается заложить традиционные морально-нравственные ценности и чувство патриотизма. Дмя предупреждения преступности и иных противоправных деяний предлагается законодательно закрепить государственную идеологию в Конституции Российской Федерации. Государственная идеология должна стать частью правовой жизни и правовой политики, вкАючая уголовно-правовую политику, а также выступить в качестве меры уголовно-правового воздействия.

К^ючевые слова: государственная идеология, морально-нравственные устои общества, правовая политика, правовая жизнь, правовое воздействие, Конституция Российской Федерации, предупреждение преступности, уголовное законодательство, меры уголовно-правового воздействия.
\end{abstract}

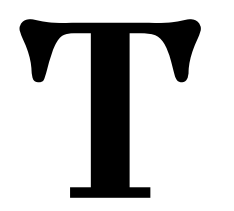

яжелым потрясением для многих наших сограждан стали трагические события 11 мая 2021 г. школе № 175 в городе Казань Республики Татарстан, когда бывший выпускник Ильназ Галявиев совершил убийство девятерых учеников и двух учителей. Более двух десятков детей получили ранения разцичной степени тяжести [1].

Казанская трагедия стала точным повторением трагедии 17 октября 2018 года, когда студент Керченского политехнического комледжа, распоможенного в г. Керчь Республики Крым, Владислав Росляков устроиц взрыв и стрельбу в этом учебном заведении. В результате этой трагедии погибли 21 человек [2]. ер

Обе трагедии совпали в деталях: одинаковый возраст стрелков, оба воспользовались боеприпасами повышенной поражаемости, использовали самодельные взрывные устройства. Совпал их психологический портрет: оба тихие, доброжелательные, отмечались примерным поведением. Объединяет их даже склонность к суициду, что должно также послужить предметом пристального внимания дмя разработки дальнейших мер предупредительного характера [3].

На фоне трагических событий возникают закономерные вопросы: почему подобное стало возможным? Каковы причины двух трагических событий, повторившихся даже в деталях? И самый главный вопрос: почему в недавном советском прошлом подобных трагедий не случалось?

* Гареев Марат Фаизович, доцент Юридического института (Санкт - Петербург), кандидат юридических наук. E-mail: gareeff.marat2013@yandex.ru 
Происшедшие события указывают на необходимость тщательного и глубокого их исследования, выявления широкого спектра проблем, порождающих подобные преступцения, разработки мер предупредитецьного характера. Однако, весьма широкий спектр проблем, способствующих трагическим событиям, не позволяют в рамках одной публикации рассмотреть их в полном объеме, поэтому остановимся только на ключевых моментах.

При обращении к советскому прошлому нашей страны приходишь к выводу, что подобного рода преступные деяния не могми возникнуть в симу ряда объективных причин. Большинству советских школьников даже в голову не могмо прийти оскорбить учителя, не говоря уже о совершении массового убийства в стенах родного учебного заведения. Невозможно бымо даже представить, что в советской школе встал бы вопрос об организации вооруженной охраны, это выглядемо бы просто дикостью.

Обеспечение безопасности в советский период гарантировалось поможительными морально-нравственными устоями основной части общества, которые закладывалось в человека почти с самого рождения. Отсутствовали всякие предпосылки дмя подобных чудовищных преступлений, поскольку продуманная система идеологического воздействия способствовала обеспечению безопасности не только учебных заведений, но и многих общественных мест. Вместо охранника с тревожной кнопкой советские ученики сами обеспечивали порядок. На входе в школу организовывалось дежурство учеников средних и старших кцассов только дмя того, чтобы никто из учащихся не прошел без сменной обуви, поскольку в классах и рекреациях школ чистота поддерживалась самими учащимися.

При этом о возникновении немотивированной агрессии не могло быть речи. Даже гардероб быц предоставцен самим ученикам, где они сами вешали свою одежду. Основной акцент учебно-воспитательного процесса был построен на привитии навыков и умений, основанных на самодисципмине и самокритике.

В учебных заведениях, начиная со школы и заканчивая вузами, a также на предприятиях и в организациях велась системная идеологическая работа по формированию положительных морально-нравственных ус-

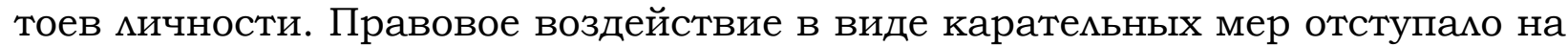
второй план. Огромную роль в формировании морали и нравственности мичности играл комлектив, который воздействовал на каждого его члена посредством внушения чувства стыда за совершение проступков, а в кол-

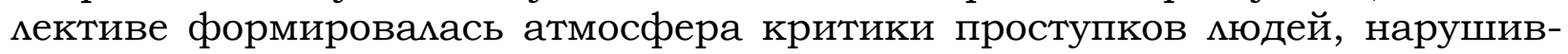
ших правила поведения, установленные в советском обществе [4].

В настоящее время часто встречаются случаи огульной критики нашего советского прошиого. Безусловно, советское общество было не идеальным, в нём были свои недостатки. Имели место преступцения, представцяющие повышенную общественную опасность. Однако подобного рода преступные проявления носили единичный характер, являлись редкостью, искцючением из правиц, а возможность керченской и казанской трагедий вообще исключалась. 
Как показывают вышеописанные трагические события, в современной России на нынешнем этапе особую актуальность приобретает задача уменьшения преступности и удержание ее на социально приемлемом уровне. Огромную роль для предупреждения преступных деяний домжно сыграть общественное осуждение, ставшее сегодня, к сожалению, формальностью. Мало того, сейчас нередко преступные деяния, посягающие даже на жизнь мюдей, становятся предметом дмя подражания.

Особую настороженность должен вызвать факт возрастания поклонников казанского стрелка Ильназа Галявиева. Буквально через сутки после казанской трагедии первое сообщение о подражании пришло из Благовещенска. Там силовикам пришлось эвакуировать школу № 27, а потом искать и задерживать подростка - ученика школы. Он написал в соцсетях, что "сделает то же самое, что и в Казани". В сети Интернет появцяются даже фанаты Галявиева, совершившего чудовищное преступление [5].

Подобного рода трагические события порождают размичные предможения по их предупреждению. Однако, они в основном сводятся к обеспечению безопасности учебных заведений в виде технической оснащенности и вооруженной охраны [6]. На фоне возрастания поклонников Галявиева, предлагаемые меры будут носить разовый характер, и в дальнейшем не исключат возможности повторения данных трагедий. Не смогма остановить казанскую трагедию широкомасштабная система видеонаблюдения, признанная одна из мучших [7].

Как показывает опыт Советского Союза, дмя предупреждения преступных явцений необходимо сформировать общественное сознание, основой которого явцяются мораль и нравственность. Возможность её внедрения представцяется возможной посредством государственной идеологии и формирования последовательной правовой политики.

Об эффективности советской системы предупреждения преступности встречается информация в ряде исследований. В частности, М.В. Бавсун отмечает, что “... в советский период развития уголовно-правового воздействия была создана достаточно гибкая система предупреждения преступмений. Система эта, в первую очередь, основывалась на стабильности сложившихся в обществе отношений, мощной идеологии, нормах морали и этики, позволявших более разносторонне и эффективно воздействовать

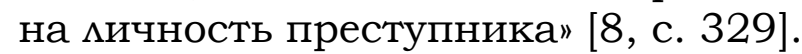

Констатируя фракт эффективной системы противодействия преступности в советский период, данный автор основное внимание концентрирует только на уголовно-правовых аспектах рассматриваемой пробцемы. В свою очередь, исследуемая проблема выходит далеко за рамки уголовно-правовых отношений и охватывает обширный круг проблем, на которые необходимо обратить внимание при разработке мер, направленных на противодействие преступности.

Формирование и реализация государственной политики должны осуществляться в соответствии с правовой политикой российского государства, одним из элементов которой является уголовно-правовая политика. В рамках этой политики разрабатываются меры уголовно-правового воздействия, направленные на предупреждение преступных явмений. 
При обращении к филологическим аспектам понятие "воздействие или воздействовать" раскрывается как "оказать влияние, добиться (ими добиваться) необходимого резумьтата" [9, с. 92].

В свою очередь, меры уголовно-правового воздействия, направленные на усиление в них карательного потенциала, имеют опредеменные пределы. Это обусловлено тем, что отдельные мица, склонные к совершению преступлений, со временем из-за привыкания к ним перестают их воспринимать. Данные доводы обосновываются статистическими данными о совершенных кражах. Обращение к данному виду преступления обусловлено его распространенностью и характерностью дия всех исторических эпох. Так, в 1989 г. в СССР с населением в 250 млн. человек было совершено 1142142 кражи чужого имущества [10, с. 66-68], в 2009 г. в России с населением около 140 млн. человек - 1188574 кражи $[11$, с. 8]. При значительном уменьшении населения России наблюдается количественный рос данного вида преступного деяния. Данные показатели указывает не только о существенном количественном росте преступности, но и об общем ухудшения криминальной ситуации.

О значительном ухудшении в нашей стране криминальной ситуации, по сравнению с советским периодом, указывает существенный рост матентных преступцений. О качественном ухудшении преступности указывает также рост матентных убийств, которые в общем массиве преступных деяний занимают значитемьное место [12].

На ограниченность карательного потенциала мер уголовно-правового воздействия указывает законотворческая и правоприменительная практика. В качестве примера обратимся к максимальной санкции статьи УК РФ, предусматривающей ответственность за совершение "простой" кражи (при отсутствии квалифицирующих признаков), которая с советских времен не подвергалась изменениям. В редакции УК РФСФР 1989 г. и в ныне действующем УК РФ максимальная санкция установлена в виде двух мет мишения свободы. Дальнейшее усиление ответственности за данный вид преступления может быть не только бесполезным, но социально вредным, сведя к минимуму предупредительный потенциал. Психологическая сущность преступного поведения такова, что усиление карательного потенциала со временем перестает восприниматься мицом, совершившим преступное деяние.

Действенным средством, направленным на снижение преступности, как показывает советский опыт, были бы разработка и внедрение комплексной системы мер правового воздействия на граждан, выходящих дамеко за рамки уголовного законодательства.

По четкому опредемению С.А. Комарова, правовое воздействие должно выступить как "результативное, нормативно-организационное влияние на общественные отношения как специальной системы собственно правовых средств (норм права, правоотношений, актов реализации и применения), так и иных правовых явлений (правосознания, правовой культуры, правовых принципов, правотворческого процесса, правовой политики)" [13, с. 490].

В продолжение развития данной идеи С.А. Комарова следует отметить, что, результатом правового воздействия домжно быть формирование 
положительных морально-нравственных качеств мичности в рамках внедрения комплексных мер предупредительного характера, направленных на предупреждение преступной деятемьности.

О необходимости комплексного подхода, направленного на выработку мер превентивного характера и ограниченности мер карательного воздействия указывает М.В. Бавсун. Он отметил: “... несомненным является и тот фракт, что при отсутствии остальных составляющих в виде качественного смежного законодательства, экономической и политической стабильности, высоких норм морали, ярко выраженной идеологии и, не в последнюю очередь, трезвости общества, добиться позитивного результата в борьбе с преступностью нельзя, какими бы ни были наказание и иные меры воздействия" [8, с. 329-330].

Обращаясь к советскому опыту, можно отметить, что основой дмя предупреждения преступлений в советский период выступала коммунистическая идеология, которая до ее монтажа в определенной степени имела свою эффективность, формируя положительные моральные и нравственные устои советского общества и государства, позволяя удерживать преступность на социально приемлемом уровне.

Дия разработки положительных морально-нравственных качеств мичности необходимо выработать государственную идеологию, которая в настоящее время у российского государства полностью отсутствует.

Законодательное внедрение и закрепление государственной идеологии позволит не только сдерживать уровень преступности на социально приемлемом уровне, но и оказывать положительное влияние на наиболее кАючевые сферы общества и государства, к которому также относится боеспособность армии. Ярким примером может служить опыт Корейской Народной Демократической Республики, которая при строительстве государственной идеологии за основу взяла советский опыт и с учетом национальных особенностей успешно ее применяет. Один из источников указывает: «По оценкам иностранных разведок, несмотря на международные санкции, слабую экономику и военную промышленность, вооруженные силы КНДР остаются одними из самых боеспособных в мире. Во многом это стало возможно благодаря двум идеологическим принципам, на которых строится северокорейская внутренняя политика: Чучхе - то есть "Опора на собственные силы" - и "Сонгун" - «Все для армии" [14].

Применительно к российским реалиям, одной из приоритетных направлений идеологии государства домжно стать реализация предупредительной функции уголовного законодательства, установленная ст. 2 УК РФ. При этом предупредительная функция государственной идеологии должна выходить не только за пределы уголовного права, но и иных отраслей права (уголовно-процессуального, уголовно-исполнительного и т.д.). Изначально строительство государственной идеологии должно носить концептуальный и комплексный характер, основываться на фрормировании положительных морально-нравственных устоев в обществе, не ограничиваясь правовой сферой. Одним из примеров идеологического воздействия, направменного на формирование положительных моральных качеств советского человека, может служить тимуровское движение, когда дети оказывали по- 
сильную помощь пожилым Аюдям и в процессе оказания помощи, у них вырабатывались уважение к старшему поколению и чувство сострадания. Впоследствии это позвоцимо свести к минимуму преступные посягательства в отношении престарелых граждан.

С фрилософрккой точки зрения идеологией признается система взгля-

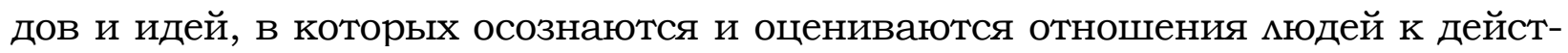
вительности и друг к другу, социальные пробцемы и конфликты, а также содержатся цели (программы) социальной деятельности, направленной на закрепление или изменение (развитие) данных общественных отношений [15].

В политологии под идеологией понимается система взглядов и идей, в которых выражается отношение к той или иной действительности, взгляды, интересы, цели, намерения, умонастроения [16, с. 113-114].

Различные подходы к определению идеологии свидетельствуют о том, что данное понятие охватывает более значительный круг общественных отношений и не ограничивается политической сферой.

В основе положительных морально-нравственных установок мичности, как фундамента идеологии российского государства, должны выступить традиционные культурные и религиозные воззрения многонационального народа нашей страны. При этом недопустимо строить идеоцогию государства, основываясь только на одной религии, поскольку в условиях многоконфессионального государства, каковым явцяется Российская Федерация, доминирование одного религиозного мировоззрения в состоянии реально разжечь религиозную и национальную вражду в российском обществе. Тем более, внутри самих конфессий присутствуют противоречия мировоззренческого характера, приобретая время от времени особую остроту [17]. Вырабатывая государственную идеологию, следует заимствовать по-

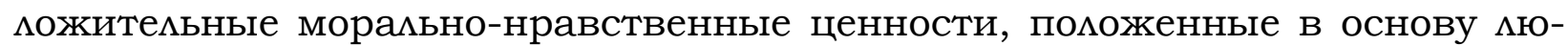
бой религии, без указания на конфессиональную принадлежность.

Внедрение государственной идеологии должно осуществцяться как в ходе законотворческой деятельности, так и в процессе формирования правовой политики.

В митературе под правовой политикой понимается деятельность органов государства и институтов гражданского общества по выработке стратегии и тактики правового регулирования, созданию эффективного механизма правового регулирования, по эффективному использованию юридических средств в интересах достижения таких целей, как наиболее полное обеспечение прав и свобод человека и гражданина, формирование правовой культуры и правовой жизни общества и кичности [18, с. 42]. Правовая жизнь, таким образом, является объектом правовой политики, представцяет собой одновременно истоки и сферу проявцения такой политики $[18$, с. 47$]$.

В то же время очевидно, что государственную идеологию в современных реалиях невозможно строить на политических идеях и взглядах, имевших место в советском государстве, поскоцьку по истечении более трех десятков мет у мюдей кардинально изменимось мировоззрение. Тем бомее, недопустимо ее строить на основе господства политических взглядов 
только какой-цибо одной партии, так как со временем доминирование одной партии приведет к ее стагнации.

Одновременно следует понимать, что формирование государственной идеологии - это работа не одного дня, а, скорее всего, десятицетий, построение которой представляется возможной осуществить только после проведения кардинальных преобразований в социально-экономической сфере российского государства. Такие преобразования должны коснуться обширного круга сфер жизнедеятельности государства и общества, включая как судебную и правоохранительную деятельность, так и деятельность государственного аппарата.

В идеале, государственная идеология должна стать эффективным средством противодействия преступному поведению мичности не за страх перед наказанием или иными формами карательного воздействия, а из-за сознательного неприятия гражданами преступного или иного асоциально поведения. У большинства мюдей домжно сформироваться негативное от-

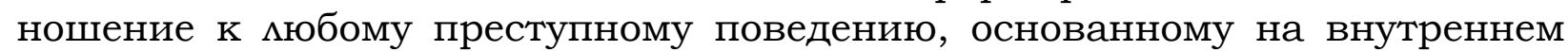
убеждении. Только подобным образом российскому обществу удастся остановить не только убийц, подобных Росляковым и Галявиевым, но и «загнать" преступность в социально приемлемые рамки.

С учетом отсутствия в российском государстве государственной идеомогии, возникает необходимость ее законодательного закрепления в Основном законе. Об отсутствии государственной идеологии указывает статья 13 Конституции Российской Федерации, поскольку в положениях части 1 и 2 данной нормы прописано об идеологическом многообразии и недопустимости установления никакой идеологии в качестве государственной или обязательной.

По этой причине предлагается ст. 13 Конституции РФ изложить в следующей редакции: "В Российской Федерации устанавцивается государственная идеология" (часть 1).

В ч. 2 данной нормы Конституции РФ предмагается закрепить следующее: "Государственная идеология строится на гуманизме, человеколюбии, патриотизме и иных традиционных для российского общества положительных моральных и нравственных устоях, выработанных предыдущими покомениями многонационального народа России на основе традиционных культурных и религиозных воззрений». В ч. 3 ст. 13 Конституции РФ предусмотреть: "запрещается строительство государственной идеологии на господстве одной религиозной конфессии или религиозного учения". При этом части 3, 4 и 5 ст. 13 Конституции РФ изцожить в частях 4, 5 и 6 соответственно.

Правовыми предпосылками для создания государственной идеологии, основанной на традиционных культурных и религиозных воззрениях, на морали и нравственности может служить ч. 2 ст. 67.1 Конституции РФ, в которой указано, что "Российская Федерация, объединенная тысячелетней историей, сохраняя память предков, передавших нам идеалы и веру в Бога, а также преемственность в развитии Российского государства, признает исторически сложившееся государственное единство».

Отдельное внимание в российской государственной идеологии домжно быть уделено чувству патриотизма, который помог выстоять в тяжелые 
годы испытаний нашего народа и одержать победу в борьбе с агрессорами, нападению которых наше Отечество подвергалось многократно. Внедрение чувства патриотизма, как показывает советский опыт идеоцогического воздействия, который выходиц за рамки правой сферы, неоднократно доказал свою эффективность. Оно, например, выразилось в создании художественных и документальных фильмов о Великой Отечественной войне, конференциях, встречах с участниками боевых действий и т.д.

Комплексное применение идеологического воздействия повысит эффективность предупредительных мер преступности, поскольку в результате этого будут задействованы такие каналы, как: мации);

- информационный (право, как разновидность нормативной инфор-

- ценностно-ориентированный (воздействие права как социальной ценности на общественные отношения) [13, с. 492].

Примером положительного идеологического воздействия являются такие общеизвестные христианские заповеди, как "не убий", "не укради", "не прелюбодействуй", "не произноси можного свидетельства на ближнего твоего" и др.

Вызывают определенный интерес отдемьные религиозные постулаты в исламе. Одним из них является аят, разрешающий самооборону: "Тем, против кого ведут войну, Дозволено сражаться, - Ведь им (несправедииво) причиними змо, А потому Ацмах, поистине, могуч помочь им" (22:39) [19, c. 366]. Как крайнюю меру оказания сопротивления при преследовании агрессии в исламе отмечает Тарик Рамадан: “Новообразовавшаяся община верующих (мусумьман - примечание автора) стояла перед выбором - выжить или быть уничтоженными. В такой ситуации у них не было иного выбора, кроме самозащиты" [20, с. 53].

Среди провозглашенных принципов самообороны в исламе положительным является то, что они домжны быть равнозначны методам агрессора: «Если вы подвергаете их наказанию, то наказывайте их так, как они наказывали вас. Но если вы проявите терпение, то так будет мучше для терпемивых" (16:126) [19, с. 310]. О необходимости прекращения мюбых действий, причиняющих вред при самообороне, в случае предможения мира со стороны нападающего указывают следующие изречения: "Если они склоняются к миру, ты тоже склоняйся к миру и уповая на Господа. Воистину, Он - Слышащий, Знающий" (8:61) [19, с. 213].

Религиозные каноны о самообороне закладывают психологические основы мичности, позволяющие избегать конфликтных ситуаций, а при их возникновении, нацеливает на их разрешение в мирном русле.

В ряде государств система религиозных канонов в исламе, основан-

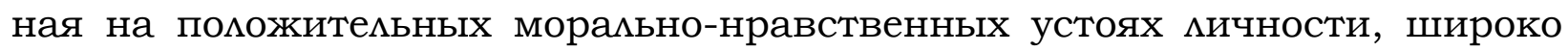
внедряемых в общественные и государственные институты, позволяет сдерживать преступность на социально приемлемом, низком уровне.

В пользу изможенных доводов свидетельствует рейтинг безопасности стран 2021 г., из которого следует, что арабские государства имеют самый высокий рейтинг безопасности в мире. Первое место в этом рейтинге заням Катар, индекс преступности которого составцяет всего 12,29, а индекс 
безопасности 87,71. Второе место в мире в рейтинге безопасных государств занимают Объединенные Арабские Эмираты, где индекс преступности составляет 15,35, а индекс безопасности 84,65. Третье место принадлежит Оману, в которой индекс преступности на уровне 20,26, а индекс безопасности 79,74 [21].

Таким образом, национальное, религиозное и культурное многообразие народов, населяющих Российскую Федерации может сыграть огромную роль при разработке государственной идеологии. Материальным воплощением государственной идеологии могут быть не только правовое воздействие, но и формы идеологического воздействия на граждан, применяемые комплексно, направленные на формирование правопослушного поведения. Идеологическая основа российского государства подлежит законодательному закреплению в Конституции России, выступающей своеобразным фундаментом не только для других отраслей права, но и ориентиром в дальнейшем в законотворческой и правоприменительной деятельности. Формирование морально-нравственных религиозных взглядов и убеждений должны представляться как нейтральное, как общее культурное и религиозное достояние многонационального российского народа.

\section{Библиографический список}

1. 7 минут кошмара. Восстановлена хроника расстрела в казанской школе. [Эмектронный ресурс] //Режим доступа: https://anews.com/136497379-7 (дата обращения - 28.07.2021).

2. Керченский расстрел год спустя: загадка Рослякова и трагедия выжившей. [Эмектронный ресурс] //Режим доступа: https://anews.com/novosti/ 118468220 (дата обращения - 28.07.2021).

3. "Я попытался совершить суицид, перекусив своими зубами артерию": допрос казанского стрелка. [Эмектронный ресурс] //Режим доступа: https:// sharij.net (дата обращения - 28.07.2021).

4. Автор делится собственным опытом обучения в советской школе.

5. См.: Трагедия в Казани: откуда у стрелка Галявиева появилась целая армия фанатов и подражателей. [Эмектронный ресурс] //Режим доступа: https:// prokazan.ru/news/view/146732 (дата обращения - 28.07.2021).

6. Владимир Жириновский на 1 Канале про стрельбу в Казанской школе. [Эмектронный ресурс] //Режим доступа: https://yandex.ru/video/preview/?text (дата обращения - 27 июля 2021 г.).

7. Стрельба в Казани обрастает фигурантами - Происшествия - Коммерсантъ. [Эмектронный ресурс] //Режим доступа: https://www.kommersant.ru/doc/ 4889901 (дата обращения - 28 июля 2021 г.).

8. Бавсун М.В. Уголовно-правовое воздействие: идеология, цели и средства и реализации: дисс. док... юрид. наук, - Омск, 2013. - 248 с.

9. Ожегов С.И., Шведова Н.Ю. Толковый словарь //Российская академия наук. Институт русского языка им. В.В. Виноградова. - 4-е изд., дополненное. М.: ООО «ИТИ Технология», 2006. - 944 с.

10. Преступность и правонарушения в СССР. 1990: Сборник статей. - М., 1991. $-128 \mathrm{c}$.

11. Состояние правопорядка в Российской Федерации и основные результаты деятельности органов внутренних дел и внутренних войск в 2009 году: аналитические материалы. - М., 2010. - 112 с. 
12. Богданова $\Lambda$. Выявцение матентных убийств в ходе прокурорских проверок / /Уголовное право. - 2011. - № 5. - С. 109-114.

13. Комаров С.А. Общая теория государства и права. 8-е изд. - СПб.: Юридический институт, 2012. - 506 с.

14. Тайные армии Северной Кореи: «ядерные" смертники и рыбья кровь MK. [Эмектронный ресурс] //Режим доступа: https://www.mk.politic (дата обращения - 29 июля 2021 г.).

15. Краткий словарь философских терминов. [Электронный ресурс] // Pежим доступа: https://nenuda.ru/html. (дата обращения - 29 июля 2021 г.).

16. Политология. Энциклопедический словарь. //Изд-во Московского коммерческого университета. - М., 1993. - 431 с.

17. Равиць Гайнутдин обвиния муфтия Татарстана в сектантстве [Электронный ресурс] //Режим доступа: https: //www.business-gazeta.ru/news/505188 (дата обращения - 29 июля 2021 г.).

18. Малько А.В. Теория правовой политики: монография. - М.: Юрлитинформ, 2012. - 328 с.

19. Коран. Перевод смыслов и комментарии Иман Валерии Прохоровой. М.: Рипол классик, 2018. - 800 с.

20. Рамадан Тарик. Ислам: прошлое и настоящее /пер. с англ. З. Нестеровой. - М.: Азбука-Аттику, Коһибри, 2017. - 287 с.

21. Рейтинг безопасных стран 2021 г. Crime Index by Country [Электронный pecyp] //Режим доступа: https://ekec.ru/rejting-besopasnosti-stran-2021-godacrime-index-by-country/ (c) Turazbuka NEWS ${ }^{\mathrm{TM}}$ (дата обращения - 29 июля 2021 г.).

Дия цитирования: Гареев М.Ф. Государственная идеология как основа предупреждения преступлений: статья // Юридическая мысль. 2021 . № 3 (123). С. 81-90.

DOI: $10.47905 /$ MATGIP.2021.123.3.004

\section{State ideology as basis for crime prevention}

\section{Marat F. Gareev *}

Annotation. This article proposes to develop a state ideology, one of the priority tasks of which should be the prevention of crime and other illegal acts. It is proposed to lay the traditional moral and ethical values and a sense of patriotism at the basis of the state ideology. To prevent crime and other unlawful acts, it is proposed to legislate the state ideology in the Constitution of the Russian Federation. The state ideology should become a part of legal life and legal policy, including criminal law policy, and also act as a measure of criminal law influence.

Key words: state ideology, moral and ethical foundations of society, legal policy, legal life, legal impact, Constitution of the Russian Federation, crime prevention, criminal legislation, measures of criminal law.

A grave shock for many of our fellow citizens was the tragic events of May 11, 2021 at school No. 175 in the city of Kazan, Republic of Tatarstan, when a former graduate, Ilnaz Galyaviev, murdered nine students and two teachers. More than two dozen children were injured of varying severity [1].

* Gareev Marat Faizovich, associate professor of the Law Institute (St. Petersburg), candidate of legal sciences. E-mail: gareeff.marat2013@yandex.ru 
The Kazan tragedy became an exact repetition of the tragedy of October 17, 2018, when Vladislav Roslyakov, a student of the Kerch Polytechnic College located in the city of Kerch of the Republic of Crimea, set up an explosion and shooting at this educational institution. As a result of this tragedy, 21 people died [2].

Both tragedies coincided in detail: the same age of the shooters, both used ammunition with increased lethality, used improvised explosive devices. Their psychological portrait coincided: both were quiet, benevolent, marked by exemplary behavior. They are even united by a tendency to suicide, which should also be the subject of close attention to develop further preventive measures [3].

Against the background of tragic events, logical questions arise: why did this become possible? What are the reasons for the two tragic events that repeated themselves even in detail? And the most important question: why did not such tragedies happen in the recent Soviet past?

The events that have taken place indicate the need for a thorough and indepth study of them, identifying a wide range of problems that give rise to such crimes, and developing preventive measures. However, a very wide range of problems contributing to tragic events do not allow considering them in full within the framework of one publication, so we will focus only on the key points.

When referring to the Soviet past of our country, one comes to the conclusion that such criminal acts could not arise due to a number of objective reasons. Most Soviet schoolchildren could not even think of offending a teacher, let alone committing a massacre within the walls of their own educational institution. It was impossible even to imagine that in the Soviet school the question of organizing an armed guard would have arisen, it would have looked just savage.

Ensuring security in the Soviet period was guaranteed by the positive moral and ethical foundations of the main part of society, which were embedded in a person almost from birth. There were no prerequisites for such monstrous crimes, since a well-thought-out system of ideological influence helped to ensure the safety of not only educational institutions, but also many public places. Instead of a security guard with a panic button, Soviet students themselves ensured order. At the entrance to the school, a watch was organized for middle and high school students only so that none of the students went through without changing shoes, since in the classrooms and recreation of the schools, cleanliness was maintained by the students themselves.

At the same time, the occurrence of unmotivated aggression was out of the question. Even the wardrobe was provided by the students themselves, where they hung their own clothes. The main emphasis of the educational process was built on the inculcation of skills and abilities based on selfdiscipline and self-criticism.

In educational institutions, from school to universities, as well as in enterprises and organizations, systematic ideological work was carried out to form positive moral and ethical foundations of the individual. Legal impact in the form of punitive measures receded into the background. A huge role in the 
formation of morality and morality of the individual was played by the collective, which influenced each of its members by instilling a sense of shame for committing misconduct, and an atmosphere of criticism of the misdeeds of people who violated the rules of behavior established in Soviet society was formed in the collective [4].

At the present time, there are often cases of indiscriminate criticism of our Soviet past. Of course, Soviet society was not ideal, it had its own shortcomings. There have been crimes that pose an increased public danger. However, this kind of criminal manifestations were of a single nature, were rare, an exception to the rule, and the possibility of Kerch and Kazan tragedies was completely ruled out.

As the above-described tragic events show, in modern Russia at the current stage, the task of reducing crime and keeping it at a socially acceptable level is acquiring special urgency. Public condemnation, which, unfortunately, has become a formality today, should play a huge role in preventing criminal acts. Moreover, now often criminal acts that even infringe on the lives of people become a subject for imitation.

The fact that the admirers of the Kazan shooter Ilnaz Galyaviev are growing should be of particular concern. Literally a day after the Kazan tragedy, the first message about imitation came from Blagoveshchensk. There, the security forces had to evacuate school No. 27, and then look for and detain a teenager a student of the school. He wrote on social networks that "he will do the same as in Kazan". Even fans of Galyaviev, who committed a heinous crime, appear on the Internet [5].

Tragic events of this kind give rise to various proposals for their prevention. However, they basically boil down to ensuring the security of educational institutions in the form of technical equipment and armed guards [6]. Against the background of the growth of Galyaviev's admirers, the proposed measures will be one-time in nature, and in the future they will not exclude the possibility of a repetition of these tragedies. The large-scale video surveillance system, recognized as one of the best, could not stop the Kazan tragedy [7].

As the experience of the Soviet Union shows, in order to prevent criminal phenomena, it is necessary to form public consciousness, the basis of which is morality and ethics. The possibility of its implementation seems possible through the state ideology and the formation of a consistent legal policy.

There is information about the effectiveness of the Soviet crime prevention system in a number of studies. In particular, M.V. Bavsun notes that “... in the Soviet period of development of criminal law, a fairly flexible system of crime prevention was created. This system, first of all, was based on the stability of the relations prevailing in society, powerful ideology, norms of morality and ethics, which allowed more versatile and effective influence on the personality of the criminal" [8, p. 329].

Stating the fact of an effective system for combating crime in the Soviet period, this author focuses only on the criminal-legal aspects of the problem under consideration. In turn, the problem under study goes far beyond the framework of criminal law relations and covers a wide range of problems that need to be paid attention to when developing measures aimed at combating crime. 
The formation and implementation of state policy should be carried out in accordance with the legal policy of the Russian state, one of the elements of which is the criminal law policy. Within the framework of this policy, measures of criminal law are being developed, aimed at preventing criminal phenomena.

When referring to the philological aspects, the concept of "influence or influence" is revealed as "to influence, achieve (or achieve) the desired result" [9, p. 92].

In turn, the measures of criminal law aimed at strengthening their punitive potential have certain limits. This is due to the fact that individuals who are prone to committing crimes, over time, due to addiction to them, cease to perceive them. These arguments are substantiated by statistical data on thefts committed. The appeal to this type of crime is due to its prevalence and specificity for all historical eras. So, in 1989 in the USSR with a population of 250 million people, $1,142,142$ thefts of someone else's property were committed [10, p. 66-68], in 2009 in Russia with a population of about 140 million people $1,188,574$ thefts [11, p. eight]. With a significant decrease in the population of Russia, there is a quantitative increase in this type of criminal act. These indicators indicate not only a significant quantitative increase in crime, but also a general deterioration in the criminal situation.

A significant deterioration in the criminal situation in our country, compared with the Soviet period, is indicated by a significant increase in latent crimes. The qualitative deterioration of crime is also indicated by the growth of latent murders, which occupy a significant place in the total array of criminal acts [12].

Legislative and law enforcement practice points to the limited punitive potential of criminal law measures. As an example, let us turn to the maximum sanction of the article of the Criminal Code of the Russian Federation, which provides for liability for committing "simple" theft (in the absence of qualifying signs), which has not been changed since Soviet times. In the version of the Criminal Code of the RFSFR in 1989 and in the current Criminal Code of the Russian Federation, the maximum sanction is set in the form of two years in prison. Further strengthening of responsibility for this type of crime can be not only useless, but socially harmful, minimizing the preventive potential. The psychological essence of criminal behavior is such that the strengthening of the punitive potential eventually ceases to be perceived by the person who committed the criminal act.

An effective means aimed at reducing crime, as the Soviet experience shows, would be the development and implementation of a comprehensive system of measures of legal influence on citizens that go far beyond the framework of criminal legislation.

According to the clear definition of S.A. Komarov, the legal impact should act as "effective, regulatory and organizational influence on public relations as a special system of legal means proper (norms of law, legal relations, acts of implementation and application), and other legal phenomena (legal awareness, legal culture, legal principles, law-making process, legal policy)" [13, p. 490].

Continuing the development of this idea, S.A. Komarov, it should be noted that the result of legal impact should be the formation of positive moral 
and moral qualities of the individual within the framework of the implementation of comprehensive preventive measures aimed at preventing criminal activity.

M.V. Bavsun noted: "... there is no doubt the fact that in the absence of other components in the form of high-quality related legislation, economic and political stability, high moral standards, a pronounced ideology and, last but not least, the sobriety of society, to achieve a positive result in the fight against crime is impossible, whatever the punishment and other measures of influence" [8, p. 329-330].

Referring to the Soviet experience, it can be noted that the basis for the prevention of crimes in the Soviet period was the communist ideology, which before its installation had its effectiveness to a certain extent, forming the positive moral and ethical foundations of Soviet society and the state, allowing to keep crime at a socially acceptable level.

To develop positive moral and ethical qualities of the individual, it is necessary to develop a state ideology, which is currently completely absent from the Russian state.

The legislative implementation and consolidation of the state ideology will allow not only to restrain the crime rate at a socially acceptable level, but also to have a positive impact on the most key spheres of society and the state, which also includes the combat capability of the army. A striking example is the experience of the Democratic People's Republic of Korea, which, in building its state ideology, took the Soviet experience as a basis and, taking into account national characteristics, successfully applies it. One of the sources points out: "According to foreign intelligence, despite international sanctions, a weak economy and military industry, the DPRK's armed forces remain one of the most efficient in the world. In many ways, this became possible thanks to two ideological principles on which North Korean domestic policy is built: Juche - that is, "Self-reliance" - and "Songun" - "Everything for the army" [14].

With regard to Russian realities, one of the priority directions of the state ideology should be the implementation of the preventive function of criminal legislation, established by Art. 2 of the Criminal Code of the Russian Federation. At the same time, the preventive function of state ideology should go not only beyond the criminal law, but also other branches of law (criminal procedural, criminal executive, etc.). Initially, the construction of a state ideology should be conceptual and complex in nature, based on the formation of positive moral and ethical foundations in society, not being limited to the legal sphere. One example of an ideological influence aimed at the formation of positive moral qualities of a Soviet person is the Timurov movement, when children provided all possible help to the elderly and in the process of providing assistance, they developed respect for the older generation and a sense of compassion. Subsequently, this made it possible to minimize criminal attacks against the elderly.

From a philosophical point of view, ideology is a system of views and ideas, in which people's attitudes to reality and to each other, social problems and conflicts are recognized and evaluated, and also contains the goals (programs) of social activities aimed at consolidating or changing (developing) data of public relations [15]. 
In political science, ideology is understood as a system of views and ideas, which expresses the attitude to this or that reality, views, interests, goals, intentions, mentality of people, classes ... and so on [16, p. 113-114].

Different approaches to the definition of ideology indicate that this concept covers a wider range of social relations and is not limited to the political sphere.

The positive moral and ethical attitudes of the individual, as the foundation of the ideology of the Russian state, should be based on the traditional cultural and religious views of the multinational people of our country. At the same time, it is unacceptable to build the ideology of the state based on only one religion, since in the conditions of a multi-confessional state, such as the Russian Federation, the dominance of one religious worldview can really inflame religious and national enmity in Russian society. Moreover, within the confessions themselves there are contradictions of a worldview character, acquiring from time to time a special acuteness [17]. When developing a state ideology, one should borrow the positive moral and ethical values underlying any religion, without indicating confessional affiliation.

The introduction of state ideology should be carried out both in the course of legislative activity and in the process of forming legal policy.

In the literature, legal policy is understood as the activity of state bodies and civil society institutions in developing a strategy and tactics of legal regulation, creating an effective mechanism for legal regulation, in the effective use of legal means in the interests of achieving such goals as the fullest possible provision of human and civil rights and freedoms, the formation of legal culture and legal life of society and individuals [18, p. 42]. Legal life, thus, is an object of legal policy, is both the origins and the sphere of manifestation of such a policy $[18$, p. 47].

At the same time, it is obvious that in modern realities it is impossible to build state ideology on the political ideas and views that took place in the Soviet state, since after more than three decades, people have radically changed their worldview. Moreover, it is unacceptable to build it on the basis of the dominance of the political views of only one party, since over time the dominance of one party will lead to its stagnation.

At the same time, it should be understood that the formation of a state ideology is not a one-day work, but, most likely, decades, the construction of which seems possible to be carried out only after cardinal transformations in the socio-economic sphere of the Russian state have been carried out. Such transformations should affect a wide range of spheres of life of the state and society, including both judicial and law enforcement activities, and the activities of the state apparatus.

Ideally, the state ideology should become an effective means of counteracting the criminal behavior of an individual, not for fear of punishment or other forms of punitive influence, but because of the citizens' conscious rejection of criminal or other antisocial behavior. Most people should develop a negative attitude towards any criminal behavior based on inner conviction. Only in this way will Russian society be able to stop not only murderers like the Roslyakovs and Galyavievs, but also "drive" crime into a socially acceptable framework. 
Given the absence of state ideology in the Russian state, there is a need for its legislative consolidation in the Basic Law. The absence of state ideology is indicated by article 13 of the Constitution of the Russian Federation, since the provisions of parts 1 and 2 of this rule stipulate ideological diversity and the inadmissibility of establishing any ideology as state or mandatory.

For this reason, Art. 13 of the Constitution of the Russian Federation shall be stated as follows: "The state ideology is established in the Russian Federation" (part 1).

In part 2 of this norm of the Constitution of the Russian Federation, it is proposed to consolidate the following: "The state ideology is built on humanism, philanthropy, patriotism and other positive moral and ethical foundations traditional for Russian society, developed by previous generations of the multinational people of Russia on the basis of traditional cultural and religious views".

Part 3 of Art. 13 of the Constitution of the Russian Federation to provide: "it is prohibited to build a state ideology on the dominance of one religious denomination or religious doctrine". In this case, parts 3, 4 and 5 of Art. 13 of the Constitution of the Russian Federation shall be stated in parts 4, 5 and 6, respectively.

Part 2 of Art. 67.1 of the Constitution of the Russian Federation, which states that "the Russian Federation, united by a thousand-year history, preserving the memory of ancestors who passed on to us ideals and faith in God, as well as continuity in the development of the Russian state, recognizes the historically established state unity".

Special attention in the Russian state ideology should be paid to a sense of patriotism, which helped to withstand the difficult years of trials of our people and to win in the fight against aggressors, whose attacks our Fatherland was subjected to many times.

The introduction of a sense of patriotism, as the Soviet experience of ideological influence shows, which went beyond the right sphere, has repeatedly proved its effectiveness. For example, it was expressed in the creation of feature films and documentaries about the Great Patriotic War, conferences, meetings with combatants, etc.

The complex application of ideological influence will increase the effectiveness of preventive measures of crime, since as a result of this, such channels will be involved as:

- informational (law, as a kind of regulatory information);

- value-oriented (the impact of law as a social value on social relations) [13, p. 492].

An example of a positive ideological impact is such well-known Christian commandments as "Thou shalt not kill", "Thou shalt not steal", "Do not commit adultery", "Do not give false testimony against your neighbor", etc.

Certain religious postulates in Islam are of particular interest. One of them is the verse that permits self-defense: "Those against whom they are waging war, It is permissible to fight, - After all, they (unjustly) have been harmed, And therefore Allah is truly powerful to help them" $(22: 39)$ [19, p. 366]. As an extreme measure of resistance in the pursuit of aggression in Islam, Tariq Ramadan notes: "The newly formed community of believers (Muslims - author's 
note) faced a choice - to survive or to be destroyed. In such a situation, they had no choice but to defend themselves" [20, p. 53].

Among the proclaimed principles of self-defense in Islam, the positive is that they should be tantamount to the methods of the aggressor: "If you punish them, then punish them as they punished you. But if you show patience, then it will be better for the patient" (16: 126) [19, p. 310]. The following sayings indicate the need to stop any actions that cause harm in self-defense in the event of an offer of peace by the attacker: "If they lean toward peace, you also lean toward peace and trust in the Lord. Indeed, He is the Hearing, the Knowing" (8:61) [19, p. 213].

Religious canons on self-defense lay the psychological foundations of the personality, allowing to avoid conflict situations, and when they arise, aims at resolving them in a peaceful manner.

In a number of states, the system of religious canons in Islam, based on the positive moral and ethical foundations of the individual, is widely implemented in public and state institutions, allows to restrain crime at a socially acceptable, low level.

The above arguments are supported by the security rating of countries in 2021 , from which it follows that the Arab states have the highest security rating in the world. The first place in this ranking was taken by Qatar, which has a crime index of only 12.29 and a safety index of 87.71. The second place in the world in the ranking of safe states is occupied by the United Arab Emirates, where the crime index is 15.35 and the safety index is 84.65. The third place belongs to Oman, in which the crime index is at the level of 20.26, and the safety index is 79.74 [21].

Thus, the national, religious and cultural diversity of the peoples inhabiting the Russian Federation can play a huge role in the development of state ideology. The material embodiment of state ideology can be not only legal influence, but also forms of ideological influence on citizens, applied in a comprehensive manner, aimed at the formation of law-abiding behavior.

The ideological basis of the Russian state is subject to legislative consolidation in the Constitution of Russia, which serves as a kind of foundation not only for other branches of law, but also as a guideline in the future in legislative and law enforcement activities.

The formation of moral and ethical religious views and beliefs should be presented as neutral, as a common cultural and religious heritage of the multinational Russian people.

\section{Bibliographic list}

1. 7 minutes of a nightmare. The chronicle of the shooting in the Kazan school has been restored. [Electronic resource] // Access mode: https://anews.com/ 136497379-7 (date of access - 28.07.2021).

2. The Kerch execution a year later: the mystery of Roslyakov and the tragedy of the survivor. [Electronic resource] // Access mode: https://anews.com/novosti/ 118468220 (date of access - 07/28/2021).

3. "I tried to commit suicide by biting an artery with my teeth": interrogation of the Kazan shooter. [Electronic resource] // Access mode: https: // sharij.net (date of access - 28.07.2021). 
4. The author shares his own experience of teaching in the Soviet school.

5. See: Tragedy in Kazan: Where did the shooter Galyaviev got a whole army of fans and imitators from? [Electronic resource] // Access mode: https://prokazan.ru/ news/view/146732 (date of access - 07/28/2021).

6. Vladimir Zhirinovsky on Channel 1 about the shooting at the Kazan school. [Electronic resource] // Access mode: https://yandex.ru/video/preview/?text (date of access - July 27, 2021).

7. Shooting in Kazan is overgrown with persons involved - Accidents - Kommersant. [Electronic resource] // Access mode: https://www.kommersant.ru/doc/ 4889901 (date of appeal - July 28, 2021).

8. Bavsun M.V. Criminal law impact: ideology, goals and means and implementation: Diss. doc... jurid. Sciences. Omsk, 2013. 248 p.

9. Ozhegov S.I. and Shvedova N.Yu. Explanatory dictionary. //The Russian Academy of Sciences. Institute of the Russian language. V.V. Vinogradov. 4th ed., Supplemented. Moscow: OOO "ITI Technology", 2006. 944 p.

10. Crime and delinquency in the USSR. 1990: Collected papers. Moscow, 1991. $128 \mathrm{p}$.

11. The state of law and order in the Russian Federation and the main results of the activities of the internal affairs bodies and internal troops in 2009: analytical materials. Moscow, 2010. 112 p.

12. Bogdanova L. Identification of latent murders in the course of prosecutorial inspections // Criminal law. 2011. No. 5. P. 109-114.

13. Komarov S.A. General theory of state and law. 8th ed. Sankt-Petersburg: Legal Institute, 2012. 506 p.

14. Secret armies of North Korea: "nuclear" suicide bombers and fish blood MK. [Electronic resource] // Access mode: https: //www.mk.politic (date of access July 29, 2021).

15. A short dictionary of philosophical terms. [Electronic resource] // Access mode: https://nenuda.ru/html. (date of appeal - July 29, 2021).

16. Political science. Encyclopedic Dictionary. // Publishing house of the Moscow Commercial University. Moscow, 1993. 431 p.

17. Ravil Gainutdin accused the Mufti of Tatarstan of sectarianism [Electronic resource] // Access mode: https: //www.business-gazeta.ru/news/505188 (date of appeal - July 29, 2021).

18. Malko A.V. The theory of legal policy: monograph. Moscow: Yurlitinform, 2012. 328 p.

19. Koran. Translation of meanings and comments by Iman Valeria Prokhorova. Moscow: Ripol classic, 2018. 800 p.

20. Ramadan Tariq. Islam: past and present / per. from English Z. Nesterova. Moscow: Azbuka-Attiku, Colibri, 2017. 287 p.

21. Rating of safe countries 2021 Crime Index by Country [Electronic resource] // Access mode: https://ekec.ru/rejting-besopasnosti-stran-2021-goda-crime-index-bycountry / (C) Turazbuka NEWSTM (date of appeal - July 29, 2021).

For citation: Gareev M.F. State ideology as the basis for crime prevention: article // Legal thought. 2021. No. 3 (123). P. 90-98.

DOI: 10.47905 / MATGIP.2021.123.3.004

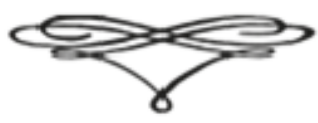




\title{
В ПОМОЩЬ ПРЕПОДАВАТЕАЮ
}

\section{Удк 343.98}

DOI: 10.47905/MATGIP.2021.123.3.005

\author{
Хекцня: \\ Вопросы повышення эффектнвностн \\ орГанНзацнн раБОТЫ САЕАСТВеннЫХ ОрГанОв \\ Gледственного комнтета Российской Федерацин
}

Ф.Н. Бастрыкнн*

\begin{abstract}
Аннотация. В данной мекции содержится предложения по повышению эффективности организации работы следственных органов Следственного комитета Российской Федерации на современном этапе. Автор отмечает, что во все времена успешная организация работы включая и следственные органы Следственного комитета, возможна только в результате систематического повышения уровня профессиональной подготовки, который достигается за счет использования размичных форм обучения.

Автор считает, что начинающему следователю, окончившему высшее учебное заведение нужно обеспечить такое вхождение в должность, которое позволит ему психологически и профессионально успешно начать работать, постепенно привыкнуть к нагрузкам при неукоснительном соблюдении служебной дисциплины, Присяги и Кодекса этики и служебного поведения.

КАючевые слова: эффективность, уголовное законодательство, уголовнопроцессуальное право, Следственный комитет, прокуратура, профессиональная подготовка и переподготовка.
\end{abstract}

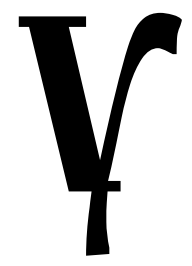

спешная организация работы следственных органов Следственного комитета возможна только в результате систематического повышения уровня профессиональной подготовки следователей, который достигается за счет использования различных форм обучения.

Следователям необходимо постоянно заботиться о рациональной, экономичной организации своей работы, не допускать необоснованного отвлечения от исполнения служебньх обязанностей. Важнейшим усмовием совершенствования деятельности следователей является изучение и практическое применение научных рекомендаций и передового опыта ведения следствия.

Вцадеть научными рекомендациями, передовыми приемами и методами работы обязан каждый работник следственных органов, для чего необходимо постоянно изучать информационные письма, обзоры, периодиче-

* Бастрыкин Александр Иванович, председатель Следственного комитета Российской Федерации, доктор юридических наук, профессор, Заскуженный юрист Российской Федерации. E-mail: lawinst-spb@mail.ru 
ские издания Следственного комитета и другую учебно-методическую митературу, внедрять изложенный в них опыт в собственную практику.

Известно, что важнейшими элементами организации следственной работы явцяются хорошо продуманное планирование работы и четко поставленный контроль. Отсутствие плана вызывает неоправданные потери рабочего времени, отвлекает следователей от выполнения прямых обязанностей, а бесконтрольность нередко порождает безответственность и приводит к продлению сроков и затягиванию следствия.

В связи с этим повседневная работа следователя должна выстраиваться системно и быть направлена на сокращение сроков производства по уголовным делам, улучшение качества следствия, обеспечение действенного процессуального контроля по защите прав и законных интересов граждан. В противном случае неоправданно диительные сроки следствия (как и продолжительные сроки исполнения судебных решений) станут поводом дия искового заявления о присуждении компенсации за нарушение права на судопроизводство в разумный срок.

Касаясь этого вопроса, следует отметить, что постановления о возбуждении ходатайств о продлении процессуальных сроков во многих случаях изготавливаются "по шаблону". Довод о необходимости проведения бомьшого количества следственных действий нередко употребцяется в них как штамп, также как и ссылка на то, что демо представляет особую сложность. В постановлениях следователей не приводится полная мотивировка обстоятельств, послуживших основанием дия возбуждения ходатайств о продмении процессуальных сроков.

Зачастую отсутствует чёткий план действий, который следует выполнить в течение запрашиваемого процессуального срока, в том числе с участием оперативных подразделений. Всё это является одной из причин того, что, несмотря на наши возросшие требования к ведомственному процессуальному контролю, количество уголовных дел, расследованных в срок свыше двух месяцев в 2016 году практически осталось на уровне 2015 года 43505 дем (11 мес. 2015 г. - 43 496). На 6,5\% возросло количество уголовных дем, возвращенных прокурором для производства дополнительного расследования (3 213, 11 мес. 2015 г. - 3 016). И это при том, что сокращение процессуальных сроков и улучшение качества следствия постоянно находятся в поле зрения и органов прокуратуры, которые все более принципиально осуществляют надзор за этими показателями следственной работы.

Подчеркну, что залог эффективности процессуального контроля - не в количестве контролеров и не в стремлении охватить весь объём процессуальной деятельности следователя, а в создании его продуманной системы, построению и надлежащей организации которой следует уделять повышенное внимание.

Важнейший вопрос организации работы следственных органов - закрепление молодых специалистов и адаптация выпускников юридических вузов. Почти 60\% наших следователей имеют опыт работы до 5 мет.

С такими молодыми кадрами мы работаем уже седьмой год и за это время следователями Следственного комитета проверены свыше 5 мимиионов сообщений о преступлении, возбуждено 808 тысяч уголовных дец. В суд 
направлено свыше 570 тысяч уголовных дем (572 299) на 640 тысяч обвиняемых.

В связи с этим каждому начинающему следователю, окончившему высшее учебное заведение мы должны обеспечить такое вхождение в должность, которое позволит ему психологически и профессионально успешно начать работать, постепенно привыкнуть к нагрузкам при неукоснительном собцюдении служебной дисциплины, Присяги и Кодекса этики и служебного поведения.

Главную ответственность за это мы возможили на непосредственных руководителей, которые, к сожалению, зачастую самоустраняются от работы с молодежью. Есть примеры, когда руководители, погрузившись в служебную деятельность, не находят времени для персональньх бесед с молодыми сотрудниками, устраняются от проведения с ними индивидуальной работы.

Вместе с тем организация деятельности подчиненных имеет и социально-психологический аспект. Дружеские и доброжелательные отношения с комлегами, стремление оказать им демовую помощь, дать хороший совет повышают работоспособность всего комлектива.

Дия этого в 2016 году нами бым образован «Совет молодых следоватемей Следственного комитета Российской Федерации" (приказ СК России от 23.08.2016 № 88), который позволяет нам получать непосредственно от момодых специалистов информацию о тех проблемах, которые возникают в связи с их первыми шагами в профессии следователя.

Эти сведения в настоящее время аккумулируются в Управлении учебной и воспитательной работы, которым принимаются меры по созданию для следователей благоприятных условий дмя работы, в числе которых своевременное предоставмение отпусков*.

Отмечу также, что в апреле 2016 года Председателем СК РФ был образован Совет руководителей следственных органов Следственного комитета, которому поставцена задача систематически оказывать содействие в повышении квалификации сотрудникам, состоящим в резерве на выдвижение, обучать их успешному освоению обязанностей по вышестоящей должности по индивидуальным планам.

Несколько слов о критериях оценки нашей работы. Считаю, что сегодня в качестве основного критерия оценки работы руководителей следственных органов должен быть такой показатель, как общественное мнение, основанное на уверенности каждого гражданина в своей безопасности. Дия этого повседневная связь с населением помимо освещения нашей деятельности в средствах массовой информации, работы Общественных приемных Председателя Следственного комитета Российской Федерации и работы интернет-приемных следственных органов, должна обеспечиваться мичным участием каждого руководителя следственных органов в рассмот-

* Справка: Анализ эффективности исполнения графика отпусков показал многочисленные факты непредоставления отпусков сотрудникам на протяжении 2-х мет и бомее, а также большие задомженности по отпускам в ГСУ СК России по Красноярскому краю, г. Москве, в Волгоградской, Тамбовской, Тверской областях, а также ряде других следственных органах. С целью предотвращения подобных нарушений трудового законодательства управлением кадров специально подготовлено информационное письмо. 
рении обращений граждан, их тщательном анализе и устранении имеющихся недостатков в работе. И что немаловажно - дия решения многих кАючевых вопросов по противодействию преступности и выработки оптимальных управленческих решений необходимо активнее использовать потенциал общественных советов при следственных органах, а также волонтерские объединения, которые оказывают нам немалую помощь в розыске пропавших несовершеннолетних.

***

Особое значение Следственный комитет придаёт расследованию коррупционных преступлений. Актуальность этой работы вытекает из недавно принятого Указа Президента Российской Федерации от 16.08.2021 № 478 «О Национальном плане противодействия коррупции на 2021 - 2024 годы». Следственному комитету Российской Федерации предписано обеспечить в соответствии с Национальным планом реализацию предусмотренных им мероприятий и внесение изменений в свои планы противодействия коррупции.

Дия этого созданы специализированные подразделения, как по расследованию, так и по процессуальному контролю по уголовным делам

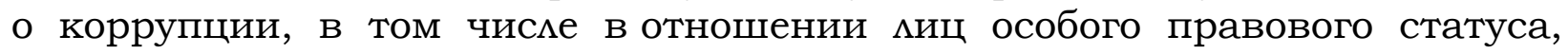
и о наиболее сложных - налоговых преступлениях.

ДАя повышения эффективности такой работы заключены соглашения со Счетной палатой Российской Федерации, Федеральной налоговой службой, Росфинмониторингом. Созданы межведомственные рабочие группы, проведены совместные заседания комлегий. Этот комплекс организационно-управленческих мер позволяет значительно результативнее пресекать хищения финансовых средств страны, направленных на обеспечение социальных программ и на укрепление обороноспособности нашей страны.

В целом если привести наши показатели на этом направлении деятельности, то с 2011 года следователями Следственного комитета проверены свыше 220 тыс. сообщений о коррупционных преступлениях, возбуждено более 130 тысяч уголовных дел. В суд направлено свыше 55 тысяч уголовных дел. Пресечена деятельность почти трехсот организованных преступных групп и 19 преступных сообществ, совершивших коррупционные преступления.

С 2011 по 2016 год в качестве обвиняемых по направленным в суд угомовным делам о преступлениях коррупционной направленности следователями Следственного комитета привлечено 3666 миц, обладающих, согласно главе 52 Уголовно-процессуального кодекса, особым правовым статусом. В их числе 1185 глав муниципальных образований органов местного самоуправмения, 1233 депутата местных органов власти, 433 следователя и руководителя следственных органов, 319 адвокатов, 88 прокуроров, 68 депутатов законодательных органов субъектов Российской Федерации, 25 судей.

По уголовным делам о коррупционных преступлениях государству возмещено 24 мимлиарда 573 мимлиона рублей, и, кроме того, на сумму почти 30 мимлиардов рублей наложен арест на имущество обвиняемых.

В 2016 году к мишению свободы за коррупционные преступления осуждены бывший заместитель губернатора Томской области и глава Первомайского района Томской области; заместитель губернатора Новгород- 
ской области; бывшие мэры гг. Ярославмя и Благовещенска; бывший глава г. Покрова Владимирской области. В феврале 2017 г. вынесен обвинительный приговор бывшему заместителю председателя Ивановской городской думы, который требовал от предпринимателей денежные средства за выдемение в аренду земельных участков, необходимых для осуществления коммерческой деятемьности.

На раскрытии подобных коррупционных преступлений необходимо сосредоточиться и впредь. Для этого руководителям следственных управмений необходимо повседневно на демовой основе выстраивать взаимодействие с органами, осуществляющими оперативно-розыскную деятельность и добиваться весомых результатов.

Последовательно повышался объем возмещения причиненного преступлениями ущерба.

Так, в ходе предварительного следствия в 2016 году возмещено 45 мимлиардов рублей (2015 г. - 27). На сумму более 38 мимлиардов рублей наложен арест на имущество подозреваемых и обвиняемых в совершении преступлений, что на 94\% больше, чем в 2015 году (2015 г. - 19).

Вместе с тем 2 марта 2017 года на расширенном заседании комлегии Следственного комитета Российской Федерации Председателем СК РФ поставцена задача о проработке в тесном взаимодействии с МВД и ФСБ России, со Счетной палатой, Росфинмониторингом и органами прокуратуры дополнительных мер по обеспечению неотвратимости имущественной ответственности коррупционеров.

По окончании судебного рассмотрения дем о коррупции руководители следственных органов в системе служебной подготовки должны проводить тщательный разбор процесса расследования с учетом пробелов и недостатков, которые были выявлены в ходе судебного разбирательства.

Следует также отметить, что Следственный комитет предмагает вернуться к обсуждению вопроса о введении конфискации как меры уголовного наказания. Полагаю, что именно такая мера будет способствовать повышению превентивной функции уголовного закона, так как исключив из Уголовного кодекса такой эффективный инструмент, законодатель не предложил адекватной его замены.

Кроме того, следует сказать и о том, что действующее уголовное законодательство допускает изъятие имущества, переданного обвиняемым

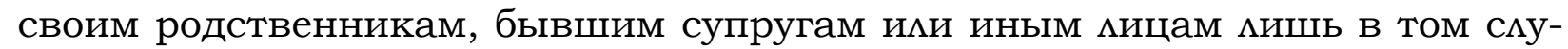
чае, когда эти мица знали о его преступном происхождении. Чтобы устранить этот пробел в законе необходимо предусмотреть возможность конфискации и в тех случаях, когда будет установцено, что имущество передано безвозмездно, вне зависимости от осведомленности о действительном источнике его происхождения.

Следует подчеркнуть, что непременным оружием следователя по демам о коррупционных преступцениях домжна быть их действенная профимактика.

В 2016 году по 95\% уголовных дем следователями внесены представ-

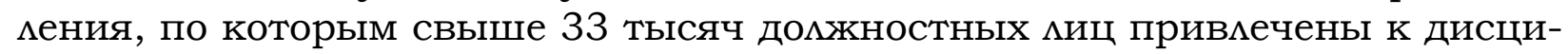
плинарной ответственности, что на 4\% больше, чем в 2015 году. 
В настоящее время, как вы знаете, формирование единой государственной системы профилактики преступлений и иных правонарушений занимает одно из ключевых мест в числе национальных приоритетов современной России. Поэтому по каждому из вносимых следователями Следственного комитета представцений по демам о коррупции необходимо добиваться реального устранения обстоятельств, которые выявлены в ходе расследования и способствовали коррупции.

$* * *$

Одним из приоритетных направцений нашей деятельности является раскрытие и расследование преступлений прошиых мет. На это направлены усилия не только следователей, но и оперативных сотрудников органов внутренних дем.

Важность нашей совместной работы заключается в том, чтобы каждое преступление было раскрыто, а преступник понес заслуженное наказание. Раскрытие мюбого преступления - это всегда результат комлективного труда. Большое значение при этом имеет оперативно-розыскное сопровождение следственных действий, умелое использование агентурного аппарата, своевременное применение всех существующих экспертных возможностей.

Если не удалось предотвратить преступление, мы обязаны обеспечить уголовное преследование виновного, сколько бы мет не минуло со дня трагедии. Подробная информация о раскрытии таких преступлений, как вы знаете, публикуется в специальном разделе "Преступления прошлых мет" на сайте Следственного комитета РФ.

Результаты нашей деятельности в этом направцении внушают определенный оптимизм. С 2011 года по настоящее время следователями Следственного комитета РФ совместно с оперативными подразделениями МВД России и ФСБ России раскрыты почти 42 тысячи преступлений, уголовные дела по которым были приостановлены в прошлые годы. В их числе 3774 убийств, 1947 фактов умышленного причинения тяжкого вреда здоровью, повлекшего по неосторожности смерть потерпевшего, а также 2194 изнасимований и насимьственных действий сексуального характера.

Данные показатели стали возможными вследствие развития изначально внедренной нами новой организационной формы раскрытия преступлений прошлых мет. Это аналитические группы, созданные в каждом следственном управлении Следственного комитета РФ. Их задачами явцяются планомерное изучение уголовных дел о нераскрытых преступлениях прошлых мет, принятие мер к отмене необоснованных процессуальных решений, участие в сопровождении дополнительного расследования.

Но прежде всего в организации деятельности таких групп важен сам подход к работе, который должен быть добросовестным, методичным и системным. Ведь своевременное неустановцение и непривцечение к угомовной ответственности виновных порождает у них чувство безнаказанности и, как следствие, совершение ими новых, более изощренных преступцений. 
$* * *$

Под особым контролем находится раскрытие преступлений, вызвавших широкий общественный резонанс.

K примеру, оперативно были раскрыты: в г. Москве - убийство малометней Мещеряковой; в Красноярском крае-убийство семьи Савченко; в Иркутской области - убийство семьи Черниговых и разбойное нападение на ветерана Великой Отечественной войны Киримьчик; в Самарской области - убийство Павловой и её несовершеннолетнего сына, убийство семьи Гошта, убийство Вашуркиной и покушение на убийство её супруга; в Кемеровской области - убийство малолетней Вечкановой; в Челябинской области - убийство несовершеннолетней Поповой; в Республике Хакасия - убийство малометней Байкаловой и многие другие резонансные преступления.

Большинство таких преступлений раскрывается при активном применении криминалистической техники, благодаря которой выявцяются также серийные тяжкие преступления против мичности.

Об этом, например, свидетельствуют раскрытые преступления, совершенные жителем Пермского края, задержанного за похищение 17 января 2017 года 12-летней девочки в г. Оренбурге. После задержания подозреваемого удалось установить совпадение генотипа задержанного с генотипом мица, совершившего убийства нескольких несовершеннолетних в Пермском крае в $2011-2013$ гг.

В 2015 году в Ивановской области следователями Следственного комитета совместно с оперативными подразделениями МВД России пресечена деятельность серийного преступника, совершившего 119 преступлений против половой неприкосновенности несовершеннолетних (приговором суда ему назначено наказание в виде 19 мет мишения свободы).

В Камчатском крае за совершение аналогичных преступлений в отношении шести школьниц изобличен и осужден педофим к 23 годам мишения свободы.

Кроме того, при непосредственном участии сотрудников ГАавного управления криминалистики при проверке миц, проводивших сантехнические, сварочные и иные работы в домах г. Междуреченска (Кемеровская область), расположенных в районе совершенного в 2007 году убийства несовершеннолетней Бахтуровой, установмен $\Lambda$., который бым дактилоскопирован и проверен по базе АДИС "Папимон". Отпечаток пальца руки $\Lambda$. совпал со следом, оставленным на менте скотч, которым была связана потерпевшая, а выводы молекулярно-генетической экспертизы подтвердими совпадение ДНК-профиля $\Lambda$. с ДНК-профилем биологических следов, оставменных при контакте с Бахтуровой. Убийца, скрывавшийся от правосудия почти 10 мет, был изобцичен.

Расследование таких преступлений, по сути, это криминалистическая деятельность. Насколько эффективно следователь применяет на практике криминалистическую технику и рекомендации науки криминалистики, зависит успех расследования в целом.

На практике недостатки в использовании технических средств наиболее часто связаны с тем, что следователи порой имеют невысокий уро- 
вень знаний, умений и навыков по их применению. Поэтому в быстро меняющейся из-за новых криминальных вызовов и угроз оперативной обстановке, в связи с повышением общественной опасности современной преступности на первый план выдвигается тщательная подготовка высокопрофессиональных сотрудников, способных использовать передовые достижения криминалистики. Однако сегодня во многом существует разрыв между наукой, теорией и следственной практикой.

Наша цель - выработать наиболее оптимальные пути преодоления этого разрыва, обеспечив решение триединой задачи: приведение науки в соответствие с реалиями современности, обеспечение качества и глубины теоретической подготовки и, самое гмавное, адаптацию практики к современным криминальным вызовам и угрозам.

Задача руководителей следственных органов заключается в том, чтобы обеспечить необходимую профессиональную подготовку своих подчиненных. При этом готовность следователей надлежащим образом применять в процессе расследования современные научно-технические средства должна обеспечиваться следующими составляющими деятельности руководителей следственного органа:

наделением следователей необходимым и достаточным количеством криминалистической техники;

ведением надлежащего учета и контроля за хранением, использованием, ремонтом и пополняемостью научно-технических средств;

знанием следователями возможностей, правиц и приемов использования научно-технических средств и их умением мично применять технические средства при производстве следственных действий.

В домжностные обязанности одного из следователей (Аибо иного должностного мица следственного органа) домжны входить: учет и контроль за состоянием криминалистической техники; её распределение между следователями; обеспечение необходимым комплектом научно-технических средств дежурного следователя; своевременное попоцнение и ремонт криминалистической техники.

Кроме того, в следственном органе должно быть организовано постоянное обучение следователей, в том числе с привлечением соответствующих специалистов (следователи-криминалисты, сотрудники экспертнокриминалистических подраздемений органов внутренних дец). Это особенно важно для тех следственных органов, где для участия в следственных действиях не всегда имеется возможность привлечения сотрудников экс-

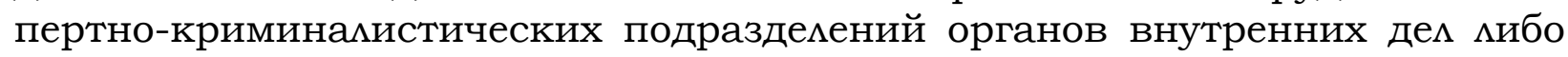
следователей-криминалистов.

Если же работа по применению научно-технических средств поруча-

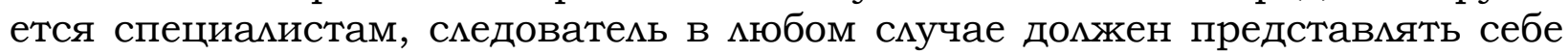
возможности используемых средств, чтобы руководить их работой. А руководитель следственного органа должен нацеливать подчиненных работников и обеспечивать им использование в уголовном процессе вещественных доказательств, заключений экспертов как важнейших объективных источников создания надежной доказательственной базы. 
$* * *$

На сегодняшний день созданы все условия дмя дальнейшего повышения качества работы следователей-криминалистов. Их полномочия закреплены в уголовно-процессуальном законе, отражены в Федеральном законе "О Следственном комитете Российской Федерации". Издан ведомственный приказ, детально регламентирующий компетенцию следоватемей-криминалистов.

ГАавной задачей следователей-криминалистов является криминалистическое сопровождение расследования по уголовным делам, составляющей частью которого явмяется применение при производстве следственных действий криминалистической и специальной техники. Речь идет об оказании практической помощи в раскрытии и расследовании тяжких и особо тяжких преступлений с выездом на места происшествий.

При этом на следователей-криминалистов возможены задачи по внедрению в следственную практику технико-криминалистических средств, применению при производстве следственных действий современной и высокотехнологичной криминалистической и специальной техники, в том числе с целью отыскания орудий, следов преступления и других вещественных доказательств.

Одним из основных направлений работы криминалистов, как уже было отмечено, является аналитическая работа, в частности, анализ состояния и динамики преступности, что позволяет получить систематизированные сведения о мотивах преступной деятельности в тот или иной период или на той ими иной территории, способах совершения преступлений, периодах времени совершения, а также орудиях преступцения.

Следует подчеркнуть, что криминалисты центрального аппарата СК РФ хорошо проявили себя при расследовании сложных неочевидных преступцений, происшествий и катастроф, повлекших массовую гибель

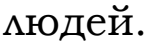

Так, сотрудники ГАавного управления криминалистики непосредственно участвовали в производстве первоначального комплекса следственных действий по наиболее резонансным уголовным демам по фактам: крушения воздушного судна, следовавшего из Египта в г. Санкт-Петербург; схода четырех вагонов пассажирского поезда сообщением Екатеринбург Адмер; крушения в Охотском море траулера "Дальний Восток"; гибели мюдей и массового уничтожения имущества в результате произошедших пожаров в Республике Хакасия; крушений над Истринским водохранилищем вертолета и гидроплана; пожара в психоневрологическом диспансере и гибели 23 человек в Воронежской области и многих других.

Следователями-криминалистами Следственного комитета РФ проводится большая работа по раскрытию преступцений в отношении несовершеннолетних.

Во взаимодействии с оперативными подразделениями МВД России и общественностью раскрыт, помимо вышеприведенных в качестве примеров преступлений, целый ряд других резонансных общественно опасных деяний, в том числе убийства малолетних - Прокопенко (Ставропольский край), Бабуркевич (Забайкальский край), Шкапцовой (Брянская область), 
Рудаковой (Ростовская область), а также множество преступлений сексуального характера в отношении несовершеннолетних в Иркутской, Московской, Тульской областях и других регионах.

Опыт расследования подобных сложных преступцений молодые следователи обязаны всегда держать "под рукой".

Арсенал криминалистических подразделений Следственного комитета РФ пополнен высокотехнологичным оборудованием как отечественного, так и зарубежного производства, в том числе:

мобильными комплексами по сбору и анализу цифровых данных "UFED», позволяющими считывать информацию из мобильных устройств, а также восстанавливать удаленные пользователем файлы;

цианакрилатными камерами "MISONIX CA-3000", предназначенными для выявления следов пальцев рук; фотокомплектами 3D панорамной съемки "Canon";

обеспечивающими эффект реального присутствия участников угомовного процесса; оптическими устройствами по выявлению скрытых видеокамер «Оптик-2»;

портативными высокоинтенсивными источниками криминалистического света "Projektina SL-450", "ИКС-450, "МИКС-450".

С учетом криминогенной обстановки, географического положения и ряда других факторов, отдемьные подраздемения криминалистики следственных органов по субъектам Российской Федерации имеют также на оснащении:

георадары (30), предназначенные дмя дистанционного обнаружения различных метамлических и неметамлических объектов в различных средах; эхомоты (51), предназначенные дия обнаружения подводных объектов;

тепловизоры (26), основной задачей которых является обнаружение теплоконтрастных объектов;

нелинейные мокаторы (51), обеспечивающие поиск электронных устройств (мобильных и других);

портативные анализаторы паров взрывчатых веществ (17), предназначенные для поиска взрывчатых веществ, следов их хранения или ношения;

пневмомодуми (46) с полной системой жизнеобеспечения, предназначенные для работы на удаленных территориях при расследовании техногенных катастроф и крупных аварий, а также иное оборудование.

Это позволяет решать весь спектр задач, стоящих перед следственными органами Следственного комитета Российской Федерации.

Что же касается методического обеспечения, то только в 2016 году были подготовлены методические рекомендации:

«Расследование преступлений против половой свободы и половой неприкосновенности несовершеннолетних, совершенных с использованием сети Интернет»;

"Особенности проведения доследственных проверок, расследования уголовных дел по фактам самоубийств и попыток самоубийств несовершеннолетних"; 
«Порядок проведения судебно-медицинской экспертизы и установления причинно-следственных связей по фактам неоказания или ненадлежащего оказания медицинской помощи при расследовании ятрогенных преступлений»;

«О повышении эффективности использования в раскрытии и расследовании преступлений экспертно-криминалистических учетов".

Следует также отметить, что активно осуществляется деятельность учебных кабинетов криминалистики следственных органов, в которых свой уровень своей профессиональной подготовки повысило значитецьное число следователей, следователей-криминалистов и руководителей следственных подраздемений.

Дия обучения следователей в учебных кабинетах, помимо прочего, применяются программы “Виртуальный осмотр места происшествия: учебно-методический комплекс" (который имеется во всех следственных органах), "Виртуальный обыск (выемка): учебно-методический комплекс".

Использование указанных программ наглядно демонстрирует уже имеющиеся навыки сотрудников следственных органов при проведении указанных следственных действий и помогает устранить недостатки.

В помощь начинающим следователям создаются учебные видеофимьмы.

Помимо этого, ГАавным управлением криминалистики разработана и направлена для внедрения в следственные органы типовая программа стажировки следователей: "Осмотр места происшествия: работа со следами, процессуальное оформхение». Данная программа предназначена дмя повышения уровня знаний сотрудников, имеющих стаж работы до одного года. Обучение предполагает усвоение следователем особенностей тактики осмотра места происшествия по размичным категориям и способам совершения преступлений, получение навыков работы с техническими средствами дия выявления, фиксации и изъятия следов, умение построения версий, а также грамотное процессуальное оформление следственных действий.

$* * *$

Затрону ещё один крайне важный для всего общества вопрос - защита прав несовершеннолетних.

В 2016 году следователями Следственного комитета расследовано почти 19 тысяч преступлений, жертвами которых стали дети, из них 464 убийства и более 6 тыс. изнасилований и фактов насильственных действий сексуального характера.

Особо остро в истекшем году встала проблема детских суицидов, в результате которых погибло 720 подростков.

Наибольшую опасность, как вы знаете, сегодня представляют дейст-

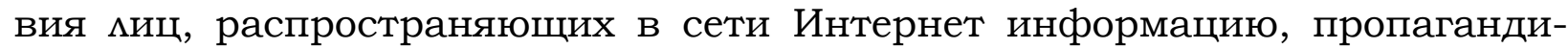
рующую тематику суицида, популяризирующую эстетику смерти и призывающую несовершеннолетних совершать самоубийства.

Следственным комитетом РФ предъявлено обвинение администратору одной из так называемых "групп смерти", зарегистрированному под 
сетевым именем "Фимипп $\Lambda$ им. В настоящее время он находится под стражей.

В то же время большинству таких, как он, удаётся уйти от ответственности, поскольку совершаемые ими действия не всегда охватываются объективной стороной преступления, предусмотренного статьей 110 Угомовного кодекса РФ (Доведение до самоубийства).

Помагаю, что дия эффективного предотвращения подобных преступлений следует ввести уголовную ответственность за склонение к совершению самоубийства, в частности, путем распространения соответствующей информации с использованием электронных или информационно-телекоммуникационных сетей, в том числе сети Интернет.

Благодаря активной позиции заместителя Председателя Государственной Думы Ирины Анатольевны Яровой предложения Следственного комитета нашии поддержку на площадке межведомственной рабочей группы, которой разработан соответствующий проект федерального закона. Все правоохранительные и другие государственные органы выступили в этом вопросе единым фронтом, поддержав такую инициативу.

Следственным комитетом 22 февраля 2017 года согласован официальный отзыв Правительства Российской Федерации, которым указанный проект федерального закона поддержан.

Кроме того, по решению Совета Государственной Думы создана пармаментская группа по подготовке комплексного проекта федерального закона, направленного на усицение мер защиты детей от сексуального насимия, в работе которой мы также принимаем активное участие. Нами представлены предцожения о неприменении сроков давности к преступлениям против половой неприкосновенности несовершеннолетних, а также об установцении уголовной ответственности за укрывательство совершенных в отношении детей преступлений средней тяжести и тяжких.

$* * *$

В нашей многонациональной и многоконфессиональной стране в обязательном порядке следует системно подходить к разработке мер по противодействию экстремизму и терроризму.

Как вы знаете, принят закон о бцокировке экстремистских сайтов (Федеральный закон от 28.12.2013 № 398-Ф3 “О внесении изменений в Федеральный закон "Об информации, информационных технологиях и о защите информации"), а в ноябре 2014 года Президентом Российской Федерации утверждена Стратегия противодействия экстремизму в Российской Федерации.

Это позволяет Следственному комитету Российской Федерациисовместно с другими государственными органами, прежде всего с Федеральной службой по надзору в сфере связи, информационных технологий и массовых коммуникаций (Роскомнадзор), Генеральной прокуратурой РФ и Министерством юстиции РФ оперативно реагировать на провокации экстремистов, использующих интернет-ресурсы для разжигания национальной и ремигиозной вражды. Позволяет удалять информацию, содержащую призывы к массовым беспорядкам, осуществлению экстремистской деятельности, 
участию в массовых (публичных) мероприятиях, проводимых с нарушением установценного порядка.

Несмотря на это ситуация в области противодействия экстремизму и терроризму в России всё ещё остаётся сложной - число экстремистских преступлений в 2016 году увеличилось на 11\% (1 161 преступление).

Следователями Следственного комитета возбуждено 882 уголовных дема о преступлениях экстремистской направленности и 283 дема о преступлениях террористического характера. В суд направлены 522 уголовных дема об экстремизме и 98 - о терроризме.

Сложная оперативная обстановка требует координации усиций всех противодействующих экстремизму и терроризму структур, ужесточения контроля миграционных потоков, пресечения вербовочной деятельности со стороны международных террористических организаций, миквидации ресурсного и финансового обеспечения бандитских групп.

Учитывая имеющиеся факты выезда из России в "горячие точки" радикально настроенных миц, в первую очередь из числа молодёжи дмя участия в военных действия на стороне боевиков, следует усимить антиэкстремистскую работу с участием представителей территориальных подраздемений Министерства образования и науки, органов внутренних дел, Роскомнадзора, Росмолодежи и Роспечати. Надо шире привлекать общественность и средства массовой информации, молодёжные и студенческие организации, волонтёров, преподавательский состав вузов, а в наиболее проблемных регионах - инициировать профилактическую работу на уровне школ.

Дмя цитирования: Бастрыкин А.И. Вопросы повышения эффективности организации работы следственных органов Следственного комитета Российской Федерации: мекция // Юридическая мысль. - 2021. - № 3 (123). - С. 99-111.

DOI: $10.47905 /$ MATGIP.2021.123.3.005

\title{
Lecture: \\ "Issues of increasing the efficiency of organizing the work of investigative bodies of the Investigative Committee of the Russian Federation"
}

\begin{abstract}
Alexander I. Bastrykin*
Annotation. This lecture contains proposals for improving the efficiency of organizing the work of the investigative bodies of the Investigative Committee of the Russian Federation at the present stage. The author notes that at all times the successful organization of the work of any body of state power, including the investigative bodies of the Investigative Committee, is possible only as a result of a systematic increase in the level of professional training, which is achieved through the use of various forms of training.

* Bastrykin Alexander Ivanovich, Chairman of the Investigative Committee of the Russian Federation, Doctor of Law, Professor, Honored Lawyer of the Russian Federation. E-mail: lawinst-spb@mail.ru
\end{abstract}


The author believes that a novice investigator who graduated from a higher educational institution needs to ensure such entry into a position that will allow him to psychologically and professionally start working successfully, gradually get used to the loads with strict observance of official discipline, the Oath and the Code of Ethics and Service Conduct.

Key words: efficiency, criminal legislation, criminal procedure law, Investigative Committee, prosecutor's office, professional training and retraining.

The successful organization of the work of the investigative bodies of the Investigative Committee is possible only as a result of a systematic increase in the level of professional training of investigators, which is achieved through the use of various forms of training.

Investigators need to constantly take care of the rational, economical organization of their work, not to allow unreasonable distraction from the performance of their official duties. The most important condition for improving the activities of investigators is the study and practical application of scientific recommendations and best practices in conducting an investigation.

Each employee of the investigative bodies is obliged to possess scientific recommendations, advanced techniques and methods of work, for which it is necessary to constantly study information letters, reviews, periodicals of the Investigative Committee and other educational and methodological literature, to introduce the experience described in them into their own practice.

It is known that the most important elements of organizing investigative work are well-thought-out work planning and well-defined control. The absence of a plan causes unjustified losses of working time, distracts investigators from performing their direct duties, and lack of control often gives rise to irresponsibility and leads to an extension of the deadline and a delay in the investigation.

In this regard, the day-to-day work of an investigator should be structured systematically and be aimed at reducing the time frame for criminal proceedings, improving the quality of the investigation, and ensuring effective procedural control to protect the rights and legitimate interests of citizens. Otherwise, the unjustifiably long terms of the investigation (as well as the long terms for the execution of court decisions) will become the reason for the claim for compensation for violation of the right to legal proceedings within a reasonable time.

Regarding this issue, it should be noted that decisions on the initiation of petitions for the extension of procedural time limits in many cases are made "according to a template". The argument about the need to carry out a large number of investigative actions is often used in them as a cliche, as well as a reference to the fact that the case is of particular complexity. The investigators' decisions do not provide a full explanation of the circumstances that served as the basis for filing applications for the extension of procedural time limits.

Often there is no clear plan of action that should be carried out during the requested procedural period, including with the participation of operational units. All this is one of the reasons that, despite our increased requirements for departmental procedural control, the number of criminal cases investigated in more than two months in 2016 practically remained at the level of $2015-43$ 505 cases $(11$ months $2015-43496)$. The number of criminal cases re-turned by the prosecutor for additional investigation has increased by $6.5 \%$ 
$(3,213,11$ months of $2015-3,016)$. And this despite the fact that the reduction of procedural terms and improvement of the quality of the investigation are constantly in the field of vision of the prosecutor's office, which more and more fundamentally supervise these indicators of investigative work.

I emphasize that the guarantee of the effectiveness of procedural control is not in the number of controllers and not in the desire to cover the entire scope of the investigator's procedural activities, but in the creation of his wellthought-out system, the construction and proper organization of which should be given increased attention.

The most important issue of organizing the work of investigative bodies is the reinforcement of young specialists and the adaptation of graduates of law schools. Almost $60 \%$ of our investigators have up to 5 years of work experience.

We have been working with such young cadres for the seventh year already, and during this time the investigators of the Investigative Committee have checked over 5 million reports of a crime, and 808 thousand criminal cases have been initiated. More than 570 thousand criminal cases (572 299) were sent to the court against 640 thousand accused.

In this regard, for each novice investigator who graduated from a higher educational institution, we must ensure such entry into a position that will allow him to start working psychologically and professionally, gradually get used to the loads with strict observance of official discipline, the Oath and the Code of Ethics and Service Conduct.

We have assigned the main responsibility for this to our immediate managers, who, unfortunately, often withdraw themselves from work with young people. There are examples when managers, immersed in official activities, do not find time for personal conversations with young employees, and are avoided from conducting individual work with them.

At the same time, the organization of the activities of subordinates also has a socio-psychological aspect. Friendly and benevolent relations with colleagues, the desire to provide them with business assistance, to give good advice increase the efficiency of the entire team.

For this, in 2016 we formed the Council of Young Investigators of the Investigative Committee of the Russian Federation (order of the Investigative Committee of Russia dated 23.08.2016 No. 88), which allows us to receive information directly from young specialists about the problems that arise in connection with their first steps in the profession of an investigator.

This information is currently being accumulated in the Office of Educational and Educational Work, which is taking measures to create favorable conditions for investigators for work, including the timely provision of leaves*.

I would also like to note that in April 2016, the Chairman of the Investigative Committee of the Russian Federation formed the Council of Heads of In-

* Reference: Analysis of the effectiveness of the implementation of the vacation schedule showed numerous facts of non-provision of vacations to employees for 2 years or more, as well as large vacation debts in the Main Investigative Directorate of the Investigative Committee of Russia in the Krasnoyarsk Territory, Moscow, in the Volgograd, Tambov, Tver regions, as well as a number of other investigating authorities. In order to prevent such violations of labor legislation, the personnel department has specially prepared an information letter. 
vestigative Bodies of the Investigative Committee, which was tasked with systematically providing assistance in improving the qualifications of employees in the reserve for nomination, teaching them how to successfully master the duties of a higher positions according to individual plans.

A few words about the criteria for evaluating our work. I believe that today, as the main criterion for assessing the work of the heads of investigative bodies, there should be such an indicator as public opinion, based on the confidence of every citizen in his safety. For this, everyday communication with the population, in addition to covering our activities in the media, the work of the Public Receptions of the Chairman of the Investigative Committee of the Russian Federation and the work of the Internet reception of investigative bodies, should be ensured by the personal participation of each head of the investigative bodies in the consideration of citizens' appeals, their careful analysis and elimination of existing shortcomings in the work. And what is important - in order to solve many key issues in combating crime and to develop optimal management decisions, it is necessary to more actively use the potential of public councils at investigative bodies, as well as volunteer associations that provide us with considerable assistance in the search for missing minors.

The Investigative Committee attaches particular importance to the investigation of corruption crimes. The relevance of this work stems from the recently adopted Decree of the President of the Russian Federation of August 16, 2021 No. 478 "On the National Anti-Corruption Plan for 2021 - 2024". The Investigative Committee of the Russian Federation was instructed to ensure, in accordance with the National Plan, the implementation of the measures envisaged by it and amendments to its anti-corruption plans.

For this, specialized units have been created, both for investigation and for procedural control in criminal cases of corruption, including in relation to persons of special legal status, and the most complex ones - tax crimes.

To improve the efficiency of this work, agreements have been concluded with the Accounts Chamber of the Russian Federation, the Federal Tax Service, and Rosfinmonitoring. Interdepartmental working groups have been created, joint meetings of the collegiums have been held. This complex of organizational and managerial measures makes it possible to stop the embezzlement of the country's financial resources, aimed at providing social programs and strengthening the defense capability of our country, much more effectively.

In general, if we cite our indicators in this area of activity, then since 2011, investigators of the Investigative Committee have checked over 220 thousand reports on corruption crimes, initiated more than 130 thousand criminal cases. Over 55 thousand criminal cases were sent to the court. The activities of almost three hundred organized criminal groups and 19 criminal communities that committed corruption crimes were suppressed.

From 2011 to 2016, the investigators of the Investigative Committee attracted 3,666 persons who, according to Chapter 52 of the Criminal Procedure Code, have a special legal status, as defendants in criminal cases of corruption-related crimes sent to the court. Among them are 1,185 heads of munici- 
palities of local self-government bodies, 1,233 deputies of local authorities, 433 investigators and heads of investigative bodies, 319 lawyers, 88 prosecutors, 68 deputies of legislative bodies of the constituent entities of the Russian Federation, 25 judges.

In criminal cases of corruption crimes, the state has been reimbursed 24 billion 573 million rubles, and, in addition, the property of the accused has been seized in the amount of almost 30 billion rubles.

In 2016, the former deputy governor of the Tomsk region and the head of the Pervomayskiy district of the Tomsk region were sentenced to imprisonment for corruption crimes; Deputy Governor of the Novgorod Region; former mayors Yaroslavl and Blagoveshchensk; former head of the city of Pokrov, Vladimir region. In February 2017, a guilty verdict was passed on the former deputy chairman of the Ivanovo City Duma, who demanded money from entrepreneurs for the lease of land plots necessary for commercial activities.

It is necessary to focus on solving such corruption crimes in the future. For this, the heads of the investigative departments need to build up interaction with the bodies carrying out operational-search activities on a business basis on a day-to-day basis and achieve significant results.

The volume of compensation for damage caused by crimes has consistently increased.

So, during the preliminary investigation in 2016, 45 billion rubles were reimbursed $(2015-27)$. For the amount of more than 38 billion rubles, the property of suspects and accused of committing crimes was seized, which is 94\% more than in 2015 (2015 - 19).

At the same time, on March 2, 2017, at an expanded meeting of the board of the Investigative Committee of the Russian Federation, the Chairman of the RF IC was set the task of working out, in close cooperation with the Ministry of Internal Affairs and the FSB of Russia, with the Accounts Chamber, Rosfinmonitoring and the prosecution authorities, additional measures to ensure the inevitability of property from -responsibility of corrupt officials.

At the end of the judicial review of corruption cases, the investigative officers in the training system should conduct a thorough review of the investigation process, taking into account the gaps and shortcomings that have been identified during the trial.

It should also be noted that the Investigative Committee proposes to return to the discussion of the issue of introducing confiscation as a measure of criminal punishment. I believe that just such a measure will help to enhance the preventive function of the criminal law, since having excluded such an effective instrument from the Criminal Code, the legislator did not offer an adequate replacement.

In addition, it should be said that the current criminal legislation allows the seizure of property transferred to the accused to their relatives, exspouses or other persons only if these persons knew about its criminal origin. To eliminate this gap in the law, it is necessary to provide for the possibility of confiscation in those cases when it is established that the property was transferred free of charge, regardless of the knowledge of the actual source of its origin. 
It should be emphasized that an indispensable weapon of an investigator in cases of corruption crimes should be their effective prevention.

In 2016 , in $95 \%$ of criminal cases, investigators made submissions, for which more than 33 thousand officials were brought to disciplinary responsibility, which is $4 \%$ more than in 2015 .

Currently, as you know, the formation of a unified state system for the prevention of crimes and other offenses is one of the key places among the national priorities of modern Russia. Therefore, for each of the representations made by the investigators of the Investigative Committee on corruption cases, it is necessary to achieve a real elimination of the circumstances that were revealed during the investigation and contributed to corruption.

One of the priority areas of our activity is the disclosure and investigation of past crimes. The efforts of not only investigators, but also operational officers of the internal affairs bodies are aimed at this.

The importance of our joint work lies in the fact that each crime is solved, and the offender is punished. The disclosure of any crime is always the result of collective labor. At the same time, operational-search support of investigative actions, skillful use of the agent apparatus, and the timely use of all existing expert capabilities are of great importance.

If we failed to prevent the crime, we are obliged to ensure the criminal prosecution of the perpetrator, no matter how many years have passed since the day of the tragedy. Detailed information on the disclosure of such crimes, as you know, is published in a special section "Crimes of the past years" on the website of the Investigative Committee of the Russian Federation.

The results of our activities in this direction inspire a certain optimism. From 2011 to the present, investigators of the Investigative Committee of the Russian Federation, together with the operational units of the Ministry of Internal Affairs of Russia and the FSB of Russia, have solved almost 42 thousand crimes, criminal cases on which were suspended in previous years. Among them there are 3,774 murders, 1,947 facts of deliberate infliction of grievous bodily harm, which inadvertently entailed the death of the victim, as well as 2,194 rapes and violent acts of a sexual nature.

These indicators became possible due to the development of a new organizational form of disclosure of crimes of past years, originally introduced by us. These are analytical groups created in each investigation department of the Investigative Committee of the Russian Federation. Their tasks are the systematic study of criminal cases on unsolved crimes of past years, taking measures to cancel unfounded procedural decisions, participating in the support of additional investigations.

But above all, in organizing the activities of such groups, the very approach to work is important, which must be conscientious, methodical and systematic. After all, the timely failure to identify and prosecute the perpetrators gives them a sense of impunity and, as a result, their commission of new, more sophisticated crimes. 
$* * *$

Under special control is the disclosure of crimes that have caused a wide public response.

For example, the following were promptly disclosed: in Moscow - the murder of little-year-old Meshcheryakova; in the Krasnoyarsk Territory - the murder of the Savchenko family; in the Irkutsk region - the murder of the Chernigov family and a robbery on the veteran of the Great Patriotic War Kirilchik; in the Samara region - the murder of Pavlova and her minor son, the murder of the Goshta family, the murder of Vashurkina and the attempted murder of her husband; in the Kemerovo region - the murder of a minor Vechkanova; in the Chelyabinsk region - the murder of a minor Popova; in the Republic of Khakassia - the murder of young Baikalova and many other highprofile crimes.

Most of these crimes are solved with the active use of forensic techniques, thanks to which serial grave crimes against a person are also revealed.

This, for example, is evidenced by the solved crimes committed by a resident of the Perm Territory, detained for the abduction of a 12-year-old girl on January 17, 2017 in the city of Orenburg. After the arrest of the suspect, it was possible to establish the coincidence of the detainee's genotype with the genotype of the person who had committed the murders of several minors in the Perm Territory in 2011-2013.

In 2015, in the Ivanovo Region, investigators of the Investigative Committee, together with the operational units of the Ministry of Internal Affairs of Russia, suppressed the activities of a serial criminal who had committed 119 crimes against the sexual inviolability of minors (he was sentenced to 19 years in prison by a court verdict).

In the Kamchatka Territory, a pedophile was exposed and sentenced to 23 years in prison for committing similar crimes against six schoolgirls.

In addition, with the direct participation of employees of the Main Department of Criminalistics, when checking the persons who carried out plumbing, welding and other work in the houses of Mezhdurechensk (Kemerovo region), located in the area of the murder of the minor Bakhturova committed in 2007, L. fingerprinted and verified against the Papilon AFIS database. The fingerprint of L.'s hand coincided with the trace left on the tape with which the patient was tied, and the conclusions of the molecular genetic examination confirmed the coincidence of L.'s DNA profile with the DNA profile of biological traces left in contact with Bakhturova. The killer, who had been hiding from justice for almost 10 years, was exposed.

Investigation of such crimes is, in fact, a forensic activity. How effectively the investigator applies in practice the forensic techniques and recommendations of the science of forensic science, depends on the success of the investigation as a whole.

In practice, shortcomings in the use of technical means are most often associated with the fact that investigators sometimes have a low level of knowledge, skills and abilities in their application. Therefore, in the rapidly changing operational environment due to new criminal challenges and threats, in connection with the increased social danger of modern crime, the thorough train- 
ing of highly professional employees capable of using the advanced achievements of forensic science is highlighted. However, today there is a large gap between science, theory and investigative practice.

Our goal is to develop the most optimal ways to overcome this gap, ensuring the solution of the triune task: bringing science in line with the realities of our time, ensuring the quality and depth of theoretical training and, most importantly, adapting practice to modern criminal challenges and threats.

The task of the heads of investigative bodies is to provide the necessary professional training for their subordinates. At the same time, the readiness of investigators to properly apply modern scientific and technical means in the investigation process should be ensured by the following components of the activities of the heads of the investigative body:

endowing investigators with the necessary and sufficient amount of forensic technology;

maintaining proper accounting and control over the storage, use, repair and replenishment of scientific and technical means;

knowledge by investigators of the possibilities, rules and methods of using scientific and technical means and their ability to personally apply technical means in the production of investigative actions.

The duties of one of the investigators (or another official of the investigative body) should include: accounting and control over the state of forensic technology; its distribution among the investigators; provision of the necessary set of scientific and technical means for the investigator on duty; timely replenishment and repair of criminalistic equipment.

In addition, the investigative body should organize constant training of investigators, including with the involvement of relevant specialists (forensic investigators, employees of forensic departments of the internal affairs bodies). This is especially important for those investigative bodies where it is not always possible to involve employees of the forensic departments of the internal affairs bodies or forensic investigators to participate in investigative actions.

If the work on the use of scientific and technical means is entrusted to specialists, the investigator, in any case, must imagine the possibilities of the means used in order to direct their work. And the head of the investigative body must target subordinate workers and ensure that they use material evidence in the criminal process, expert opinions as the most important objective sources for creating a reliable evidence base.

To date, all conditions have been created for further improving the quality of the work of forensic investigators. Their powers are enshrined in the criminal procedure law, reflected in the Federal Law "On the Investigative Committee of the Russian Federation". A departmental order has been issued that regulates in detail the competence of forensic investigators.

The main task of forensic investigators is the forensic support of the investigation of criminal cases, a component of which is the use of forensic and special techniques in the conduct of investigative actions. We are talking about 
providing practical assistance in the disclosure and investigation of grave and especially grave crimes with a visit to the scene.

At the same time, forensic investigators are entrusted with the tasks of introducing technical and forensic tools into investigative practice, using modern and high-tech forensic and special equipment in the conduct of investigative actions, including for the purpose of finding weapons, traces of crime and other material evidence.

One of the main areas of work of criminologists, as already noted, is analytical work, in particular, analysis of the state and dynamics of crime, which allows obtaining systematized information about the motives of criminal activity in a particular period or in a particular territory, ways of committing crimes, periods of time of committing, as well as instruments of crime.

It should be emphasized that the criminologists of the central office of the Investigative Committee of the Russian Federation showed themselves well in the investigation of complex non-obvious crimes, incidents and disasters that resulted in massive loss of life.

Thus, the employees of the Main Department of Criminalistics directly participated in the production of the initial set of investigative actions on the most resonant criminal cases on the facts: the crash of an aircraft en route from Egypt to St. Petersburg; descent of four carriages of a passenger train on the Yekaterinburg - Adler route; the wreck of the Far East trawler in the Sea of Okhotsk; death of people and mass destruction of property as a result of fires that occurred in the Republic of Khakassia; helicopter and seaplane crashes over the Istra reservoir; a fire in a neuropsychiatric dispensary and 23 people died in the Voronezh region and many others.

Investigators-criminologists of the Investigative Committee of the Russian Federation are doing a lot of work to solve crimes against minors.

In cooperation with the operational units of the Ministry of Internal Affairs of Russia and the public, in addition to the above-mentioned crimes, a number of other high-profile socially dangerous acts were disclosed, including the murder of minors - Prokopenko (Stavropol Territory), Baburkevich (Trans-Baikal Territory), Shkaptsova (Bryansk Region), Rudakova (Rostov region), as well as many sexual crimes against minors in Irkutsk, Moscow, Tula regions and other regions.

Young investigators must always keep the experience of investigating such complex crimes "at hand".

The arsenal of forensic departments of the Investigative Committee of the Russian Federation has been replenished with high-tech equipment, both domestic and foreign, including:

mobile complexes for the collection and analysis of digital data "UFED", which allow reading information from mobile devices, as well as recovering files deleted by the user;

cyanoacrylate cameras "MISONIX CA-3000", designed to detect fingerprints; photo sets of 3D panoramic shooting "Canon";

providing the effect of the real presence of the participants in the criminal process; optical devices for detecting hidden video cameras "Optic-2";

portable high-intensity forensic light sources "Projektina SL-450", "IKS450," MIKS-450. 
Taking into account the criminogenic situation, geographic location and a number of other factors, individual criminalistics units of the investigating authorities for the constituent entities of the Russian Federation are also equipped with:

georadars (30), designed for remote detection of various metallic and non-metallic objects in various environments;

echo sounders (51) designed to detect underwater objects;

thermal imagers (26), the main task of which is to detect heat-contrast objects;

nonlinear locators (51), which search for electronic devices (mobile and others);

portable analyzers of vapors of explosives (17), designed to search for explosives, traces of their storage or carrying;

pneumatic modules (46) with a complete life support system, designed to work in remote areas when investigating man-made disasters and major accidents, as well as other equipment.

This makes it possible to solve the whole range of tasks facing the investigative bodies of the Investigative Committee of the Russian Federation.

As for the methodological support, it was only in 2016 that methodological recommendations were prepared:

"Investigation of crimes against sexual freedom and sexual inviolability of minors, committed using the Internet";

"Peculiarities of conducting pre-investigation checks, investigating criminal cases on the facts of suicides and attempted suicides of minors";

"The procedure for conducting a forensic medical examination and the establishment of causal relationships on the facts of failure to provide or inappropriate provision of medical care in the investigation of iatrogenic crimes";

"On increasing the efficiency of using forensic records in the disclosure and investigation of crimes."

It should also be noted that the activity of the study rooms of criminalistics of the investigative authorities is being actively carried out, in which a significant number of investigators, forensic investigators and heads of investigative departments have increased their level of professional training.

For the training of investigators in classrooms, among other things, the programs "Virtual inspection of the scene: educational and methodological complex" (which is available in all investigative bodies), "Virtual search (seizure): educational and methodological complex" are used.

The use of these programs clearly demonstrates the already existing skills of investigative officers in carrying out these investigative actions and helps to eliminate shortcomings.

Training videos are being created to help budding investigators.

In addition, the General Directorate of Criminalistics has developed and sent for implementation to the investigating authorities a typical program of internship for investigators: "Inspection of the scene: work with traces, procedural registration." This program is designed to improve the level of knowledge of employees with work experience of up to one year. Training assumes that the investigator assimilates the peculiarities of the tactics of inspecting the scene of 
the incident in various categories and methods of committing crimes, acquiring skills in working with technical means for identifying, fixing and removing traces, the ability to build versions, as well as competent procedural execution of investigative actions.

I will touch upon another extremely important issue for the whole society the protection of the rights of minors.

In 2016, investigators of the Investigative Committee investigated almost 19 thousand crimes, the victims of which were children, of which 464 were murders and more than 6 thousand were rapes and facts of sexual violence.

The problem of child suicides, as a result of which 720 teenagers died, became especially acute in the past year.

The greatest danger, as you know, today is represented by the actions of persons disseminating information on the Internet that promotes the theme of suicide, popularizes the aesthetics of death and encourages minors to commit suicide.

The Investigative Committee of the Russian Federation has brought charges against the administrator of one of the so-called "death groups", registered under the network name "Philip Lis". He is currently in custody.

At the same time, most people like him manage to evade responsibility, since the actions they commit are not always covered by the objective side of the crime provided for in Article 110 of the Criminal Code of the Russian Federation (Driving to suicide).

I believe that in order to effectively prevent such crimes, criminal liability should be introduced for inducement to commit suicide, in particular, by disseminating relevant information using electronic or information and telecommunication networks, including the Internet.

Thanks to the active position of the Deputy Chairman of the State Duma Irina Anatolyevna Yarovaya, the proposals of the Investigative Committee found support at the site of the interdepartmental working group, which developed the corresponding draft federal law. All law enforcement and other state bodies acted in a united front on this issue, supporting such an initiative.

On February 22, 2017, the Investigative Committee approved the official response of the Government of the Russian Federation, which supported the said draft federal law.

In addition, by decision of the Council of the State Duma, a parliamentary group was created to prepare a comprehensive draft federal law aimed at strengthening measures to protect children from sexual violence, in which we also take an active part. We have presented proposals on the non-application of the statute of limitations to crimes against the sexual inviolability of minors, as well as on the establishment of criminal liability for harboring crimes of medium and serious gravity against children.

In our multinational and multi-confessional country, it is imperative to take a systematic approach to the development of measures to counter extremism and terrorism. 
As you know, a law on blocking extremist websites was adopted (Federal Law of December 28, 2013 No. 398-FZ "On Amendments to the Federal Law" On Information, Information Technologies and on the Protection of Information"), and in November 2014 The President of the Russian Federation approved the Strategy for Countering Extremism in the Russian Federation.

This allows the Investigative Committee of the Russian Federation, together with other state bodies, primarily with the Federal Service for Supervision in the Sphere of Communications, Information Technology and Mass Media (Roskomnadzor), the General Prosecutor's Office of the Russian Federation and the Ministry of Justice of the Russian Federation, to promptly respond to provocations of extremists using Internet resources for inciting ethnic and religious hatred. Allows you to delete information containing calls for riots, the implementation of extremist activities, participation in mass (public) events held in violation of the established order.

Despite this, the situation in the field of countering extremism and terrorism in Russia is still difficult - the number of extremist crimes in 2016 increased by $11 \%(1,161$ crimes $)$.

Investigators of the Investigative Committee initiated 882 criminal cases on crimes of an extremist nature and 283 cases on crimes of a terrorist nature. 522 criminal cases on extremism and 98 on terrorism were sent to the court.

The complex operational situation requires coordinating the efforts of all structures countering extremism and terrorism, tightening control of migration flows, suppressing recruitment activities by international terrorist organizations, and eliminating resource and financial support for bandit groups.

Taking into account the existing facts of departure from Russia to "hot spots" of radically minded persons, primarily among young people to participate in hostilities on the side of the militants, it is necessary to strengthen anti-extramist work with the participation of representatives of the territorial divisions of the Ministry of Education and science, internal affairs bodies, Roskomnadzor, Rosmolodezh and Rospechat.

It is necessary to involve the public and the media, youth and student organizations, volunteers, teaching staff of universities more widely, and in the most problematic regions - to initiate preventive work at the school level.

For citation: Bastrykin A.I. Issues of increasing the efficiency of organizing the work of investigative bodies of the Investigative Committee of the Russian Federation: lecture // Legal thought. 2021. No. 3 (123). P. 111-122.

DOI: $10.47905 /$ MATGIP.2021.123.3.005

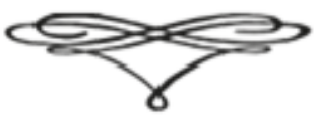




\title{
ПЕРСОНАМИИ
}

\section{удк 340}

ББK 67.0

DOI: 10.47905/MATGIP.2021.123.3.009

\section{Внктору Петровнчу Gамьннкову НСПОАняетСя 75 мет}

\author{
G.Н. Захарцев \\ G.ब. Комаров" \\ ब.Г. Хавнвуинн"
}

\begin{abstract}
Аннотация. Статья посвящена юбилею доктора юридических наук, профессора, академика, заслуженного деятеля науки Российской Федерации, почетного сотрудника органов внутренних дел, многолетнего чмена экспертного совета BAK, бывшего начальника Санкт-Петербургского университета МВД России генерал-лейтенанта милиции в отставке - Виктора Петровича Сальникова.
\end{abstract}

Ключевые слова: Сальников В.П., философия, юриспруденция, юридические науки.

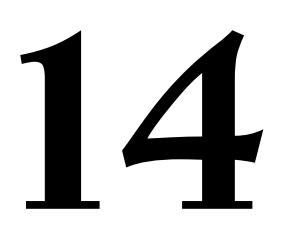

сентября 2021 года исполнимось 75 мет выдающемуся российскому юристу, доктору юридических наук, профессору, академику, заслуженному деятелю науки Российской Федерации, почетному сотруднику органов внутренних дел, многометнему чиену экспертного совета ВАК, бывшему начальнику Санкт-Петербургского университета МВД России генерал-лейтенанту мимиции в отставке Виктору Петровичу Сальникову.

Виктор Петрович родился в 1946 году в селе Колояр Вольского района Саратовской области. В 1973 году окончил Высшее политическое учимище МВД СССР и в том же году - Всесоюзный юридический заочный институт. В 1968-1969 годах проходиц службу в доцжности оперуполномоченного отдема БХСС г. Куйбышева. С 1969 по 1992 год служил в Высшем

* Захариев Сергей Иванович, заведующий кафедрой адвокатуры и правоохранительной деятельности Российского государственного социального университета, доктор юридических наук, академик PAEH. E-mail: Sergeyivz@yandex.ru

** Комаров Сергей Александрович, научный руководитель Юридического института (Санкт-Петербург), профессор кафедры теории государства и права Института права Башкирского государственного университета, президент МОО «Межрегиональная ассоциация теоретиков государства и права", доктор юридических наук, профессор. E-mail: SVKomarov2008@yandex.ru

*** Хабибулин Алик Галимзянович, заведующий кафедрой экономических и финансовых расследований Высшей школы государственного аудита (факультета) МГУ им. М.В. Аомоносова, профессор кафедры теории государства и права и политологии юридического факультета МГУ им. М.В. Аомоносова, доктор юридических наук, профессор. E-mail: 21alik@mail.ru 
политическом училище МВД СССР, пройдя путь от слушателя до начальника кафедры уголовного и гражданского права. В 1992-1997 годах - заместитель начальника Санкт-Петербургского юридического института по научной работе. В 1997-1998 годах - заместитель начальника СанктПетербургской академии МВД России.

В 1998 году Правительством Российской Федерации было принято решение объединить несколько вузов МВД Северо-Западного региона в один Санкт-Петербургский университет МВД России. Так было создано уникальное высшее учебное заведение, осуществцявшее подготовку научнопедагогических кадров, руководителей горрайорганов внутренних дел, сотрудников дмя следственных и оперативных подраздемений, воспитательных аппаратов и подразделений психомогического обеспечения деятельности органов внутренних дел, финансово-экономических и контрольноревизионных подразделений МВД России, Государственной противопожарной службы, других министерств и ведомств России. Здесь же готовились офицерские кадры дия внутренних войск МВД России. Санкт-Петербургский университет МВД России стал самым крупным вузом в системе МВД.

Возглавить этот университет поручими одному из самых известных и авторитетных ученых в системе МВД и в целом России - Виктору Петровичу Сальникову. И не ошиблись.

За время руководства Санкт-Петербургским университетом МВД России В.П. Сальников превратил его в вуз, известный во всем мире. Санкт-Петербургский университет МВД России многие российские и зарубежные специалисты называли Центом российской правовой науки. И это соответствовало действительности. По подготовке и достижениям этот совсем молодой и причем ведомственный университет успешно конкурировал с юридическими факультетами МГУ и СПбГУ.

На базе университета В.П. Сальниковым было создано несколько диссертационных советов на соискание ученой степени доктора наук. Защищаться в этих советах было очень престижно и почетно. В.П. Сальников руководим нескоцькими диссертационными советами. Под его научным консультированием подготовлено более 20 докторских и более 200 кандидатских диссертаций. Среди них не только российские граждане, но и иностранные ученые, в том числе из США, Финляндии, Афганистана, Монгомии, Йемена и других стран.

В.П. Сальников прославился своими научными достижениями. Он автор и редактор более тысячи научных и учебно-методических работ. Его книги были переведены на английский, немецкий, французский, другие языки, получими признание за рубежом. В настоящее время в мире едва $и ~$ найдется библиотека, в которой нет хотя бы одной книги В.П. Сальникова!

Они представлены в библиотеках престижнейших университетов США, Великобритании, Франции, Германии, Израиля, Китая, Монголии, всех государств СНГ, они имеются даже на Кубе и Кипре. Их изучают, по ним учатся, их используют в работе мимиионы человек! Академики В.Н. Кудрявцев и В.А. Туманов называли его отцом правовой культуры. Именно он впервые в Советском Союзе поднял на уровень диссертационных исследований проблемы теории и методологии правовой культуры, обосновал пра- 
вовую культурологию [38; 39]. Отцом российской правовой культуры сейчас называют В.П. Сальникова почти все.

В настоящее время В.П. Сальников, по рейтингам и индексу Хирша, занимает первое место по цитируемости его научных трудов среди всех юристов России (по состоянию на 1 сентября 2021 г. в системе РИНЦ зарегистрировано 37333 ученых-юристов)! Имеет уникальный индекс цитируемости трудов - 82!

В.П. Сальников многократно привлекался дия работы в российском парламенте. Он автор нескольких законопроектов по улучшению правовой защищенности Российских граждан. Кроме того, будучи одним из самых авторитетных российских юристов, В.П. Сальников выступал и выступает экспертом законопроектов. И нередко, именно его мнение является кАючевым в рассмотрении того или иного предложения законодателей.

Авторитет ученого всегда непроизвольно оформияется его официальным признанием. В.П. Сальников явцяется вице-президентом Российского союза юристов, вице-президентом Российской академии юридических наук, вице-президентом Академии пробцем безопасности, обороны и правопорядка, академиком Международной академии наук экологии и безопасности жизнедеятельности, академиком Международной академии акмеологических наук, академиком Национальной академии ювенологии, академиком Санкт-Петербургской инженерной академии, член-корреспондентом Российской академии ракетных и артилмерийских наук. В.П. Сальников победитель международного конкурса "Человек года" в номинации "Юрист года - 2001». Включен в международное издание Кембриджского университета "Выдающиеся мюди ХХ века".

С 2001 года В.П. Сальников является академиком Российской академии естественных наук, диительное время возглавляет в ней секцию “Безопасность человека, общества и государства". Эта секция объединяет ведущих российских специалистов, посвятивших свою научную и практическую работу вопросам защиты мюдей. Работа этой секции видна во всем мире.

В.П. Сальников, кроме того - Заслуженный деятель науки Российской Федерации, Почетный работник МВД России, Почетный работник высшего профессионального образования Российской Федерации, генерал-лейтенант милиции в отставке, награжден государственными, ведомственными и научными наградами, а также наградами Русской православной церкви.

Таким же ярким Виктор Петрович явцяется не только в науке, но

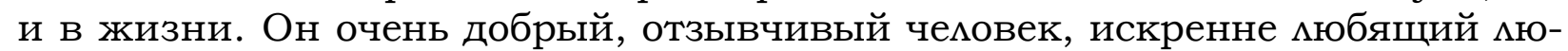
дей. Уметь не зАиться на мюдей, относиться к ним с пониманием и мюбовью - это основа доброты. И именно доброту Виктора Петровича сумели ощутить на себе все его друзья, знакомые, сослуживцы, подчиненные. Даже будучи всемирно известным ученым и начальником университета, доступ в его приемную был открыт всем.

В 2015 году о В.П. Сальникове вышиа объемная книга, которую так и назвали "Формула доброты" [37]. Делать мюдям добро - главное кредо жизни Виктора Петровича.

Юбиляр, помимо того, отмичный друг. Он умеет дружить по-настоящему: искренне, открыто, без камня за пазухой. Все близкие мюди знают, 
насколько он является надежным человеком, что в настоящее время, увы, встречается не часто.

Виктор Петрович также явцяется прекрасным семьянином, отцом известного ученого, доктора юридических наук, профессора М.В. Сальникова и воспитателем пятерых внуков. Со своей супругой Татьяной они живут уже много мет доцго и счастииво!

Свои 75 мет юбиляр встречает на пике своей научной активности. Он совместно с С.И. Захарцевым обосновал и разрабатывает компрехендную теорию права - новую теорию права $[1 ; 4 ; 6 ; 18 ; 22 ; 23 ; 24 ; 25 ; 53]$, получившую широкую известность в России и за рубежом.

Помимо этого, за крайние пять мет В.П. Сальников и С.И. Захарцев сформулировали критерии правового прогресса $[10 ; 15 ; 16]$; определили новые типы проявмений профессиональной деформации в отдемьных профессиях (в том числе у юристов, преподавателей, оперативных сотрудников спецслужб) [19]; показали проявления бессмысленности и глупости в праве $[11 ; 13 ; 14]$; установили особенности правовой ментальности и правового нигилизма россиян [17]; исследовали теорию конвергенции государственно-правовых систем [7; 9; 26] и оперативно-розыскную политику $[2 ; 3 ; 4 ; 5$; $8 ; 12 ; 26 ; 27 ; 28 ; 30 ; 41]$. ДАя фримософиии - сформулировали и продолжают разрабатывать проблему становления мичности ученого и его научных позиций [20; 40], а также гипотезу катаклизмов и круговорота жизни на Земле [21]. Кроме этого, они исследуют философию Парменида, Гегеля и Ф.М. Достоевского $[29 ; 34 ; 35 ; 36 ; 43 ; 44 ; 45 ; 48 ; 51 ; 54]$, разрабатывают вопросы фимософии права, суверенитета, свободы, российской правовой идеологии [30; 31; 32; 33; 42; 46; 47; 49; 50; 52].

В настоящее время В.П. Сальников явцяется главным редактором таких известных научных журналов как: "Юридическая наука: история и современность", "Мир политики и социологии", "Правовое поле современной экономики".

Юбиляр, кроме того, является оптимистом и жизнелюбом. От него просто веет положительной энергией и стремлением жить полной жизнью. От всего сердца авторов и членов редкомлегии журнала "Юридическая мысль", членов Межрегиональной ассоциации теоретиков государства и права, желаем дорогому Виктору Петровичу домгих мет жизни, здоровья и счастья!

\section{Бибциографический список}

1. Захарцев С.И. Некоторые проблемы теории и фимософии права / Под общ. ред. В.П. Сальникова. - М., 2014.

2. Захарцев С.И., Сальников В.П. Вненаучное знание в оперативнорозыскной деятельности // Правовое поле современной экономики. - 2013. № 10. - С. 193-199.

3. Захарцев С.И., Сальников В.П. Использование результатов оперативнорозыскной деятельности в доказывании по уголовному делу: перспективы законодательной регламентации // Конституционные аспекты современного состояния законодательства Республики Таджикистан: материалы международной научно-теоретической конференции. - Душанбе: Ирфон, 2014. - С 90-93. в сб. 243 с. 
4. Захарцев С.И., Сальников В.П. Как познать право? Мы предлагаем компрехендный подход // Правовое поле современной экономики. - 2015. - № 9. C. $17-30$.

5. Захарцев С.И., Вихров В.А., Игнащенков Ю.Ю., Сальников В.П. Оперативно-розыскная деятельность и военная безопасность / Под ред. С.И. Захарцева: Монография. - М.: Граница, 2017. - 424 с.

6. Захарцев С.И., Сальников В.П. Размышляем о сущности права: компрехендный подход // Правовое государство: теория и практика. 2017. Т. 1. № 47. C. $13-30$.

7. Захарцев С.И., Сальников В.П. Конвергенция в праве, русская ментальность и психомогия нищенства: философская и философско-правовая проблема // Мир политики и социологии. - 2015. - № 1. - С. 166-179.

8. Захарцев С.И., Сальников В.П. Конституционные права человека в России и допустимость их ограничения в ходе проведения оперативно-розыскных мероприятий на каналах связи // Конституционные аспекты современного состояния законодательства Республики Таджикистан: материалы международной научно-теоретической конференции. - Душанбе: Ирфон, 2014. - С 84-89. - в сб. 243 c.

9. Захарцев С.И., Сальников В.П. Конвергенция норм права и правовое государство // Правовое государство: теория и практика. 2019. № 1 (55). С. 22-27.

10. Захарцев С.И., Сальников В.П. О правовом прогрессе как философскоправовой проблеме // Российский журнал правовых исследований. - 2015. № 2(3). - C 113-121.

11. Захарцев С.И., Сальников В.П. О разумности и бессмысленности права // Известия Российской академии ракетных и артимлерийских наук. - 2016. № 4(94).

12. Захарцев С.И., Сальников В.П. Оперативно-розыскная экономика и оперативно-розыскная политика // Правовое поле современной экономики. - 2015. № 12 . - C. 11-15.

13. Захарцев С.И., Сальников В.П. Право может быть и бессмысленным // Защита и безопасность. - 2016. - № 3.

14. Захарцев С.И., Сальников В.П. Право: разумность и бессмысленность // Юридическая наука: история и современность. - 2015. - № 9. - С. 17-22.

15. Захарцев С.И., Сальников В.П. Правовой прогресс и ценности права // Мир политики и социологии. - 2015. - № 9. - С. 17-31.

16. Захарцев С.И., Сальников В.П. Правовой прогресс: философский и фимософско-правовой подходы // Правовое поле современной экономики. - 2015. № $1 .-$ C. 13-30.

17. Захарцев С.И., Сальников В.П. Правосознание юриста и правовой нигимизм: современные проблемы профессиональной деформации // Юридическая наука: история и современность. - 2013. - № 11. - С. 11-29.

18. Захарцев С.И., Сальников В.П. Что такое право? Вопросы онтологии и гносеологии // Правовое государство: теория и практика. 2015. № 2 (40). С. 14-22.

19. Захарцев С.И., Сальников В.П. Профессиональная деформация правосознания ученых-юристов: некоторые размышления по итогам исследования // Юридическая наука: история и современность. - 2015. - № 11. - С. 172-180.

20. Захарцев С.И., Сальников В.П. Становление мичности ученого и его научные позиции: взаимосвязь и взаимозависимость // Мир политики и социологии. - 2016. - № 2. - С. 11-17.

21. Захарцев С.И., Сальников В.П. Тезисно о философских проблемах познания Вселенной и Земли // Правовое поле современной экономики. - 2015. № 10. - С. 171-180. 
22. Захарцев С.И., Сальников В.П. Фимософия. Фицософия права. Юридическая наука. - М.: Юрлитинформ, 2015. - 264 с.

23. Захарцев С.И., Сальников В.П. Что есть компрехендная теория права? // Юридическая наука. - 2016. - № 3.

24. Захарцев С.И., Сальников В.П. Что такое право? Вопросы онтологии и гносеологии // Правовое государство: теория и практика. - 2015. - № 2(40). C. $14-22$.

25. Захарцев С.И., Сальников В.П. Философия и юридическая наука: Монография. - М.: Юрмитинформ, 2019. - 424 с. 26,5 п.л.

26. Захарцев С.И., Игнащенков Ю.Ю., Сальников В.П. Оперативнорозыскная деятельность в XXI веке: Монография. - М., 2015. - 400 с.

27. Захарцев С.И., Игнащенков Ю.Ю., Сальников В.П. Оперативнорозыскные мероприятия в XXI веке: Монография. - СПб., 2006. - Серия: «Теория и практика оперативно-розыскной деятельности" / МВД России, С.-Петерб. ун-т.

28. Захарцев С.И., Медведев В.Н., Сальников В.П. Снятие информации с технических каналов связи: правовые вопросы / Санкт-Петербургский университет МВД России; Академия права, экономики и безопасности жизнедеятельности; под общей редакцией В.П. Сальникова. - СПб., 2004.

29. Захарцев С.И., Масленников Д.В., Сальников В.П. Аогос права: Парменид - Гегель - Достоевский. К вопросу о спекумятивно-логических основаниях метафизики права: монография. - М.: Юрлитинформ, 2019. - 376 с.

30. Захарцев С.И. Сальников В.П. Русский менталитет и право // Правовое государство: теория и практика. 2018. № 4 (54). С. 41-47.

31. Захарцев С.И., Сальников В.П. Фимософия права: юридические позиции // Правовое государство: теория и практика. 2016. № 1 (43). С. 19-26.

32. Захарцев С.И. Сальников В.П. Фимософия права: настоящее и будущее // Правовое государство: теория и практика. 2016. № 2 (44). С. 7-14.

33. Захарцев С.И., Сальников В.П. Философия права: вчера, сегодня, завтра // Правовое государство: теория и практика. 2015. № 4 (42). С. 6-13.

34. Идея свободы. Право. Мораль (классическая и постклассическая философия права): монография / Ананских И.А., Грибов И.Н., Захарцев С.И., Зорина Н.В., Исмагилов И.Р., Клименко О.А., Һежнева О.Ю., Мазурин С.Ф., Маков Б.В., Масленников Д.В., Мирзоев И.К., Петров И.А., Поливко Е.А., Прокофьев К.Г., Пымева О.В., Сальников В.П., Сальников М.В., Чудин-Коган Ф.О.; под ред. С.И. Захарцева. - М.: Юрлитинформ, 2020. - 288 с.

35. Захарцев С.И., Масленников Д.В., Сальников В.П. Теоретико-методологические основания философии права Ф.М. Достоевского как идеолога "предъевразийства" // Правовое государство: теория и практика. 2019. № 2 (56). С. 17-24.

36. Захарцев С.И., Масленников Д.В., Сальников В.П. Теоретико-методологические основания философии права Ф.М. Достоевского как идеолога "предъевразийства" // Правовое государство: теория и практика. - 2019. - № 2 (56). C. 17-24.

37. Аапина Н.В., Моргунов В.Я. Формула доброты: Документально-художественная книга. - М.-СПб.: Фонд "Университет", 2015. - 468 с. + 64 имл.

38. Сальников В.П. Правовая культура и поведение советских граждан: Дис. ... канд. юрид. наук. $-\Lambda ., 1980$.

39. Сальников В.П. Правовая культура: теоретико-методологический аспект: Дис. ... докт. юрид. наук. - А., 1990.

40. Сальников В.П., Захарцев С.И. Роль биографии ученого в формировании его жизненной позиции, мировоззрения и методологии // Известия Российской академии ракетных и артилмерийских наук. - 2016. - № 2 (92). 
41. Сальников В.П., Захарцев С.И. Тезисно об актуальных проблемах науки оперативно-розыскной деятельности // Оперативник (сыщик). - 2015. - № 1(42). C. 35-37.

42. Сальников В.П., Романовская В.Б., Фомичев М.Н. Право и научнотехнический прогресс: вместе или отдельно // Мир политики и социологии. 2016. - № 2. - С. 175-193

43. Сальников В.П., Масленников Д.В. Фимософия права Ф.М. Достоевского как источник развития теории российского государства и права // Проблемы статуса современной России: историко-правовой аспект: материалы Всероссийской научно-практической конференции (г. Уфа, 5-6 апреля 2018 г.) / Отв. ред. Ф.Х. Галиев. В 2-х ч. Ч. 1. - Уфа: РИЦ БашГУ, 2018. - С. 72-79. - в сб. 256 с.

44. Сальников В.П., Масленников Д.В., Захарцев С.И. Ф.М. Достоевский: онтологические и этические основания философии права (рецензия на работу Р.Ф. Исмагимова "Философское наследие Ф.М. Достоевского и его вцияние на развитие фимософии права: Цикл мекций») // Юридическая наука: история и современность. - 2017. - № 7. - С. 190-197.

45. Сальников В.П., Масленников Д.В., Захарцев С.И. Философия Гегеля как теоретическая предпосылка суверенной философии права России. Краткий обзор докладов, статей и выступлений на Межрегиональной конференции с международным участием "Творческое наследие Гегеля: философия, теология, право, экономика", посвященной 250-летию со дня рождения Г.В.Ф. Гегеля // Юридическая наука: история и современность. - 2021. - № 1 .

46. Сальников В.П., Масленников Д.В., Морозов А.И. Человек в системе нравственно-правовых ценностей и задача формирования суверенной фимософии права // Права чемовека в диалоге государственной власти и гражданского общества: Сборник материалов Всероссийской научно-практической конференции, посвященной Дню прав человека (г. Уфа, 10 декабря 2020 г.). В 2-х частях. Ч. 1 / Отв. ред. Е.О. Тулупова. - Уфа: РИЦ БашГУ, 2020. - Уфа, 2020. - С. 176-187. в сб. 243 с.

47. Сальников В.П., Захарцев С.И., Масленников Д.В., Морозов А.И. К вопросу об историко-философских основаниях суверенной философии права как формы выражения национальных социально-правовых ценностей // Мир политики и социологии. 2018. № 11. С. 174-180.

48. Сальников В.П., Исмагилов Р.Ф., Масленников Д.В., Захарцев С.И. Фимософия Ф.М. Достоевского как объект интерпретирующей реконструкции // Мир политики и социологии. - 2018. - № 9-10. - С. 171-183.

49. Сальников В.П., Масленников Д.В., Захарцев С.И., Морозов А.И. Ценностное основание суверенитета (к вопросу о суверенной государственно-правовой идеологии) // Юридическая наука: история и современность. - 2019. - № 11. C. $149-162$.

50. Сальников В.П., Масленников Д.В., Захарцев С.И., Сальников М.В. Развитие идеи абсолютной свободы в классической русской философии как источник суверенной фимософии права / 2019. - № 12. - C. 185-193.

51. Сальников В.П., Исмагилов Р.Ф., Масленников Д.В., Захарцев С.И., Морозов А.И. "Пушкинская речь" Достоевского и нравственная идея государства (К 140-летию выступления Ф.М. Достоевского) // Юридическая наука: история и современность. - 2020. - № 11. - С. 163-180.

52. Сальников В.П., Масленников Д.В., Захарцев С.И., Прокофьев К.Г., Морозов А.И. Принцип суверенности государственно-правовой идеологии и философии права // Мир политики и социологии. - 2019. - № 9. - С. 170-178. 
53. Zakhartsev S.I., Salnikov V.P. The Philosophy of Law and Legal Science. Newcastle upon Tyne: Cambridge Scholars Publishing, 2018. 270 p.

54. Zakhartsev S.I., Maslennikov D.V., Salnikov V.P. The Logos of Law: Parmenides - Hegel - Dostoevsky. The Speculative and Logical Foundations of the Metaphysics of Law. - London: Europe Books. 2021. - 450 p.

Дмя цитирования: Захариев С.И.. Комаров С.А., Хабибулин А.Г. Виктору Петровичу Сальникову исполняется 75 мет // Юридическая мысль. 2021. № 3 (123). С. 123-130.

DOI: $10.47905 /$ MATGIP.2021.123.3.009

\title{
Viktor Petrovich Salnikov is 75
}

\section{Sergei I. Zakhartsev* Sergey A. Komarov ** Alik G. Khabibulin ${ }^{* * *}$}

\begin{abstract}
Annotation. The article is dedicated to the anniversary of the Doctor of Law, Professor, Academician, Honored Scientist of the Russian Federation, Honorary Officer of the Internal Affairs Bodies, a long-term member of the Expert Council of the Higher Attestation Commission, former head of the St. Petersburg University of the Ministry of Internal Affairs of Russia, retired police lieutenant general - Viktor Petrovich Salnikov.
\end{abstract}

Key words: Salnikov V.P., philosophy, jurisprudence, legal sciences.

September 14, 2021 marked the 75th anniversary of the outstanding Russian lawyer, Doctor of Law, Professor, Academician, Honored Scientist of the Russian Federation, Honorary Officer of the Internal Affairs Bodies, longterm member of the Expert Council of the Higher Attestation Commission, the former head of the St. resignation to Viktor Petrovich Salnikov.

Viktor Petrovich was born in 1946 in the village of Koloyar, Volsky District, Saratov Region. In 1973 he graduated from the Higher Political School of the USSR Ministry of Internal Affairs and in the same year - the All-Union Correspondence Law Institute. In 1968-1969 he served as an operative of the BHSS department in Kuibyshev. From 1969 to 1992 he served at the Higher Political School of the Ministry of Internal Affairs of the USSR, going from a student to the head of the department of criminal and civil law. 1992-1997 Deputy Head of the St. Petersburg Law Institute for Research. 1997-1998- Deputy Head of the St. Petersburg Academy of the Ministry of Internal Affairs of Russia.

* Zakhartsev Sergei Ivanovich, Head of the Department of Advocacy and Law Enforcement, Russian State Social University, Doctor of Law, Academician of the Russian Academy of Natural Sciences. E-mail: Sergeyivz@yandex.ru

** Komarov Sergey Aleksandrovich, scientific director of the Law Institute (St. Petersburg), professor of the Department of Theory of State and Law of the Institute of Law of the Bashkir State University, President of the Interregional Association of State and Law Theorists, Doctor of Law, Professor. E-mail: SVKomarov2008@yandex.ru

*** Khabibulin Alik Galimzyanovich, Head of the Department of Economic and Financial Investigations of the Higher School of State Audit (Faculty), Moscow State University. M.V. Lomonosov, Professor of the Department of Theory of State and Law and Political Science, Faculty of Law, Moscow State University. M.V. Lomonosov, Doctor of Law, Professor. E-mail: 21alik@mail.ru 
In 1998, the Government of the Russian Federation decided to merge several universities of the Ministry of Internal Affairs of the North-West region into one - St. Petersburg University of the Ministry of Internal Affairs of Russia. This is how a unique higher educational institution was created, which trained scientific and pedagogical personnel, heads of city district bodies of internal affairs, employees for investigative and operational departments, educational apparatus and subdivisions of psychological support for the activities of internal affairs bodies, financial, economic and control and audit departments of the Ministry of Internal Affairs of Russia, State fire service, other ministries and departments of Russia. Here, officers were trained for the internal troops of the Ministry of Internal Affairs of Russia. St. Petersburg University of the Ministry of Internal Affairs of Russia has become the largest university in the system of the Ministry of Internal Affairs.

One of the most famous and authoritative scientists in the system of the Ministry of Internal Affairs and in the whole of Russia, Viktor Petrovich Salnikov, was entrusted to head this university. And they were not mistaken.

During the leadership of the St. Petersburg University of the Ministry of Internal Affairs of Russia, V.P. Salnikov turned it into a world-famous university. St. Petersburg University of the Ministry of Internal Affairs of Russia was called the Center of Russian Legal Science by many Russian and foreign experts. And this was true. In terms of training and achievements, this very young and, moreover, departmental university successfully competed with the law faculties of Moscow State University and St. Petersburg State University.

On the basis of the university, V.P. Salnikov created several dissertation councils for the degree of Doctor of Science. It was very prestigious and honorable to defend oneself in these councils. V.P. Salnikov directed several dissertation councils. More than 20 doctoral and more than 200 master's theses have been prepared under his scientific advice. Among them are not only Russian citizens, but also foreign scientists, including those from the USA, Finland, Afghanistan, Mongolia, Yemen and other countries.

V.P. Salnikov became famous for his scientific achievements. He is the author and editor of over a thousand scientific and educational works. His books have been translated into English, German, French and other languages, and have gained recognition abroad. At present, there is hardly a library in the world that does not contain at least one book by V.P. Salnikov!

They are presented in the libraries of the most prestigious universities in the USA, Great Britain, France, Germany, Israel, China, Mongolia, all CIS countries, they are even available in Cuba and Cyprus. They are studied, they are taught, they are used in work by millions of people! Academicians V.N. Kudryavtsev and V.A. Tumanov called him the father of legal culture. It was he who for the first time in the Soviet Union raised the problems of theory and methodology of legal culture to the level of dissertation research, substantiated legal culturology [38; 39]. The father of Russian legal culture is now called V.P. Salnikov, almost everything.

Currently V.P. According to ratings and the Hirsch index, Salnikov ranks first in the citation of his scientific works among all lawyers in Russia (as of September 1, 2021, 37333 legal scholars are registered in the RSCI system)! Has a unique citation index of works -82 ! 
V.P. Salnikov was recruited many times to work in the Russian parliament. He is the author of several bills to improve the legal protection of Russian citizens. In addition, being one of the most respected Russian lawyers, V.P. Salnikov has acted and is an expert on draft laws. And often it is his opinion that is key in considering a particular proposal of legislators.

The authority of a scientist is always involuntarily formed by his official recognition. V.P. Salnikov is Vice President of the Russian Union of Lawyers, Vice President of the Russian Academy of Legal Sciences, Vice President of the Academy of Security, Defense and Law Enforcement, Academician of the International Academy of Sciences of Ecology and Life Safety, Academician of the International Academy of Acmeological Sciences, Academician of the National Academy of Juvenology, Academician of St. -Petersburg Engineering Academy, Corresponding Member of the Russian Academy of Rocket and Artillery Sciences. V.P. Salnikov is the winner of the international competition "Person of the Year" in the nomination "Lawyer of the Year - 2001". Included in the international publication of the University of Cambridge "Outstanding People of the Twentieth Century".

Since 2001 V.P. Salnikov is an academician of the Russian Academy of Natural Sciences, for a long time he has headed the section "Security of man, society and state". This section brings together leading Russian experts who have devoted their scientific and practical work to the protection of people. The work of this section is visible all over the world.

V.P. Salnikov, in addition, Honored Scientist of the Russian Federation, Honorary Worker of the Ministry of Internal Affairs of Russia, Honorary Worker of Higher Professional Education of the Russian Federation, retired police lieutenant general, was awarded state, departmental and scientific awards, as well as awards of the Russian Orthodox Church.

Viktor Petrovich is just as bright not only in science, but also in life. He is a very kind, sympathetic person who sincerely loves people. To know how not to get angry with people, to treat them with understanding and love is the basis of kindness. And it was Viktor Petrovich's kindness that all his friends, acquaintances, colleagues, and subordinates were able to feel. Even as a world famous scientist and head of the university, access to its reception room was open to everyone.

In 2015 about V.P. Salnikov, a voluminous book was published, which was called the "Formula of Kindness" [37]. Doing good to people is the main credo of Viktor Petrovich's life.

The hero of the day is also a great friend. He knows how to be friends for real: sincerely, openly, without a stone in his bosom. All close people know how reliable he is, which at the present time, alas, is not often met.

Viktor Petrovich is also an excellent family man, the father of a famous scientist, Doctor of Law, Professor M.V. Salnikov and educator of five grandchildren. They live happily ever after with their wife Tatyana!

The jubilee celebrates his 75th birthday at the peak of his scientific activity. Together with S.I. Zakhartsev substantiated and develops a comprehensive theory of law - a new theory of law [1; 4; 6; eighteen; 22; 23;24; 25; 53], which has become widely known in Russia and abroad. 
In addition, over the past five years V.P. Salnikov and S.I. Zakhartsev formulated criteria for legal progress $[10 ; 15 ; 16]$; identified new types of manifestations of professional deformation in certain professions (including lawyers, teachers, operational intelligence officers) [19]; showed manifestations of meaninglessness and stupidity in law $[11 ; 13$; fourteen]; identified the features of the legal mentality and legal nihilism of Russians [17]; investigated the theory of convergence of state and legal systems [7; nine; 26] and the operational-search policy [2; 3; 4; 5; eight; $12 ; 26 ; 27 ; 28$; thirty; 41]. For philosophy, they have formulated and continue to develop the problem of the formation of the personality of a scientist and his scientific positions [20;40], as well as the hypothesis of cataclysms and the cycle of life on Earth [21]. In addition, they study the philosophy of Parmenides, Hegel and F.M. Dostoevsky [29;34; 35; $36 ; 43 ; 44 ; 45 ; 48 ; 51 ; 54]$, develop questions of philosophy of law, sovereignty, freedom, Russian legal ideology [30; 31; 32; 33; 42; 46; 47; 49; 50; 52].

Currently V.P. Salnikov is the editor-in-chief of such well-known scientific journals as "Legal Science: History and Modernity", "The World of Politics and Sociology", "Legal Field of the Modern Economy".

The hero of the day, in addition, is an optimist and lover of life. He just exudes positive energy and the desire to live life to the fullest. From the bottom of our hearts, the authors and members of the editorial board of the journal "Legal Thought", members of the Interregional Association of Theorists of State and Law, we wish dear Viktor Petrovich many years of life, health and happiness!

\section{Bibliographic list}

1. Zakhartsev S.I. Some problems of theory and philosophy of law / Under total. ed. V.P. Salnikov. Moscow, 2014.

2. Zakhartsev S.I., Salnikov V.P. Extra-scientific knowledge in operationalsearch activity // Legal field of modern economics. 2013. No. 10. P. 193-199.

3. Zakhartsev S.I., Salnikov V.P. Using the results of operational-search activities in proving a criminal case: prospects for legislative regulation // Constitutional aspects of the current state of the legislation of the Republic of Tajikistan: materials of an international scientific-theoretical conference. - Dushanbe: Irfon, 2014. P 90-93.

4. Zakhartsev S.I., Salnikov V.P. How to know the right? We offer a comprehensive approach // Legal field of modern economy. 2015. No. 9. P. 17-30.

5. Zakhartsev S.I., Vikhrov V.A., Ignaschenkov Yu.Yu., Salnikov V.P. Operational-search activity and military security / Ed. S.I. Zakhartseva: Monograph. Moscow: Granitsa, 2017. 424 p.

6. Zakhartsev S.I., Salnikov V.P. Reflecting on the essence of law: a comprehensive approach // Legal state: theory and practice. 2017. Vol. 1. No. 47. P. 13-30.

7. Zakhartsev S.I., Salnikov V.P. Convergence in law, Russian mentality and psychology of begging: a philosophical and philosophical-legal problem // World of Politics and Sociology. 2015. No. 1. P. 166-179.

8. Zakhartsev S.I., Salnikov V.P. Constitutional human rights in Russia and the admissibility of their limitation in the course of operational-search activities on communication channels // Constitutional aspects of the current state of the legislation of the Republic of Tajikistan: materials of an international scientific-theoretical conference. Dushanbe: Irfon, 2014. P. 84-89. 
9. Zakhartsev S.I., Salnikov V.P. Convergence of the rule of law and the rule of law // The rule of law: theory and practice. 2019. No. 1 (55). P. 22-27.

10. Zakhartsev S.I., Salnikov V.P. On legal progress as a philosophical and legal problem // Russian Journal of Legal Research. 2015. No. 2 (3). P. 113-121.

11. Zakhartsev S.I., Salnikov V.P. On the rationality and meaninglessness of law // News of the Russian Academy of Rocket and Artillery Sciences. 2016. No. 4 (94).

12. Zakhartsev S.I., Salnikov V.P. Operational-search economy and operationalsearch policy // Legal field of modern economics. 2015. No. 12. P. 11-15.

13. Zakhartsev S.I., Salnikov V.P. The right can be meaningless // Protection and security. 2016. No. 3.

14. Zakhartsev S. I., Salnikov V. P. Law: reasonableness and meaninglessness / / Legal science: history and modernity. - 2015. - No. 9. P. 17-22.

15. Zakhartsev S. I., Salnikov V. P. Legal progress and the values of law // The world of politics and sociology. - 2015. - P. 17-31.

16. Zakhartsev S. I., Salnikov V. P. Legal progress: philosophical and philosophical-legal approaches / / The legal field of modern economics. - 2015. - No. 1. - P. 13-30.

17. Zakhartsev S.I., Salnikov V.P. Legal consciousness of a lawyer and legal nihilism: modern problems of professional deformation // Legal science: history and modernity. 2013. No. 11. P. 11-29.

18. Zakhartsev S.I., Salnikov V.P. What is law? Issues of ontology and epistemology // Legal state: theory and practice. 2015. No. 2 (40). P. 14-22.

19. Zakhartsev S.I., Salnikov V.P. Professional deformation of legal consciousness of legal scholars: some reflections on the results of the study // Legal science: history and modernity. 2015. No. 11. P. 172-180.

20. Zakhartsev S.I., Salnikov V.P. Formation of a scientist's personality and his scientific positions: interconnection and interdependence // World of politics and sociology. 2016. No. 2. P. 11-17.

21. Zakhartsev S.I., Salnikov V.P. Thesis on the philosophical problems of cognition of the Universe and the Earth // Legal field of modern economics. 2015. No. 10. P. 171-180.

22. Zakhartsev S.I., Salnikov V.P. Philosophy. Philosophy of Law. Legal science. Moscow: Yurlitinform, 2015. 264 p.

23. Zakhartsev S.I., Salnikov V.P. What is a compromise theory of law? // Legal Science. 2016. No. 3.

24. Zakhartsev S.I., Salnikov V.P. What is law? Issues of ontology and epistemology // Legal state: theory and practice. 2015. No. 2 (40). P. 14-22.

25. Zakhartsev S.I., Salnikov V.P. Philosophy and Legal Science: Monograph. Moscow: Jurlitinform, 2019. 424 p.

26. Zakhartsev S.I., Ignaschenkov Yu.Yu., Salnikov V.P. Operational-search activity in the XXI century: Monograph. Moscow, 2015. 400 p.

27. Zakhartsev S.I., Ignaschenkov Yu.Yu., Salnikov V.P. Operational-search activities in the XXI century: Monograph. Sankt-Petersburg, 2006. Series: "Theory and practice of operational-search activity" / Ministry of Internal Affairs of Russia, St. Petersburg. un-t.

28. Zakhartsev S.I., Medvedev V.N., Salnikov V.P. Removing information from technical communication channels: legal issues / St. Petersburg University of the Ministry of Internal Affairs of Russia; Academy of Law, Economics and Life Safety; edited by V.P. Salnikov. Sankt-Petersburg, 2004.

29. Zakhartsev S.I., Maslennikov D.V., Salnikov V.P. Logos of law: Parmenides Hegel - Dostoevsky. On the question of the speculative-logical foundations of the metaphysics of law: monograph. Moscow: Jurlitinform, 2019. 376 p. 
30. Zakhartsev S.I. Salnikov V.P. Russian mentality and law // Legal state: theory and practice. 2018. No. 4 (54). P. 41-47.

31. Zakhartsev S.I., Salnikov V.P. Philosophy of law: legal positions // Legal state: theory and practice. 2016. No. 1 (43). P. 19-26.

32. Zakhartsev S.I. Salnikov V.P. Philosophy of law: present and future // Legal state: theory and practice. 2016. No. 2 (44). P. 7-14.

33. Zakhartsev S.I., Salnikov V.P. Philosophy of law: yesterday, today, tomorrow // Legal state: theory and practice. 2015. No. 4 (42). P. 6-13.

34. The idea of freedom. Right. Moral (classical and postclassical philosophy of law): monograph / Ananskikh I.A., Gribov I.N., Zakhartsev S.I., Zorina N.V., Ismagilov I.R., Klimenko O.A., Lezhneva O. Yu., Mazurin S.F., Makov B.V., Maslennikov D.V., Mirzoev I.K., Petrov I.A., Polivko E.A., Prokofiev K.G., Pyleva O.V., Salnikov V.P., Salnikov M.V., Chudin-Kogan F.O .; ed. S.I. Zakhartseva. Moscow: Jurlitinform, 2020. $288 \mathrm{p}$.

35. Zakhartsev S.I., Maslennikov D.V., Salnikov V.P. Theoretical and methodological foundations of the philosophy of law F.M. Dostoevsky as an ideologist of "preEurasianism" // Legal state: theory and practice. 2019. No. 2 (56). P. 17-24.

36. Zakhartsev S.I., Maslennikov D.V., Salnikov V.P. Theoretical and methodological foundations of the philosophy of law F.M. Dostoevsky as an ideologist of "preEurasianism" // Legal state: theory and practice. 2019. No. 2 (56). P. 17-24.

37. Lapina N.V., Morgunov V.Ya. Formula of Kindness: A documentary-fiction book. Moscow-Sankt-Petersburg: Fund "University", 2015. 468 p. + 64 ill.

38. Salnikov V.P. Legal culture and behavior of Soviet citizens: Dis. ... Cand. jurid. sciences. L., 1980.

39. Salnikov V.P. Legal culture: theoretical and methodological aspect: Dis. ... doct. jurid. sciences. L., 1990.

40. Salnikov V.P., Zakhartsev S.I. The role of a scientist's biography in the formation of his life position, worldview and methodology // Bulletin of the Russian Academy of Rocket and Artillery Sciences. 2016. No. 2 (92).

41. Salnikov V.P., Zakhartsev S.I. Thesis on topical problems of the science of operational-search activity // Operative (detective). 2015. No. 1 (42). P. 35-37.

42. V. P. Salnikov, V. B. Romanovskaya, M. N. Fomichev. Law and Scientific and Technological Progress: Together or Separately // World of Politics and Sociology. 2016. No. 2. - P. 175-193

43. V. P. Salnikov, D. V. Maslennikov. Philosophy of law F.M. Dostoevsky as a source of development of the theory of Russian state and law // Problems of the status of modern Russia: historical and legal aspect: materials of the All-Russian scientific and practical conference (Ufa, April 5-6, 2018) / Ed. ed. F.Kh. Galiev. In 2 hours, Part 1. Ufa: RITs BashGU, 2018. Pp. 72-79.

44. Salnikov V.P., Maslennikov D.V., Zakhartsev S.I. F.M. Dostoevsky: the ontological and ethical foundations of the philosophy of law (a review of the work of RF Ismagilov "Philosophical heritage of FM Dostoevsky and its influence on the development of philosophy of law: A cycle of lectures") // Legal science: history and modernity. 2017. No. 7. P. 190-197.

45. Salnikov V.P., Maslennikov D.V., Zakhartsev S.I. Hegel's philosophy as a theoretical prerequisite for the sovereign philosophy of law in Russia. A brief overview of reports, articles and speeches at the Interregional Conference with International Participation "Hegel's Creative Legacy: Philosophy, Theology, Law, Economics" dedicated to the 250th anniversary of the birth of G.V.F. Hegel // Legal Science: History and Modernity. 2021. No. 1.

46. Salnikov V.P., Maslennikov D.V., Morozov A.I. A person in the system of moral and legal values and the task of forming a sovereign philosophy of law // Hu- 
man rights in the dialogue between government and civil society: Collection of materials of the All-Russian scientific and practical conference dedicated to Human Rights Day (Ufa, December 10, 2020). In 2 parts. Part 1 / Resp. ed. E.O. Tulupova. Ufa: RITs BashSU, 2020. Ufa, 2020. P. 176-187.

47. Salnikov V.P., Zakhartsev S.I., Maslennikov D.V., Morozov A.I. On the question of the historical and philosophical foundations of the sovereign philosophy of law as a form of expression of national social and legal values // World of Politics and Sociology. 2018. No. 11. P. 174-180.

48. Salnikov V.P., Ismagilov R.F., Maslennikov D.V., Zakhartsev S.I. Philosophy of F.M. Dostoevsky as an object of interpretive reconstruction // World of Politics and Sociology. 2018. No. 9-10. P. 171-183.

49. Salnikov V.P., Maslennikov D.V., Zakhartsev S.I., Morozov A.I. The value basis of sovereignty (on the issue of sovereign state-legal ideology) // Legal Science: History and Modernity. 2019. No. 11. P. 149-162.

50. Salnikov V.P., Maslennikov D.V., Zakhartsev S.I., Salnikov M.V. Development of the idea of absolute freedom in classical Russian philosophy as a source of sovereign philosophy of law // Legal science: history and modernity. 2019. No. 12. P. 185-193.

51. Salnikov V.P., Ismagilov R.F., Maslennikov D.V., Zakhartsev S.I., Morozov A.I. Dostoevsky's "Pushkin speech" and the moral idea of the state (To the 140th anniversary of FM Dostoevsky's speech) // Juridical science: history and modernity. 2020. No. 11. P. 163-180.

52. Salnikov V.P., Maslennikov D.V., Zakhartsev S.I., Prokofiev K.G., Morozov A.I. The principle of sovereignty of state-legal ideology and philosophy of law // World of politics and sociology. 2019. No. 9. P. 170-178.

53. Zakhartsev S.I., Salnikov V.P. The Philosophy of Law and Legal Science. Newcastle upon Tyne: Cambridge Scholars Publishing, 2018. 270 p.

54. Zakhartsev S.I., Maslennikov D.V., Salnikov V.P. The Logos of Law: Parmenides - Hegel - Dostoevsky. The Speculative and Logical Foundations of the Metaphysics of Law. London: Europe Books. 2021. 450 p.

For citation: Zakhartsev S. I., Komarov S. A., Khabibulin A. G. Viktor Petrovich Salnikov turns 75 // Legal thought. 2021. No. 3 (123). P. 130-136.

DOI: 10.47905 / MATGIP.2021.123.3.009

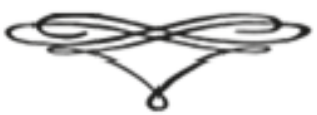




\section{ТРЕБОВАНИЯ \\ к оформмению рукописей, представияемых дия опубинковання}

1. Рукопись представляется в одном экземпмяре. Текст должен быть отпечатан через 1.5 компьютерных интервала 14 шрифтом. Страницы должны быть пронумерованы. Сноски оформляются в виде затекстовых ссылок в соответствии с библиографическими требованиями, размещаются после текста статьи под загоАовком "Библиографический список". Источники в списке располагаются в соответствии с ГОСТ Р 7.0.5-2008 "Справки по оформлению списка иитературы». При ссылке на конкретный фрагмент текста источника в отсылке указывается порядковый номер и страницы. Например:

- в тексте [8, с. 15].

- взатекстовой ссылке: Комаров С.А. Общая теория государства и права: учебник. - СПб.: Издательство Юридического института, 2012. - 520 с.

2. Объем статьи не должен превышать 8-10 машинописных страниц, а рецензии - 3 страниц.

3. Автор опмачивает расходы за редактирование, рецензирование и подготовку к публикации в размере ориентировочно 5600 руб., за превышение установленного объема - дополнительно 300 руб. за каждую страницу.

Отдельно оплачивается перевод статьи на английский язык.

Перевод рукописи статьи на ангмийский язык осуществцяется редактором-переводчиком журнала.

4. К статье должны прилагаться:

- справка об авторах (соавторах) с указанием:

a) фамилии, имени, отчества;

б) ученой степени, ученого звания;

в) должности, основного места работы;

г) контактного е-mail, домашнего и служебного адресов и телефонов;

- аннотация статьи (не менее 5 строк);

- киючевые слова (не менее 10 слов);

- рецензия от научного руководителя (дия студентов, магистрантов, аспирантов);

- справка о заимствованиях (антипмагиат)

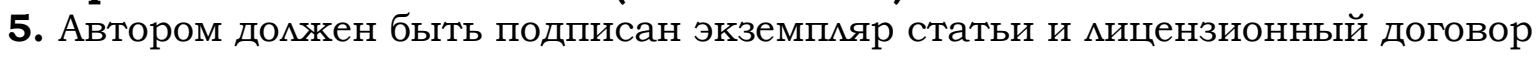
(высылается после утверждения "в печать" редакционной комлегией).

6. Пиата с аспирантов за пубцикацию не взимается (за искмючением стоимости 1 экземпляра журнала, его пересымки адресату, перевода статьи на ангАийский язык).

7. Статьи, направленные авторам на доработку, подлежат возврату в редакцию в рекомендованный срок с производственными изменениями и исправлениями в тексте (в отпечатанном виде) и с эмектронной копией.

8. Рецензии присыпаются вместе со статьями. В противном случае статьи опубликованы не будут.

9. Статьи направляются по почте (не заказной) на адрес редакции: 199106, Санкт-Петербург, В.О., УА. Гаванская, д. 3 и по эцектронной почте: lawinst-spb@mail.ru; komarova_tl@mail.ru

10. В случае несоблюдения настоящих требований по оформлению публикации редакция оставцяет за собой право ее не рассматривать. 


\section{REQUIREMENTS for Manuscripts, submitted for publication}

1. The manuscript is submitted in one copy. The text should be printed in 1.5 computer range 14 print. Pages must be numbered. Footnote out in the form of references in the endnotes according to bibliographic requirements are placed after the text of the article under the heading "References". Sources in the list are arranged in accordance with GOST R 7.0.5-2008 "Help on registration list of the literature". When referring to a specific piece of text is-sending source in the serial number and pages. For example:

- In the text [8, p. 15].

- In trans textual link: Komarov S.A. The general theory of state and law: the textbook. - St. Petersburg: Publishing House "Law Institute" (St. Petersburg), 2012. $608 \mathrm{pp}$.

2. The paper should not exceed 8-10 printed pages and reviews $\mathbf{- 3}$ pages.

3. The author pays for editing, review and preparation for the publication in the amount of 5600 rubles, for exceeding the specified amount - an additional 300 rubles for each page.

Translation of the article into English is paid separately.

Translation of the manuscript of the article into English is carried out by the editor-translator of the journal.

4. Article shall be accompanied (in electronic form):

- information about the author (co-author), indicating:

a) surname, name and patronymic;

b) scientific degree, academic rank;

c) the principal place of work, position;

d) an e-mail, home and office addresses and phone numbers;

- abstract of the article (not less than 5 lines)

- keywords (not less than 10 words)

- review

5. The author must be signed copy of the article and a license agreement (sent after the approval of "print" the editorial board). Articles graduate students must be signed by their research supervisor(s) to review the application.

6. The fee for the publication of a post-graduate students will be charged.

7. Articles, aimed authors for revision shall be returned to the editor in the recommendatory term production changes and corrections in the text (in the form of imprint) and an electronic copy.

8. Reviews are sent along with the article. Otherwise, the article will not be published.

9. Article sent by mail (not registered) to the editorial office: 199106, 3, Gavanskayast., Saint Petersburg, Russia and by e-mail: lawinst-spb@mail.ru; komarova_tl@mail.ru

10. In the case of non-compliance with these requirements by designing the publication editors reserve the right not to consider it. 


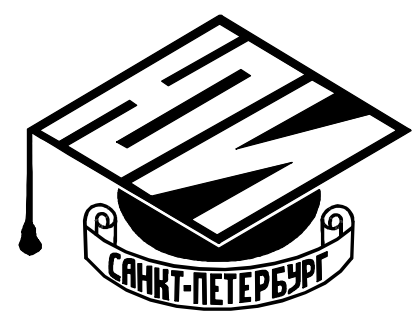

Частное образовательное учреждение высшего образования

\section{ЮРИДИЧЕСКИЙ ИНСТИТУТ}

\section{(Санкт-Петербург)}

основан в 1992 году

АИЦЕНзия

ЮРИСПРУДЕНЦИЯ

спеииализаиии:

* гражданско-правовая;

* государственно-правовая;

* международно-правовая;

* уголовно-правовая

\section{Документы:}

1. Документ об образовании

2. Шесть фотографий размером $3 \times 4 \mathrm{~cm}$

3. Свидетельства ЕГЭ по русскому языку, обществознанию, истории России

По окончании института выпускникам присваивается

степень бакалавра или магистра

(в зависимости от срока обучения)

и выдается диплом о въсшем образовании

Срок обучения:

ДНЕВНОЕ - 4 года, ЗАОЧНОЕ - $5 \Lambda$ ЕТ

ДАя Аиц со средним юридическим и высшим образованием -

ускоренный курс обучения - 3 года

\section{Ведется прием в АСПИРАНТУРУ}

по научным специамьностям:

12.00.01 - теория и история права и государства;

история учений о праве и государстве

12.00.02 - конституционное право, конституционный судебный процесс;

муниципальное право

12.00.08 - уголовное право и криминология;

уголовно-исполнитецьное право

199106, г. Санкт-Петербург,

ум. Гаванская, д. 3

(812) 325-46-25, 322-18-08

Официальный сайт: www.lawinst-spb.ru

Книжный интернет-магазин на сайте института 
Редактор, переводчик М.В. Старцева верстка И.И. Каширина

Адрес редакции: 199106, г. Санкт-Петербург, ум. Гаванская, д.3

E-mail: Legal_thought@mail.ru

Сайт: http:/ /lawinst-spb.ru/magazine http: / / matgip.ru

Темефон: (812) 325-4625; (499) 431-5806

Издатель: ЧОУ ВО «Юридический институт» (Санкт-Петербург) Адрес издателя: 199106, г. Санкт-Петербург, ул. Гаванская, д.3

Издатель: МОО «Межрегиональная ассоциация теоретиков государства и права"

Адрес издателя: 119415, Москва, Удамьцова 19-1-12

E-mail: matgip2017@yandex.ru

Выход в свет 18.09.2021. Формат 61х86 1/8.

Бумага офсетная. Печать цифровая.

Уч.-изд. м. 16,97. Уск. п.м. 10,1. Тираж 100 экз. Заказ № 103403.

Цена свободная

Отпечатано в типографии "OneBook.ru»

ООО "Сам Полиграфист"

109316, г. Москва, Волгоградский проспект, дом 42, корп. 5, "Технополис Москва" www.onebook.ru 